\title{
Neurotransmitter signaling through heterotrimeric G proteins: insights from studies in C. elegans
}

\author{
Michael R. Koelle ${ }^{\S}$ \\ Department of Molecular Biophysics \& Biochemistry, Yale University, New Haven CT 06520 \\ USA
}

\section{Table of Contents}

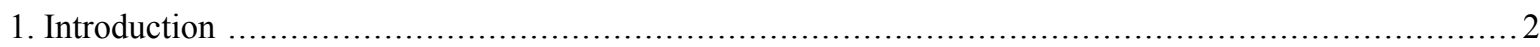

1.1. Neurotransmitters signal by gating ion channels and by activating $G$ protein coupled receptors ....2

1.2. C. elegans as a model system for studies of neural signaling …....................................... 3

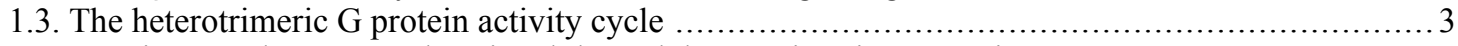

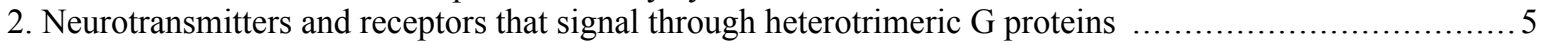

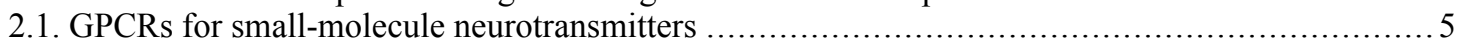

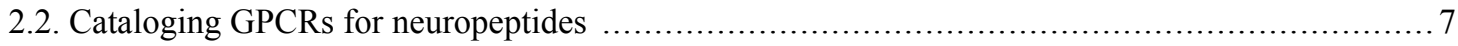

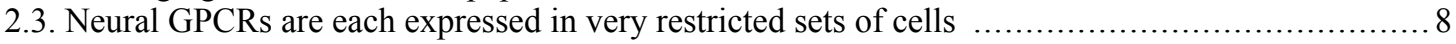

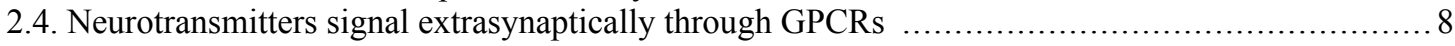

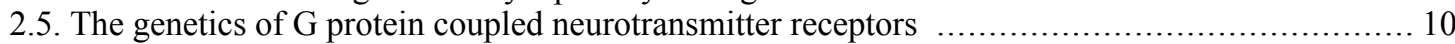

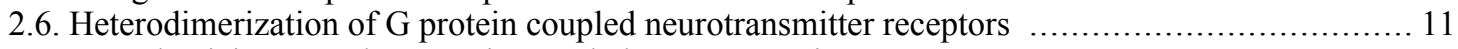

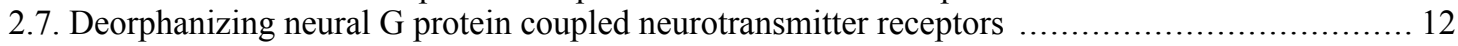

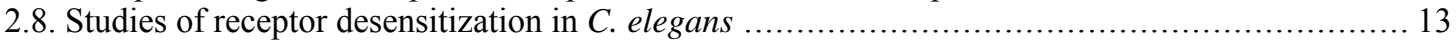

2.9. The overall landscape of neurotransmitter signaling through GPCRs ….......................... 13

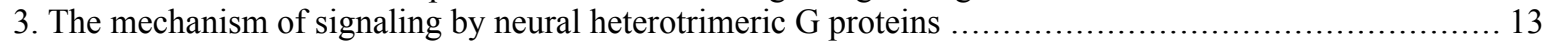

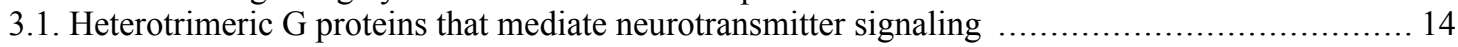

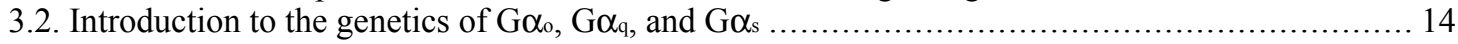

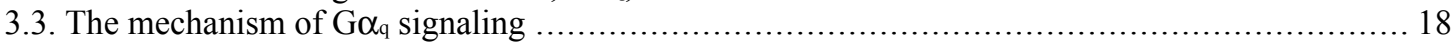

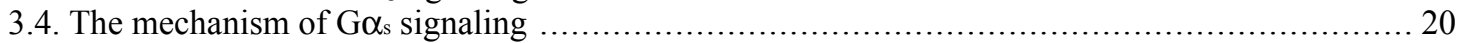

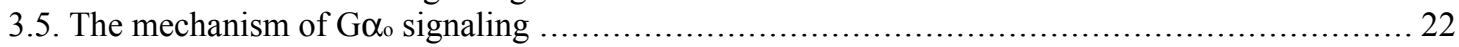

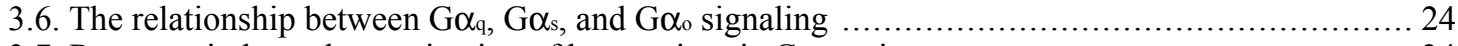

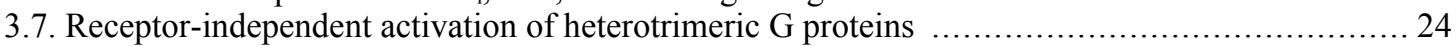

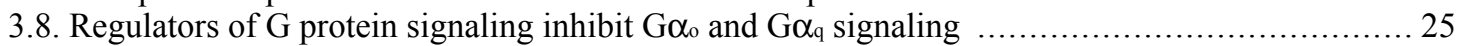

3.9. Reconciling studies of neural $\mathrm{G} \alpha$ signaling in C. elegans with those in more complex model

*Edited by Iva Greenwald Last revised February 4, 2016. Published in its final form December 11, 2018. This chapter should be cited as: Koelle M.R. Neurotransmitter signaling through heterotrimeric G proteins: insights from studies in C. elegans. (December 11, 2018), WormBook, ed. The C. elegans Research Community, WormBook, doi/10.1895/wormbook.1.75.2, http://www.wormbook.org.

Copyright: (C) 2016 Michael R. Koelle. This is an open-access article distributed under the terms of the Creative Commons Attribution License, which permits unrestricted use, distribution, and reproduction in any medium, provided the original author and source are credited.

${ }^{\S}$ To whom correspondence should be addressed. Email: michael.koelle@yale.edu 


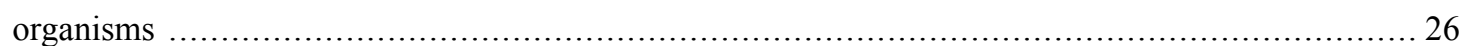

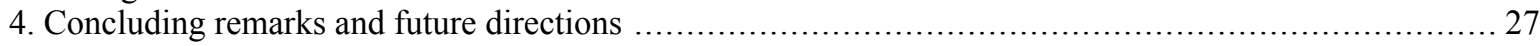

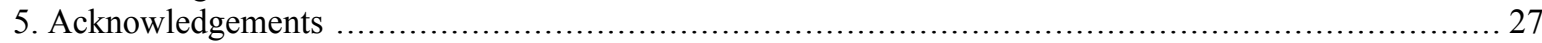

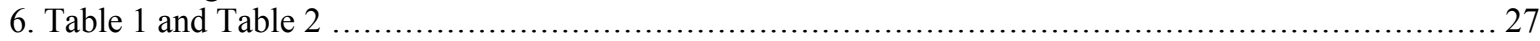

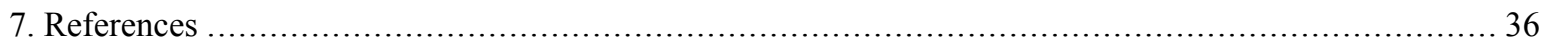

\begin{abstract}
Neurotransmitters signal via $G$ protein coupled receptors (GPCRs) to modulate activity of neurons and muscles. C. elegans has $\sim 150 \mathrm{G}$ protein coupled neuropeptide receptor homologs and 28 additional GPCRs for small-molecule neurotransmitters. Genetic studies in C. elegans demonstrate that neurotransmitters diffuse far from their release sites to activate GPCRs on distant cells. Individual receptor types are expressed on limited numbers of cells and thus can provide very specific regulation of an individual neural circuit and behavior. G protein coupled neurotransmitter receptors signal principally via the three types of heterotrimeric $\mathrm{G}$ proteins defined by the $\mathrm{G}$ alpha subunits $G \alpha_{o}, G \alpha_{q}$, and $G \alpha_{s}$. Each of these $G$ alpha proteins is found in all neurons plus some muscles. $G \alpha_{o}$ and $G \alpha_{q}$

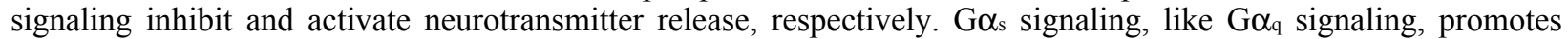
neurotransmitter release. Many details of the signaling mechanisms downstream of $\mathrm{G} \alpha_{\mathrm{q}}$ and $\mathrm{G} \alpha_{\mathrm{s}}$ have been delineated and are consistent with those of their mammalian orthologs. The details of the signaling mechanism downstream of $\mathrm{G} \alpha_{0}$ remain a mystery. Forward genetic screens in C. elegans have identified new molecular components of neural $\mathrm{G}$ protein signaling mechanisms, including Regulators of G protein Signaling (RGS proteins) that inhibit signaling, a new $\mathrm{G} \alpha_{\mathrm{q}}$ effector (the Trio RhoGEF domain), and the RIC-8 protein that is required for neuronal $\mathrm{G} \alpha$ signaling. A model is presented in which $\mathrm{G}$ proteins sum up the variety of neuromodulator signals that impinge on a neuron to calculate its appropriate output level.
\end{abstract}

\title{
1. Introduction
}

The nervous system functions through the use of neurotransmitters that act as chemical signals between cells. Small-molecule neurotransmitters such as acetylcholine, glutamate, and GABA (gamma aminobutyric acid) are released from vesicles clustered at synapses. Neuropeptides (secreted proteins of $<50$ amino acids) are released at synaptic and non-synaptic sites from a different class of vesicles, known as dense-core vesicles for their appearance in the electron microscope (Merighi et al., 2011). Certain small-molecule neurotransmitters such as serotonin can be released from either class of vesicle. All these types of neurotransmitters act on neurons and muscles to generate dynamic patterns of activity that constitute thoughts and behaviors. A principal objective in neuroscience is to understand the molecular mechanisms by which neurons and muscles respond to neurotransmitters. This objective is important to advance our basic science understanding of the brain, but also is of great medical significance since many pharmaceuticals used to treat psychiatric disorders act by mimicking, antagonizing, or altering the levels of naturally-occurring neurotransmitters (Conn and Roth, 2008), and drugs of abuse also act by altering neurotransmitter signaling (Joffe et al., 2014).

\subsection{Neurotransmitters signal by gating ion channels and by activating $G$ protein coupled receptors}

Neurotransmitters signal via two distinct classes of receptors, known within the neuroscience field as ionotropic and metabotropic receptors. Ionotropic receptors are neurotransmitter-gated ion channels, and most small-molecule neurotransmitters each have a number of such receptors (Lemoine et al., 2012). Binding of neurotransmitter to an ionotropic receptor favors channel opening, and communication between neurons using ionotropic receptors can occur in less than a millisecond (Sabatini and Regehr, 1996). Metabotropic receptors are known outside the neuroscience field as G protein coupled receptors (GPCRs) because they activate intracellular signaling proteins called heterotrimeric G proteins. All small-molecule neurotransmitters have G protein coupled receptors, as do most neuropeptides (Hall, 2004; Beaulieu and Gainetdinov, 2011; Pytliak et al., 2011; Hoyer and Bartfai, 2012; Vaidya et al., 2013; Kruse et al., 2014). An individual small-molecule neurotransmitter might have up to a dozen different GPCRs. There are over 100 neuropeptide genes in both humans and C. elegans, and each organism also has about an equal number of GPCRs that are likely to be neuropeptide receptors, as they are similar to the few $\mathrm{G}$ protein coupled neuropeptide receptors that have been characterized so far ( $\mathrm{Li}$ and $\mathrm{Kim}, 2008$; Li and Kim, 2010; Frooninckx et al., 2012; Hoyer and Bartfai, 2012). Binding of a neurotransmitter to a GPCR, as opposed to an ionotropic receptor, leads to slower and longer lasting effects. For example, GCPR signaling can involve biochemical amplification of a signal (e.g., production of a pool of second messenger) that is much slower than the 
rapid voltage changes induced by opening ion channels, and GPCR signaling can result in changes to the transcriptional program and structure of a neuron that last days or longer (Kandel, 2004). Whereas ionotropic receptors mediate signaling underlying such prosaic neural functions as the knee-jerk response, GPCRs mediate signaling underlying more poetical functions of the brain, such as feelings of pleasure and love that result from dopamine and oxytocin (Love, 2014), the psychedelic effects of hallucinogens (Fantegrossi et al., 2008), and the regulation of mood by serotonin (Donaldson et al., 2013).

\subsection{C. elegans as a model system for studies of neural signaling}

This review focuses on insights into the molecular mechanisms and biological functions of neurotransmitter signaling through GPCRs that arise from studies in the model organism C. elegans. But why study neurotransmitter signaling in the worm? Signaling through ionotropic receptors has already been studied in a sophisticated manner in other species using electrophysiological techniques to analyze ion channel activity. Such electrophysiological studies have often used model organisms such as slug, squid, leech, or crab that have large neurons easily accessible to electrodes. GPCRs activate intracellular signaling pathways that can have indirect effects on ion channel activity, and electrophysiological studies in the same model organisms have given important insights into how GPCR signaling modulates the function of neural circuits (Bailey and Kandel, 2008; Marder, 2012). However, methods for studying intracellular signaling pathways have been most highly developed outside of the neuroscience field, with the greatest successes coming from applying a combination of biochemistry and genetics, techniques not easily applied in the model organisms suited to electrophysiology. A remarkable body of biochemical studies of signaling by heterotrimeric $\mathrm{G}$ proteins, mostly in non-neuronal mammalian cells, has been in progress for decades and has resulted in many Nobel prizes (Cori and Cori, 1947; Sutherland, 1971; Krebs, 1992; Fischer 1992; Gilman 1994; Rodbell 1994; Kobilka, 2013; Lefkowitz 2013). Prior to the studies in C. elegans described in this review, neural G protein signaling had not been seriously studied using genetic approaches. Thus, despite the excellence of the body of biochemical work on $G$ protein signaling, there remained significant gaps in understanding the molecular mechanisms of this type of signaling in neurons, and also in achieving a big-picture understanding of how and why such signaling is used to control the activity of neural circuits.

As described in this review, the molecular mechanisms of neural $\mathrm{G}$ protein signaling are strongly conserved between humans and $C$. elegans, and $C$. elegans provides two advantages that complement the past electrophysiological and biochemical work on neural G protein signaling. First, the power of forward genetics in $C$. elegans has allowed new neural signaling proteins to be discovered. Second, the simplicity of the C. elegans nervous system, combined with the use of genetics, has allowed biological functions to be assigned to signaling by specific neurotransmitters acting through specific GPCRs on individual identified neurons. Enough such biological functions of neural G protein signaling have now been described that the long-elusive big-picture understanding of the whole purpose of this mode of neurotransmission is beginning to emerge.

\subsection{The heterotrimeric $\mathrm{G}$ protein activity cycle}

Here I outline the activity cycle for a generic heterotrimeric $\mathrm{G}$ protein as a prelude to diving more deeply into how specific GPCRs, G proteins, and their downstream signaling pathways regulate neural function in C. elegans. The $\mathrm{G}$ protein activity cycle proceeds through five states labeled in Figure 1. Most steps in the cycle were discovered and characterized through biochemical studies of mammalian proteins, but the RGS and RIC-8 proteins that catalyze the transitions between states 4 and 5 were discovered through studies in C. elegans and subsequently characterized in mammals. 


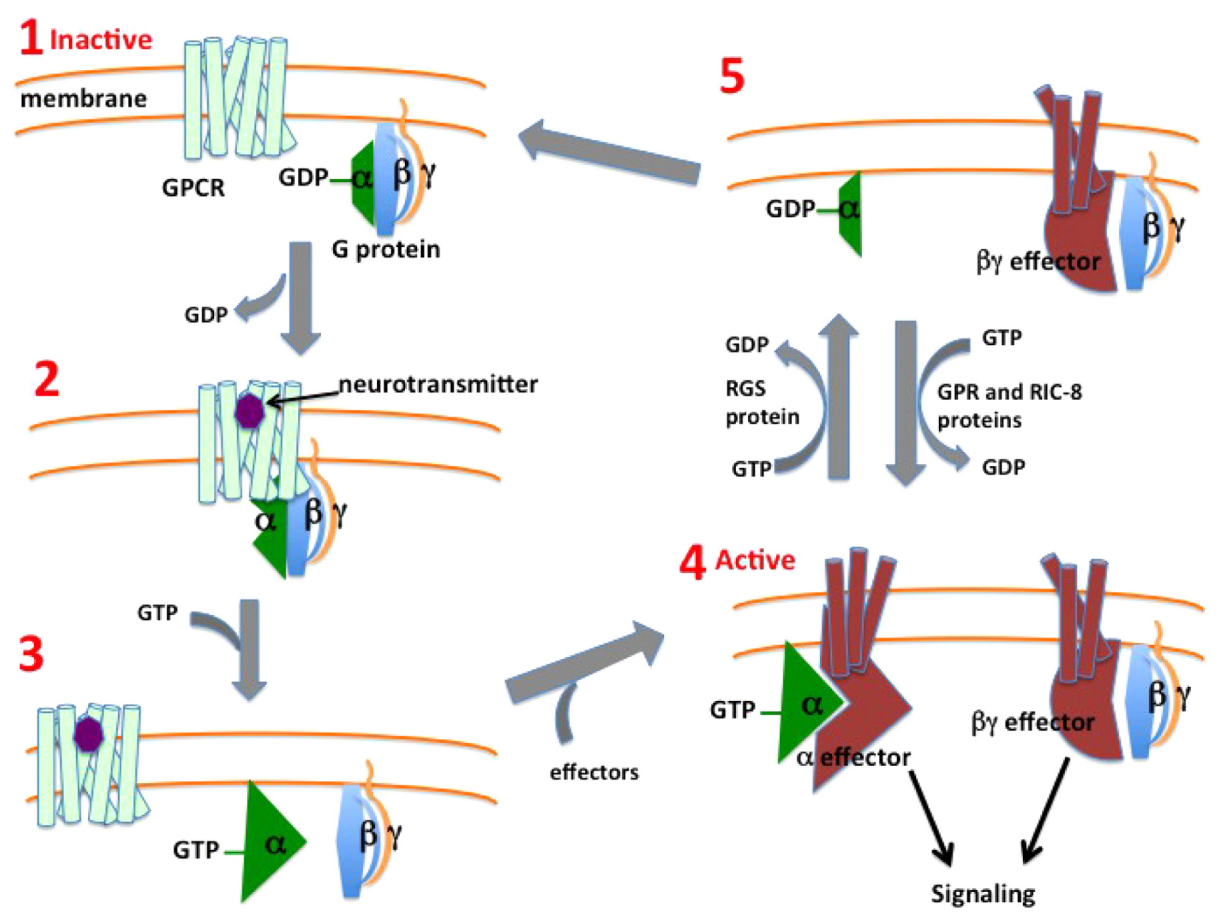

Figure 1. Activity cycle for a generic heterotrimeric G protein. In the inactive state (1), the G protein is an $\alpha \beta \gamma$ heterotrimer bound to GDP. When neurotransmitter binds the receptor (2), it assumes an active conformation that can bind the $G$ protein heterotrimer and induce a conformational change in G $\alpha$ that releases GDP. GTP can then bind the open nucleotide site (3), inducing another conformational change in G $\alpha$ that releases both the receptor and G $\beta \gamma$. The separate G $\alpha$-GTP and G $\beta \gamma$ complexes can then associate with their respective effector proteins (4), which are typically transmembrane protein complexes, activating those effectors for downstream signaling. G $\alpha$ signaling is terminated when a Regulator of G protein Signaling (RGS) protein induces

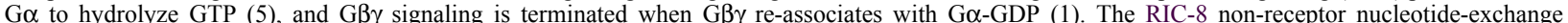
protein, working with GPR domain proteins, can prolong signaling by converting G $\alpha$-GDP (5) back to G $\alpha$-GTP (4). RIC-8 is also a chaperone required for $\mathrm{G} \alpha$ folding and stability, which may be its principal function.

\subsubsection{State 1 , the inactive state}

GPCRs are integral membrane proteins with seven transmembrane helices. Heterotrimeric G proteins have $\alpha$, $\beta$, and $\gamma$ subunits and are peripheral membrane proteins tethered to the inner leaflet of the plasma membrane by lipid modifications (Hepler and Gilman, 1992; Wedegaertner et al., 1995). The G $\alpha$ subunit changes conformation depending on whether it is bound to GDP, GTP, or no guanine nucleotide, and these conformational changes allow $\mathrm{G} \alpha$ to alter its association with other proteins (Noel et al., 1993; Coleman et al., 1994; Lambright et al., 1994; Wall et al., 1995). In its GDP-bound inactive state, $G \alpha$ is typically bound to $G \beta \gamma$ to form an inactive $G$ protein heterotrimer.

\subsubsection{State 2, activated GPCR promotes release of GDP by the $\mathrm{G} \alpha$}

Neurotransmitter binding induces conformational shifts in GPCRs that have recently been delineated by X-ray crystallographic studies (Katritch et al., 2013). GPCRs and G proteins are able to diffuse laterally due to the fluid nature of biological membranes, and a neurotransmitter-bound, activated receptor can thus collide with an inactive $\mathrm{G}$ protein heterotrimer. This interaction induces a large conformational change in G $\alpha$ that allows the release of bound GDP (Fung et al., 1981; Brandt and Ross, 1986; Rasmussen et al., 2011). The active GPCR and nucleotide-free G protein heterotrimer form a stable complex that dissociates in the next step of the G protein cycle.

\subsubsection{State 3, GTP binding induces dissociation of GPCR, G $\alpha$, and G $\beta \gamma$}

The open nucleotide-binding site on G $\alpha$ can bind GTP, which causes G $\alpha$ to undergo another conformational change that causes G $\alpha$-GTP to dissociate from both the receptor and G $\beta \gamma$ (Noel et al., 1993; Coleman et al., 1994; Lambright et al., 1994; Wall et al., 1995). The release of GDP and subsequent GTP binding by Go is referred to as "nucleotide exchange". The receptor, which remains bound to neurotransmitter, can diffuse laterally in the membrane and proceed to promote nucleotide exchange on additional $\mathrm{G}$ proteins. Thus the active receptor can function as an enzyme to catalytically promote conversion of inactive G $\alpha \beta \gamma$-GDP to the active signaling species G $\alpha-G T P$ and G $\beta \gamma$ (Ross, 2014). 


\subsubsection{State 4, G $\alpha-G T P$ and $G \beta \gamma$ signal by forming stable complexes with effectors}

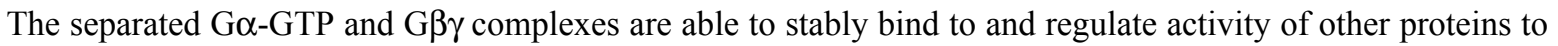
promote responses in the cell, and these other proteins are collectively termed G protein "effectors". Effectors have

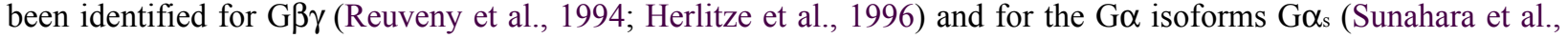

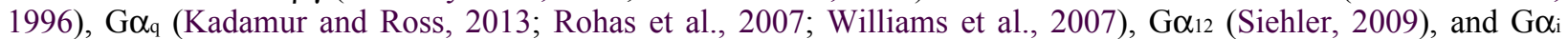
(Taussig et al., 1994). Most G protein effectors are transmembrane protein complexes. Some G protein effectors are enzymes that catalyze the production of second messengers, small molecules that can diffuse in the cell and evoke

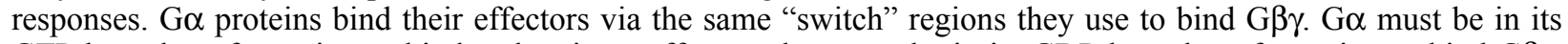
GTP-bound conformation to bind and activate effectors, but must be in its GDP-bound conformation to bind G $\beta \gamma$. Thus $\mathrm{G} \alpha$ serves as a molecular switch that alternates between an active GTP-bound state and an inactive

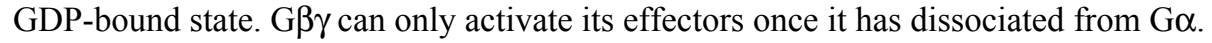

\subsubsection{State 5, inactivation of G $\alpha$ via GTP hydrolysis, and reactivation via receptor-independent nucleotide exchange}

$\mathrm{G} \alpha$ subunits of heterotrimeric $\mathrm{G}$ proteins have a slow but significant intrinsic GTPase activity, such that purified G $\alpha$ protein can hydrolyze bound GTP to GDP with a half time on the order of a few minutes. A key contribution of $C$. elegans and yeast genetics was the discovery of a class of "regulator of G protein signaling" (RGS) proteins (Koelle and Horvitz, 1996; Dohlman et al., 1996) that serve as GTPase activators for Go proteins, speeding up the hydrolysis reaction by orders of magnitude (Berman et al., 1996; Tesmer et al., 1997).

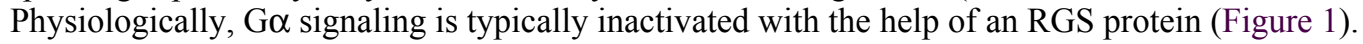

A second key contribution of C. elegans genetics was the discovery of RIC-8, a soluble protein that promotes $\mathrm{G}$ protein signaling (Miller et al., 2000), sometimes with the help of other proteins containing the G protein regulatory (GPR) motif that binds G $\alpha$ proteins (Colombo et al., 2003; Gotta et al., 2003; Srinivasan et al., 2003; Hofler and Koelle, 2011). Genetic studies in C. elegans show that GPR proteins and RIC-8 promote G protein activity, and the biochemical activities of these proteins in vitro suggest that they may do so by reactivating G $\alpha$-GDP as illustrated in Figure 1. However, studies in mammalian cells show that RIC-8, in addition to catalyzing nucleotide exchange in vitro, also acts in living cells as a chaperone to promote folding and stability of Go proteins (Gabay et al., 2011; Chan P. et al., 2013). The C. elegans genetic data are consistent with the alternative model that GPR and RIC-8 proteins are simply required for G $\alpha$ folding and stability.

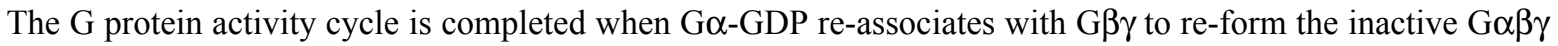
heterotrimer. $G \beta \gamma$ is sequestered in the heterotrimer so that it can no longer associate with its effectors.

\section{Neurotransmitters and receptors that signal through heterotrimeric $G$ proteins}

In this section, I describe analysis of the surprisingly large set of neurotransmitters and neural $\mathrm{G}$ protein coupled receptors present in C. elegans. Each neurotransmitter and each receptor is expressed in a very specific and limited set of neurons, and as a result each affects a very specific and limited set of behaviors. An important result from C. elegans is that a neurotransmitter can signal via a GPCR expressed on cells that are not postsynaptic to the neurons that release that neurotransmitter. Thus neurotransmitters travel through tissue to signal at sites distant from their site of release. The pattern of neurotransmitter signaling via GPCRs is thus not determined by the synaptic wiring of the nervous system, but rather by the specific expression patterns of the neurotransmitters and their GPCR receptors. The widespread nature of extrasynaptic neurotransmitter signaling forces us to expand our notion of a neural circuit to a unit consisting of neurons that function together but that may lack direct anatomical connections.

\subsection{GPCRs for small-molecule neurotransmitters}

Most major small-molecule neurotransmitters used in humans are also found in C. elegans (exceptions are norepinephrine, histamine, and possibly glycine and ATP). Table 1 and Table 2 summarize studies of a set of $28 C$. elegans GPCRs for small-molecule neurotransmitters. This includes four serotonin receptors, four dopamine receptors, three octopamine receptors, three tyramine receptors, three acetylcholine receptors, two GABA receptors that function together as an obligate dimer, three apparent glutamate receptors, and six additional predicted receptors with sequence similarity to small molecule neurotransmitter GPCRs that have yet to have ligands assigned to them or to be studied genetically. Many of these 28 GPCRs are produced in multiple isoforms via alternative splicing of their RNA transcripts 


\subsubsection{Identification of ligands for individual GPCRs}

Putative small-molecule neurotransmitter GPCRs were first identified in C. elegans as homologs of mammalian neurotransmitter receptors (e.g., Komuniecki et al., 2004). Such analyses can make predictions for the ligand that might activate a GPCR homolog, but these are weak predictions. For example, the C. elegans receptors SER-2, SER-3, and SER-6 were originally assigned their names due to similarity with serotonin receptors, but later proved experimentally to be receptors for other biogenic amine neurotransmitters (Table 1). Thus, assigning a ligand to a GPCR requires experimental evidence. Three lines of such experimental evidence are described below, and Table 1 lists which of these lines of evidence are available for each of 22 C. elegans receptors.

The first line of experimental evidence is listed in Table 1 as "binding studies". Here, a GPCR is expressed in heterologous cells inducing a binding activity in their membranes for a radiolabeled ligand. Since characterizing binding by many different radioligands is inconvenient, typically a single radioligand with binding activity is identified (e.g., ${ }^{3} \mathrm{H}-\mathrm{LSD}$, which binds with high affinity to most biogenic amine receptors), and then the ability of many unlabeled neurotransmitters and pharmaceuticals to compete off the radioligand is measured as a "Ki". Such studies measure the relative binding affinity of different ligands, but do not determine if an individual ligand is an agonist (activator) or antagonist (inhibitor) for the receptor. Based on such binding data, a GPCR is considered likely to be a receptor for the neurotransmitter that appears to bind it with highest affinity.

The second line of experimental evidence listed in Table 1 is "heterologous cell signaling". Here, a GPCR is expressed in heterologous cultured cells, typically mammalian cells or Xenopus oocytes, potential ligands are applied in the medium, and activation of downstream signaling is measured (e.g., through use of fluorescent $\mathrm{Ca}^{2+}$ indicators, electrophysiological recording of $\mathrm{G}$ protein regulated ion channels, etc.). This method allows the concentration of a ligand that gives half-maximal response $\left(\mathrm{EC}_{50}\right)$ to be measured, and can determine if a ligand is an agonist or antagonist. Further, it provides evidence for the type of $\mathrm{G} \alpha$ protein activated by the receptor (see Section 2.2.2.). Based on such heterologous cell signaling studies, a GPCR is considered likely to be a receptor for the neurotransmitter that activates it with the lowest $\mathrm{EC}_{50}$.

The third line of experimental evidence listed in Table 1 is genetic studies in $C$. elegans. In many cases, a mutant for a GPCR renders worms insensitive to the effects of a specific neurotransmitter, either applied exogenously or released endogenously via optogenetic stimulation. Another type of genetic study demonstrates that a GPCR mutant shows behavioral defects similar to those of a mutant lacking a particular neurotransmitter. Such genetic studies provide evidence that GPCR functions in vivo as a receptor for a specific neurotransmitter.

Table 1 shows that for the 22 GPCRs listed as assigned a ligand, the number of experimental lines of evidence for that assignment varies from zero to three, and the quality of each piece of evidence can also vary widely. Clearly, the more experimental evidence that is available, the more confident a ligand assignment will be.

Both C. elegans and mammals have multiple GPCRs for individual neurotransmitters. A large number of pharmaceuticals have been developed that activate or antagonize specific mammalian receptor isoforms. It is tempting to try to use $C$. elegans as a model system to investigate the functions of specific neurotransmitter receptor isoforms to better understand the actions of these important drugs. However, when the sequences of $C$. elegans neurotransmitter receptors are lined up with those of mammalian receptors, individual C. elegans receptors cannot be unambiguously assigned as orthologs of specific mammalian receptors. For example, the C. elegans serotonin receptors are more similar to mammalian serotonin receptors than they are to mammalian receptors for other neurotransmitters, but an additional C. elegans receptor (named SER-2) is also most similar to mammalian serotonin receptors in sequence and turned out be a tyramine receptor (Rex et al., 2004). By sequence analysis, the bona fide C. elegans serotonin receptors do not unambiguously match up with individual mammalian serotonin receptor isoforms. Furthermore, when C. elegans serotonin receptors are expressed in cultured cells or Xenopus oocytes, their profiles of binding and activation by drugs do not match up to the pharmacology of specific mammalian serotonin receptor isoforms (Komuniecki et al., 2004). Thus, while C. elegans generally provides an excellent model for studying small-molecule neurotransmitter signaling through $\mathrm{G}$ proteins, there are limits to the level of conservation of receptors between humans and worms.

An important issue in assigning ligands to GPCRs is the potential that a single GPCR might physiologically mediate signaling by more than one type of neurotransmitter. The heterologous cell signaling studies cited in Table 1 show that certain receptors have significant affinities for more than one biogenic amine neurotransmitter. For example, the dopamine receptor DOP-3 is activated in heterologous cell signaling studies by dopamine with an $\mathrm{EC}_{50}$ 
of $27 \mathrm{~nm}$, but also by tyramine with an $\mathrm{EC}_{50}$ of $500 \mathrm{~nm}$ (Sugiura et al., 2005). Binding studies show significant affinities for more than one biogenic amine by the receptors DOP-1, DOP-2 (Suo et al., 2002), OCTR-1 (Wragg et al., 2007), SER-2 (Rex and Komuniecki, 2002), TYRA-2 (Rex et al., 2005), and TYRA-3 (Wragg et al., 2007). Since the synaptic concentrations of released neurotransmitters are thought to go above one millimolar (Barberis et al., 2011), the high nanomolar or micromolar binding affinities of certain receptors for a secondary neurotransmitter could be biologically meaningful. Studies in C. elegans could resolve this issue. Given the complete wiring diagram in $C$. elegans, along with the known identifies of neurons that release specific neurotransmitters and that express specific GPCRs, there is the potential to identify synapses at which a GPCR is exposed to a high concentration of one of its lower-affinity ligands. Genetic analysis could then determine if this results in physiologically significant signaling.

\subsubsection{Identification of $G$ proteins activated by individual GPCRs}

Sequence comparison of $C$. elegans GPCRs to homologous mammalian GPCRs can be used to predict to which G $\alpha$ protein a particular C. elegans GPCR might couple (e.g., Wragg et al., 2007). However, a more definitive assignment requires experimental evidence. Two lines of such experimental evidence are described below, and Table 1 lists the lines of evidence for $\mathrm{G} \alpha$ protein coupling available for each of 22 C. elegans receptors.

The first line of experimental evidence is listed in Table 1 as "heterologous cell" studies. Here, a GPCR is expressed in heterologous cultured cells for ligand activation studies, as described above in Section 2.1.1. In addition to identifying an activating ligand, these studies can determine what type of G $\alpha$ protein is activated by the GPCR in heterologous cells. For example, activation of $\mathrm{Ca}^{2+}$ release generally indicates $\mathrm{G}_{\mathrm{q}}$ signaling, activation of cAMP production generally indicates $\mathrm{G} \alpha_{\mathrm{s}}$ activation, and inhibition of cAMP production and/or sensitivity to pertussis toxin generally indicates $\mathrm{G \alpha}_{\mathrm{i} / \mathrm{o}}$ activation.

The second line of experimental evidence listed in Table 1 comes from genetic studies in C. elegans. Here, a C. elegans GPCR mutant can be used to demonstrate that a receptor acts in a particular cell type to support a particular behavior, and genetic studies can similarly show that a particular $G \alpha$ protein is also required in the same cell type for the same behavior.

Table 1 shows that 20 of 22 GPCRs assigned to a ligand are also assigned coupling to a specific G $\alpha$ protein, with the number of experimental lines of evidence for that $G \alpha$ assignment varying from zero to two. G $\alpha$ assignments from heterologous cell studies generally agree with assignments from $C$. elegans genetics in cases where both lines of evidence are available, bolstering confidence in assignments from the many cases with only one line of evidence. An interesting case is that of the dopamine receptor DOP-2, which was assigned to G⿰ $\alpha_{\mathrm{i} / \mathrm{o}}$ in heterologous cell studies, and for which C. elegans genetics suggests that three different $\mathrm{G \alpha}_{\mathrm{o}}$-related $\mathrm{G} \alpha$ proteins may mediate DOP-2 signaling in worms (Suo et al., 2003; Suo et al., 2009; Correa et al., 2012; Pandey and Harbinder, 2012; Mersha et al. 2013).

\subsection{Cataloging GPCRs for neuropeptides}

At present at least 119 C. elegans genes encoding over 250 neuropeptides have been cataloged ( $\mathrm{Li}$ and Kim, 2008; $\mathrm{Li}$ and Kim, 2010). Identifying the receptors for all these neuropeptides is a major challenge. Of the $>1,000$ putative GPCRs encoded in the C. elegans genome, most are chemosensory receptors, and a much smaller subset are likely to be neuropeptide receptors. For tables itemizing these receptors, I refer readers to several recent reviews that have cataloged the likely $C$. elegans neuropeptide receptors by looking for GPCRs most similar to known neuropeptide receptors (Altun, 2011; Frooninckx et al., 2012; The neuronal genome of Caenorhabditis elegans). These cataloging efforts generally predict about 150 genes encoding neuropeptide receptors, with individual genes often producing a number of differentially spliced isoforms.

Only a relatively small number of putative neuropeptide receptors have been assigned as receptors for specific neuropeptide(s) - one recent count put the number of such "deorphanized" neuropeptide receptors at 23 (Frooninckx et al., 2012). The quality of the data varies for each receptor, but a definitive assignment of a peptide to a receptor should include data showing the peptide binds the receptor with high affinity and specificity, as well as C. elegans genetic data demonstrating that the peptide functions via the receptor to regulate a specific behavior. An example of such a definitive assignment is work showing that the sensory BAG neurons release two different peptides encoded by the $f l p-17$ gene which then act via the EGL-6 receptor on the HSN motor neuron to inhibit egg-laying behavior (Ringstad and Horvitz, 2008). 
Can C. elegans neuropeptides or neuropeptide receptors be matched up with mammalian orthologs? In the case of the neuropeptides, the sequences are so short that there just is not enough information content in them to make such an analysis possible. In the case of the receptors, their information-rich sequences do allow such an analysis. Mammalian neuropeptide receptors can be broken down into several subfamilies based on sequence relationships, and many worm receptors can similarly be fitted into the same families (Altun, 2011; Frooninckx et al., 2012; The neuronal genome of Caenorhabditis elegans). Most C. elegans putative neuropeptide receptors cannot be definitively assigned as orthologs of specific mammalian receptors simply based on sequence analysis. However, based on sequence similarity as well as additional functional data, some worm receptors have been described as models for specific mammalian receptors. Thus C. elegans NPR-1 is similar to the mammalian neuropeptide Y receptor (de Bono and Bargmann, 1998), C. elegans PDFR-1 is similar to the Drosophila pigment dispersing factor receptor and mammalian vasoactive peptide and calcitonin receptors (Janssen et al., 2008), and C. elegans NPR-17 is similar to mammalian opioid receptors (Cheong et al., 2015).

\subsection{Neural GPCRs are each expressed in very restricted sets of cells}

An important result from analysis of $G$ protein coupled neurotransmitter receptors in C. elegans is that each receptor tends to be expressed on a small number of specific neurons, allowing that receptor to mediate very specific effects on behavior. C. elegans hermaphrodites have just 302 neurons, which, due to symmetries and repeated structures in the anatomy, can be classified into 118 types. Each neuron can be identified by its unique position and morphology within the animal. Further, all the synaptic connections of each neuron with other neurons and muscles have been mapped, making $C$. elegans the only animal for which a complete neural wiring diagram is available (White et al., 1986). Because of these features, identifying all the specific neurons that express a neurotransmitter and its receptor is uniquely possible in C. elegans, and this information, once obtained, can be interpreted using the wiring diagram to obtain unique insights into neural signaling. In this section I begin a discussion of this area of investigation.

The expression patterns of a significant subset of $C$. elegans neural GPCRs have been studied. These experiments generally involve creating transgenic worms in which the promoter and other regulatory sequences for a GPCR gene are used to drive expression of the green fluorescent protein (GFP), and specific cells expressing GFP are identified by fluorescence microscopy. Data for the expressions patterns of 22 GPCR receptors for small-molecule neurotransmitters are summarized in Table 2, and expression patterns for 27 of the 150 putative neuropeptide receptors are also available (The neuronal genome of Caenorhabditis elegans). The quality and completeness of the work varies greatly for each receptor. In some cases, only relatively short promoter regions were used to construct the GFP reporter transgenes, raising questions as to whether the results obtained fully represent the expression patterns of the endogenous GPCR genes. In other cases, only a cursory analysis of the fluorescently labeled cells is presented, with little or no attempt to identify the GFP-expressing cells.

Despite these caveats, an important generalization can be made about the expression patterns of neural GPCRs: an individual neurotransmitter receptor type tends to be expressed in a limited set of specific cells. This can be illustrated with examples from receptors for which relatively high-quality expression data are available and which typify the results obtained with other receptors. A GFP reporter for the EGL-6 neuropeptide receptor was expressed in just three types of neurons (HSN, SDQ, DVA) and one type of glial cell (GLR) (Ringstad and Horvitz, 2008). A GFP reporter for the NPR-1 neuropeptide receptor was expressed in approximately 20 neuron cell types (Coates and de Bono, 2002). A reporter for the NPR-4 neuropeptide receptor was expressed in five neuron types, the intestine, and the rectal gland cell, while a reporter for the NPR-5 neuropeptide receptor was expressed 13 neuron types and in all body wall muscles (Cohen et al., 2009). Expression patterns of G protein coupled receptors for small-molecule neurotransmitters (Table 1) show similar characteristics to those seen in the above examples of neuropeptide receptors - each receptor is typically expressed in a limited number of neuron types plus sometimes additional non-neuronal cell types. For example, a reporter for the TYRA-2 tyramine receptor is expressed in about 14 neuron types (Rex et al., 2005). Reporters for the SER-2 tyramine receptor are expressed in a total of 24 neuron types, plus body wall muscles, pharyngeal muscles, and the excretory gland (Tsalik et al., 2003).

\subsection{Neurotransmitters signal extrasynaptically through GPCRs}

The predominant model of neural signaling has been that synapses, specialized physical connections between neurons, are the sites of neurotransmitter signaling between neurons. A presynaptic neuron releases neurotransmitter from vesicles clustered at a presynaptic terminus, flooding the narrow synaptic cleft with neurotransmitter, which binds to neurotransmitter receptors clustered on the postsynaptic membrane. The idea that synapses are central to 
understanding neural function inspired the landmark achievement of mapping all the synaptic connections in the $C$. elegans nervous system (White et al., 1986), and is behind current efforts, for example within the BRAIN initiative, to map synaptic connections within more complex nervous systems (Jorgenson et al., 2015).

While ionotropic neurotransmitter signaling may typically be restricted to synapses, studies in C. elegans provide ample evidence that neurotransmitter signaling through $G$ protein coupled receptors may be predominantly extrasynaptic. The concept of extrasynaptic neurotransmission (also called volume transmission) originated in 1986 based on studies of mammalian brain (Agnati et al., 1986). Since then, many studies in mammalian brain demonstrated the release of neurotransmitters from extrasynaptic sites, the ability of neurotransmitters to diffuse through the extracellular space, and the localization of G protein coupled neurotransmitter receptors to extrasynaptic sites (Agnati et al., 2010). Indeed, given the submicromolar affinities of many GPCRs for their neurotransmitter ligands (see Table 1 for examples), it would make little sense for such receptors to function at synapses where neurotransmitter concentrations can rise to the millimolar level (Barberis et al., 2011) and may never be reduced to low enough concentrations to allow high-affinity receptors to become unliganded. Despite this evidence, it has been difficult to provide genetic evidence demonstrating the functional significance of extrasynaptic signaling in mammalian brain. In contrast, $C$. elegans is ideally suited to such work. In this system, it is possible to use rigorous genetic experiments to define the specific neurons that release a neurotransmitter to induce a particular behavioral response, and to also define the specific neurons that express the $G$ protein coupled receptor that functionally receives the neurotransmitter signal to execute the response. Remarkably, results of such analyses show over and over again that the neurotransmitter releasing neuron and the receptor-expressing receiving neuron are not synaptically connected. Ironically, the complete synaptic wiring diagram of the $C$. elegans nervous system has thus been the key tool for demonstrating that synapses are often not needed to mediate neurotransmitter signaling via $\mathrm{G}$ protein coupled receptors. Here I summarize the evidence for extrasynaptic neurotransmitter signaling in C. elegans.

\subsubsection{Neurotransmitters are released from extrasynaptic sites}

Neuropeptides and some small-molecule neurotransmitters are released from dense-core vesicles, which are distinct from the small-clear vesicles clustered at presynaptic termini. In C. elegans neurons that make synapses dense-core vesicles are excluded from the synaptic active zones where synaptic vesicles are released, although many are localized nearby (Hammarlund et al., 2008). Furthermore, C. elegans, like the human brain, has specialized neuroendocrine cells that synthesize and release neurotransmitters but that do not form synaptic connections with any other cells. The uv1 neuroendocrine cells release tyramine and neuropeptides to inhibit egg-laying behavior (Jose et al., 2007), and the NSM neuroendocrine cells release serotonin to regulate locomotion (Sawin et al., 2000; Gürel et al., 2012). The extrasynaptic neurotransmitter release sites of NSM have been studied in some detail (Nelson and Colón-Ramos, 2012). The documented functions of neurotransmitter release from uv1 and NSM provide one set of evidence that neurotransmitters do signal extrasynaptically. Some additional cells in C. elegans do not form any synapses, yet express neuropeptide genes, so any functions of peptides secreted from these cells must also be extrasynaptic. Cells in this category include the CAN cell, intestinal cells, muscle cells, and hypodermal cells (White et al., 1986; Li and Kim, 2008; Li and Kim, 2010).

\subsubsection{Neurotransmitters can signal through GPCR receptors on cells not postsynaptic to their release sites}

The specific $C$. elegans neurons that synthesize and release individual small molecule neurotransmitters or neuropeptides have been mapped in considerable detail (see WormBook chapter GABA; Rand, 2007; Chase and Koelle, 2007; Li and Kim, 2008; Li and Kim, 2010; Jafari et al., 2011; Serrano-Saiz et al., 2013; Periera et al., 2015). Thus when the expression pattern of a $G$ protein coupled receptor for a specific neurotransmitter is determined, we can use the synaptic wiring diagram of $C$. elegans to see if the cells that produce that neurotransmitter are presynaptic to the cells that express its receptor. In many cases, the answer is no.

G protein coupled receptors for small-molecule neurotransmitters are expressed on cells not postsynaptic to neurons that release the corresponding neurotransmitter. This was first noted for the dopamine receptors DOP-1 and DOP-3, which are expressed, among other places, on ventral cord motor neurons (Chase et al., 2004). Dopamine is released from exactly three types of neurons in C. elegans, and none of these neurons make synapses onto the ventral cord motor neurons. Genetic studies show that dopamine regulates locomotion via the DOP-1 and DOP-3 receptors, and the locomotion defects of $d o p-1$ and $d o p-3$ mutants can be rescued be re-expressing the receptors specifically in ventral cord motor neurons (Chase et al., 2004). These experiments rigorously demonstrate that dopamine receptors are not only found on cells distant from dopamine release sites, but that they also function to mediate dopamine signaling in these distant cells. 
Since those initial studies of dopamine signaling, similar experiments have demonstrated extrasynaptic signaling by other small-molecule neurotransmitters. One striking case is that of the neurotransmitter tyramine, which is released from only the neuroendocrine uv1 cells (which make no synapses) and from the RIM interneuron, which makes synapses only onto four other types of neurons and onto neck muscles (White et al., 1986). When $C$. elegans is touched on the head, tyramine released from RIM mediates a complex escape response. One aspect of this response is mediated by tyramine signaling at synapses from RIM onto neck muscles using an ionotropic receptor (Pirri et al., 2009). However, another aspect of the escape response is mediated by tyramine signaling from RIM through a G protein coupled receptor. This GPCR, SER-2, is expressed on GABAergic motor neurons, which are not post-synaptic to RIM, and defects in the escape response seen in ser-2 mutants are rescued by cell-specific re-expression of ser-2 in GABAergic motor neurons, demonstrating that SER-2 acts in these neurons to mediate extrasynaptic signaling by tyramine that originates from RIM (Donnelly et al., 2013).

There have now been similar genetic demonstrations that neuropeptides signal onto cells not postsynaptic to the neurons that release them. For example, FLP-17 neuropeptides are released from BAG sensory neurons and signal via the EGL-6 neuropeptide receptor on the HSN motor neurons, which are not postsynaptic to BAG, to inhibit egg laying (Ringstad and Horvitz, 2008). The C. elegans defecation motor program is coordinated by NLP-40 peptides released from intestinal cells, which being non-neuronal make no synapses, and these NLP-40 peptides signal onto GABAergic motor neurons via the AEX-2 peptide receptor (Wang et al., 2013). Beyond these rigorous genetic demonstrations that specific peptides signal extrasynaptically via particular neuropeptide receptors, there are additional data showing that some neuropeptide receptors are expressed on cells that do not receive any synapses, so that any signaling they mediate on these cells must be extrasynaptic. These receptor-expressing cells include intestinal, hypodermal, and glial cells (The neuronal genome of Caenorhabditis elegans).

\subsection{The genetics of $G$ protein coupled neurotransmitter receptors}

Null mutants or RNAi knockdowns for many C. elegans G protein coupled neurotransmitter receptors have been analyzed, and the main finding is that phenotypic defects are very hard to detect in them. Most of the time no defects are observed, and the few mutant phenotypes that have been described for neural GPCRs are typically not gross behavioral defects obvious upon inspection of individual animals, but rather narrow behavioral defects detectable only when populations of worms are put through specific phenotypic assays.

An initial effort at identifying neural GPCR phenotypes used RNAi to knock down expression of $60 \mathrm{G}$ protein coupled neurotransmitter receptors (Keating et al., 2003) and simply looked for uncoordinated movement or defects in reproduction. Knockdown of seven of the receptors had detectable effects on the frequency and/or amplitude of body bends, while knockdown of five receptors had some effect on the production of progeny. Later large-scale RNAi screens for genes that affect acetylcholine release/signaling identified hits in five GPCR genes, of which three were validated using genetic knockout mutations (Sieburth et al., 2005; Vashlishan et al., 2008). It is difficult to interpret some of these RNAi results: not all the defects seen with RNAi were reproduced with genetic mutations, the RNAi results did not always reproduce in different labs, and the phenotypes that were observed have not been characterized in much detail. Negative results from RNAi for GPCRs are also difficult to interpret since gene expression in $C$. elegans neurons is not always efficiently knocked down by RNAi, even in mutant backgrounds that enhance neuronal RNAi (Poole et al., 2011).

Mutations in genes encoding GPCRs have almost never been generated in forward genetic screens, despite the large number of GPCR genes in the worm genome. Since Brenner's first screen for uncoordinated mutants (Brenner, 1974), C. elegans mutants for thousands of genes have been generated in genetic screens, including a large number with defects in neural structure and/or function. Included in this trove are many mutants for heterotrimeric G proteins and other signaling proteins that act downstream of neural GPCRs (Perez-Mansilla and Nurrish, 2009), making the absence of neural GPCR mutants even more conspicuous.

Considering the few neural GPCR mutants that have arisen in forward genetic screens is instructive. The EGL-6 neuropeptide receptor was identified by a rare gain-of-function mutation that inhibits egg laying (by increasing EGL-6 signaling), yet knockout mutations of EGL-6 do not produce detectable egg-laying defects (Ringstad and Horvitz, 2008). Loss-of-function mutations in G protein coupled serotonin and dopamine receptors have arisen in forward genetic screens, but in these cases the phenotype screened for was resistance to the paralysis induced by applying these neurotransmitters to worms at high concentrations (Chase et al., 2004; Gürel et al., 2012). These mutants do not have obvious behavioral defects when animals are not bathed in a neurotransmitter, although defects have been detected when populations of mutant animals are put through very specific behavioral assays 
known to depend on serotonin or dopamine. There is perhaps only a single example of a neural GPCR for which loss-of-function mutants have been recovered from a forward genetic screen and for which the mutant phenotype is easily observable in single animals: mutants lacking AEX-2, the receptor for NLP-40 neuropeptides, are defective in the expulsion step of defecation (Mahoney et al., 2008; Wang et al., 2013).

C. elegans mutants for many $G$ protein coupled neurotransmitter receptors are available as a result of large-scale efforts to produce gene knockouts for all C. elegans genes (C. elegans deletion mutant consortium, 2012). However, phenotypic defects have been described for only a small subset of these GPCR mutants. The cases in which phenotypic defects have been detected have generally come when either the neurotransmitter that activates the GPCR was known, so that specialized assays for behaviors dependent on that neurotransmitter could be assayed for defects, or in cases in which the expression pattern of the GPCR was known, so that specialized assays for behaviors dependent on neuron(s) that express the receptor could be tested for defects. An example that illustrates both strategies comes from the work of Harris et al. (2009), which analyzed how C. elegans backs away from the odor of dilute octanol, a response known to depend on both the neurotransmitter serotonin and on a neural circuit containing specific sensory neurons and interneurons. This information was used to focus in on two $G$ protein coupled serotonin receptors, one expressed in the interneurons, another in the sensory neurons, and further experiments showed that knockouts and knock downs of these receptors resulted in specific behavioral defects in response to octanol. The two serotonin receptors studied by Harris et al. (2009) are part of the set of 22 receptors for small molecule neurotransmitters listed in Table 2, which are the most intensively studied GPCRs in C. elegans. As shown in Table 2, at this point mutant defects have been described for 20 of these receptors. The situation is less encouraging in the case of neuropeptide receptors, with mutant phenotypic defects described for only a few out of this large set of $\sim 150$ receptors.

Considering the totality of available genetic studies of C. elegans $\mathrm{G}$ protein coupled neurotransmitter receptors, it appears that the knockout phenotypes for these proteins are generally so narrow that they will not be easily detected. Because individual receptors are expressed in only a few types of neurons, it is reasonable to expect that just the very specific behaviors affected by those neurons will be affected, and that specialized behavioral assays will be required to detect these defects. Another possible reason that GPCR mutant phenotypic defects are rarely detected could be that the large family of GPCRs contains many functionally redundant receptors, such that knocking out one receptor will not give obvious defects unless its redundant partners are also knocked out simultaneously. Several examples support the idea that neurotransmitter receptors can function redundantly. Two serotonin receptors appear to be co-expressed on the vulval muscles and both appear to promote activity of these muscles (Hapiak et al., 2009). Serotonin released from the NSM neurosecretory cells inhibits locomotion, and two different serotonin receptors expressed on largely non-overlapping sets of neurons redundantly mediate this effect (Gürel et al., 2012). Neuropeptides encoded by FLP-18 modulate locomotion, and three different receptors, NPR-1, NPR-4, and NPR-5, expressed in different sets of cells, redundantly mediate these effects of FLP-18 (Stawicki et al., 2013). FLP-18 signaling is quite complex, because other behavioral effects of FLP-18 peptides are mediated non-redundantly by NPR-1, and for these effects FLP-18 and FLP-21 neuropeptides both seem to activate NPR-1 (Choi et al., 2013). If such complex functional relationships between neurotransmitters and receptors are widespread, this will make assigning functions to receptors using knockout mutations very challenging.

A tool that may prove generally useful in genetically characterizing redundant or subtle GPCR functions is transgenic overexpression of GPCRs. One example comes from studies of the EGL-6 neuropeptide receptor. Loss-of-function mutants for EGL-6 do not result in obvious defects under standard lab growth conditions. However, using a transgene carrying many copies of egl-6 genomic DNA to presumably overexpress the receptor does result in an obvious egg-laying defective phenotype, apparently due to increased activation of the overexpressed EGL-6 receptor by the FLP-10 and FLP-17 neuropeptides (Ringstad and Horvitz, 2008). Another example comes from studies of the NPR-17 neuropeptide receptor. NPR-17 mediates an effect of NLP-3 peptides to modulate how $C$. elegans backs away from aversive stimuli, and a transgene carrying many copies of the $n p r-17$ gene causes a gain-of-function phenotype opposite that of an $n l p-3$ or $n p r-17$ knockout, and that depends on the presence of a wild-type NLP-3, suggesting that the overexpressed NPR-17 receptor causes increased NPR-17 signaling (Harris et al., 2010). If transgenically overexpressing a GPCR is generally able to induce gain-of-function phenotypes, this could be a valuable approach for identifying subtle or redundant functions of GPCRs.

\subsection{Heterodimerization of $\mathrm{G}$ protein coupled neurotransmitter receptors}

A major area of current research on mammalian GPCRs concerns the homo- and hetero-oligomerization of these receptors (González-Maeso, 2011). It appears that in many cases, two different types of GPCRs can exist and function in vivo as a heterodimeric complex, and that a heteromeric receptor can have very different signaling 
properties than homomers of its subunits, including the ability to bind to different ligands. While GPCR heteromerization has so far been studied mainly using biochemical and biophysical methods, genetic analysis has much to contribute to understanding the physiological significance of this phenomenon. Heteromerization also potentially vastly complicates the challenge of understanding GPCR function: if $C$. elegans has $\sim 150 \mathrm{G}$ protein coupled neurotransmitter receptor genes, how many types of heteromeric GPCRs might actually be the functional units in vivo?

There have so far been only a few efforts to analyze GPCR heteromer function in C. elegans. One example is that of the $G$ protein coupled receptor for the neurotransmitter GABA. In mammals this GABAв receptor is an obligate heteromer between the GABAB1 and GABAв2 subunits (Kaupmann et al., 1998). C. elegans has orthologs of each subunit, known as GBB-1 and GBB-2, respectively. Knockouts of either GBB-1 or GBB-2 can block all G protein coupled responses to GABA in worms (Schultheis et al., 2011), and GBB-1 and GBB-2 act together to alter responses to the drug aldicarb (Dittman and Kaplan 2008; Vashlishan et al., 2008), consistent with the idea that the GABAв receptor is an obligatory heterodimer in worms just as it is in mammals. A second example comes from studies of signaling onto sensory neurons, not by a neurotransmitter, but by the mixture of small molecules known as ascarosides that collectively make up the worm dauer pheromone. The functional receptor for the specific ascaroside isoform ascr\#2 appears to be a heteromer of the GPCRs DAF-37 and DAF-38 (Park et al., 2012). ascr\#2 binds directly to DAF-37, and DAF-37 is essential for response to ascr\#2 but is not involved in the response to other ascaroside isoforms. Genetic studies show that DAF-38 assists but is not essential for response to ascr\#2, and similarly assists response to other ascaroside isoforms that do not signal through DAF-37, suggesting DAF-38 may heteromize with and assist signaling by a several different GPCRs that bind directly to different ascaroside isoforms. These studies demonstrate the potential of $C$. elegans genetic studies to sort out the intricacies of how GPCR subunits function together as heteromeric receptors in vivo.

\subsection{Deorphanizing neural $G$ protein coupled neurotransmitter receptors}

One of the principal issues in studying neural GPCRs is identifying the specific neurotransmitters that activate them. At this point, 22 of 28 GPCRs encoded in the worm genome that seem likely to be receptors for small-molecule neurotransmitters have been matched with their activating ligands (Table 1), but about $85 \%$ of the $\sim 150$ putative neuropeptide receptors remain "orphans", that is receptors with unknown activators (Frooninckx et al., 2012).

The general strategy to deorphanize neuropeptide receptors is to express them in heterologous cells, to apply synthetic versions of each neuropeptide encoded in the genome, and to test which specific peptides can activate receptor signaling. There are a number of cell types and signaling assays that have been used successfully for this purpose (Mertens et al., 2004). This strategy has been applied to a number of $C$. elegans neuropeptide receptors, for example, EGL-6 (Ringstad and Horvitz, 2008) and NPR-1 (Rogers et al., 2003 Kubiak et al., 2003). The reverse strategy has also been used, screening through a set of $C$. elegans neuropeptide receptors to identify those that can be activated by a particular neuropeptide of interest (Cohen et al., 2009). The results of receptor deorphanization experiments are complex: often a single receptor can be activated by multiple different peptides, the same peptides can activate multiple different receptors, the results can vary depending on the cell type and assay system used, and the $\mathrm{EC}_{50}$ values measuring the potencies with which peptides activate receptors vary from the nanomolar to micromolar ranges (Peymen et al., 2014).

C. elegans provides the opportunity to analyze mutants for the receptors and peptides putatively matched by such deorphanizing experiments to determine if they actually function together in vivo. Genetic approaches can also be used to match peptides and their receptors, for example, screening RNAi knockdowns of many neuropeptide genes to find those that phenocopy a particular orphan receptor mutant (Cohen et al., 2009). Such genetic studies have generated results that are similar in complexity to those from using signaling assays in cultured cells for receptor deorphanization. Thus it appears that in vivo individual receptors can be activated by multiple peptides and individual peptides can act through multiple receptors (Choi et al., 2013; Stawicki et al., 2013).

The gold standard in matching neuropeptides with receptors is to combine studies of receptor activation by purified peptides in cultured cells with genetic studies in C. elegans. For the most part, it has been possible to achieve consistent results between the two approaches, generating strong confidence in the results, although there have been occasional puzzling exceptions (Cheong et al., 2015). Overall, the data matching neuropeptides to their cognate receptors remains sparse and we have a long way to go to fully match up these signaling molecules. 


\subsection{Studies of receptor desensitization in C. elegans}

In order for signaling by an activated GPCR to terminate, the receptor must eventually be inactivated. One mechanism for terminating receptor activity is to clear neurotransmitter from the extracellular space so that it no longer remains bound to the receptor. There are enzymes that degrade neurotransmitters and transporters that take them back up into cells that function for this purpose (Zimmerman and Soreq, 2006; Kanner and Zomot, 2008). Another mechanism for terminating signaling involves G protein coupled receptor kinases (GRKs) that specifically recognize and phosphorylate active GPCRs, and arrestin proteins that bind phosphorylated receptors. Phosphorylation and arrestin binding can block the ability of receptors to activate G proteins and also cause cells to internalize receptors from the cell surface, down-regulating signaling (Kohout and Lefkowitz, 2003). These mechanisms, referred to as receptor desensitization, have been extensively studied in mammalian cells. Studies in $C$. elegans of GRK and arrestin homologs have identified specific functions of these proteins in sensory neurons (Fukuto et al., 2004; Palmitessa et al., 2005, Pereira and van der Kooy, 2012; Singh and Aballay, 2012), but have so far failed to show any striking effects of GRK or arrestin on neurotransmitter signaling in the rest of the nervous system.

\subsection{The overall landscape of neurotransmitter signaling through GPCRs}

It is interesting to extrapolate from the existing data on $C$. elegans $\mathrm{G}$ protein coupled neurotransmitter receptors to consider what the overall landscape of neural signaling through GPCRs may look like. If we imagine that the $\sim 175$ neural GPCRs in C. elegans are each expressed on average in 10 of the 118 neural cell types, then a typical neuron would express about 15 GPCRs, about two of which might be small-molecule neurotransmitter receptors, with the remainder being neuropeptide receptors. This typical neuron would then face the task of simultaneously sensing the levels of $\sim 15$ neurotransmitters in its extracellular space and executing appropriate responses to the dynamic mix of these signals it receives over time. All the GPCRs in this typical neuron may signal through about three types of $\mathrm{G} \alpha$ proteins, which do not act separately but rather collaborate to modulate neurotransmitter release from the neuron (see Section 3). Thinking about neurotransmitter signaling through GPCRs this way, it does not make sense to consider the action of a single neurotransmitter at a time, which is the way that we currently investigate neural signaling. Rather, it may be more appropriate to investigate how a single neuron computes appropriate responses to the entire mix of neurotransmitters in its environment. A prerequisite to such an investigation would be to know all the GPCRs that are present on that neuron, and we currently do not have that information for even a single C. elegans neuron.

Perhaps the most striking result from analysis of $C$. elegans neural GPCRs is that neurotransmitters signal extrasynaptically through these receptors. Thus neurons that have no physical connections can signal each other and work together to control specific behaviors. The predominant model for understanding nervous system function has been that the functional ensembles of neurons that control thoughts and behaviors are circuits defined by the synaptic connections between the neurons in the ensemble. We have had the synaptic wiring diagram for the $C$. elegans nervous system for almost 30 years (White et al., 1986) and it has proven insufficient to allow us to understand the neural control of behaviors in this organism. Now that we understand the widespread nature of extrasynaptic neurotransmitter signaling, we need to expand our understanding of a neural circuit to be a functional ensemble of neurons that signal each other but that may lack direct anatomical connections. The patterns of signaling via GPCRs are not determined by the synaptic wiring of the nervous system, but rather by the specific expression patterns of neurotransmitters and their GPCR receptors. Thus to help understand neural circuit function, we need to supplement the existing synaptic wiring diagram with an additional diagram in which the specific cells that express each neurotransmitter and its cognate receptor(s) are defined. This goal, while ambitious, is potentially achievable in the C. elegans system, perhaps aided by new cell-specific RNAseq technologies (Spencer et al., 2014).

\section{The mechanism of signaling by neural heterotrimeric G proteins}

In this section, I focus on genetic studies in $C$. elegans of signaling by the neural $G$ proteins $G \alpha_{o}, G \alpha_{q}$, and $\mathrm{G} \alpha$ s that mediate signaling by $\mathrm{G}$ protein coupled neurotransmitter receptors. The $\mathrm{G}$ proteins themselves and their downstream signaling pathways are strongly conserved comparing mammalian brain and C. elegans. Genetic studies in C. elegans show that all three types of $\mathrm{G} \alpha$ proteins signal to regulate neurotransmitter release. C. elegans genetic screens have been used to discover new signaling molecules that regulate neural $G$ protein signaling, including Regulators of G protein Signaling (RGS proteins) that help terminate signaling, the RIC-8 protein that is required for signaling, and a new $\mathrm{G} \alpha_{q}$ effector (Trio's RhoGEF domain). The in vivo studies of neural signaling in C. elegans suggest a model in which the heterotrimeric $G$ proteins present in a neuron act to integrate signaling through the multiple GPCRs present on the neuron to produce its appropriate output level. 


\subsection{Heterotrimeric $\mathrm{G}$ proteins that mediate neurotransmitter signaling}

I will focus here on the $G$ protein subunits that mediate neurotransmitter signaling, and refer readers to an earlier review for a table listing all $\mathrm{G} \alpha, \mathrm{G} \beta$, and $\mathrm{G} \gamma$ subunits in C. elegans, and for discussion of the large family of specialized C. elegans $\mathrm{G} \alpha$ proteins found in sensory neurons that mediate chemosensation (see WormBook chapter Heterotrimeric $\mathrm{G}$ proteins in C. elegans).

In C. elegans, as in mammals, there are multiple $\mathrm{G}$ protein $\alpha, \beta$, and $\gamma$ subunits that can potentially combine to form a larger number of heterotrimeric combinations. In mammals there are few functional differences between the various $\beta$ and $\gamma$ subunits (Khan et al., 2013). In C. elegans only one $\beta$ subunit homolog is actually used in G protein heterotrimers (Zwaal et al., 1996; Chase et al., 2001; Robatzek et al., 2001; van der Linden et al., 2001), and only one $\gamma$ subunit is expressed outside the chemosensory neurons (Jansen et al. 2002). Thus in C. elegans, as in mammals, functional diversity among $\mathrm{G}$ protein heterotrimers rests primarily on which $\alpha$ subunit is used. Mammals have multiple members of each of four families of $\alpha$ subunits, while $C$. elegans has just one member for each of these four $\alpha$ families (Jansen et al., 1999). The four conserved C. elegans $\alpha$ subunits, with their corresponding mammalian orthologs and percent sequence identities to them, are: GOA-1 $\left(\mathrm{G} \alpha_{\mathrm{o}},>80 \%\right)$, EGL-30 $\left(\mathrm{G} \alpha_{\mathrm{q}},>80 \%\right)$, GSA-1 $\left(\mathrm{G} \alpha_{\mathrm{s}}, 66 \%\right)$, and GPA-12 $\left(\mathrm{G} \alpha_{12}, 52 \%\right)$. These worm $\mathrm{G} \alpha$ proteins are each more similar to their mammalian orthologs than they are to each other. Below I will use the mammalian names to refer to the worm G $\alpha$ proteins, for example using $\mathrm{G} \alpha_{o}$ to refer to its $C$. elegans ortholog GOA-1. The worm $G \alpha_{o}, G \alpha_{\mathfrak{q}}$, and $G \alpha_{s}$ proteins are each widely expressed in most or all neurons, plus some muscle and other cells (Mendel et al., 1995; Ségalat et al., 1995;

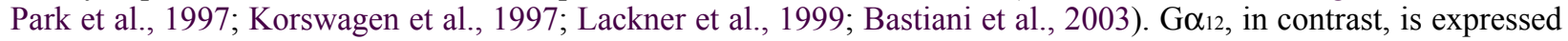
in only a small subset of neurons plus some muscle and hypodermal cells (van der Linden et al., 2003; Yau et al., 2003).

I note as an aside that while GOA-1 appears to be the $\mathrm{G} \alpha_{0}$ ortholog in C. elegans, there are also two more distantly related $\mathrm{G} \alpha_{0}$ homologs that have some functional redundancy with GOA-1. GPA-16 is co-expressed with GOA-1 in some neurons (Jansen et al., 1999) and in early embryonic cells, where these two G $\alpha$ proteins function redundantly to control mitotic spindle positioning during asymmetric cell divisions (reviewed in Polarity establishment, asymmetric division and segregation of fate determinants in early C. elegans embryos). GPA-7 is another $\mathrm{G \alpha}_{\mathrm{o}}$-related protein that shows expression in many neurons (Jansen et al., 1999). The functions of GPA-7 have not been carefully investigated, but in one study GPA-7 and GOA-1 were shown to function redundantly to mediate dopamine signaling in C. elegans male copulatory neurons and muscles (Correa et al., 2012;).

Studies of mammalian GPCRs demonstrate that any one receptor may activate $G \alpha_{0}, G \alpha_{q}, G \alpha_{s}$, or $G \alpha_{12}$, but

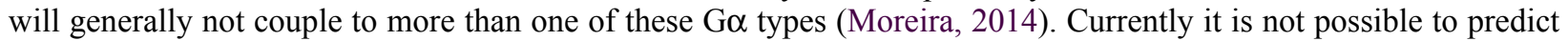
from the sequence of a GPCR which G $\alpha$ protein it will activate, so this must be determined experimentally (see Section 2.1.2).

C. elegans $\mathrm{G} \alpha_{12}$, like mammalian $\mathrm{G}_{12}$, can activate its effector protein RGS-RhoGEF protein (RHGF-1 in $C$. elegans) to in turn activate the small GTPase Rho, and genetic work in C. elegans shows this can regulate a pathway involving diacylglycerol and protein kinase $\mathrm{C}$ to increase neurotransmitter release (van der Linden et al., 2003; Yau et al., 2003; Hiley et al., 2006). However, these results all arise from studies of worms expressing constitutively active mutants of $G \alpha_{12}$, and no defects have yet been observed in worms carrying loss of function mutations in $G \alpha_{12}$ or its effector RHGF-1. Thus the normal physiological functions of the $\mathrm{G} \alpha_{12}$ pathway in C. elegans remain to be elucidated. I will not further consider G $\alpha_{12}$ signaling here, but see Perez-Mansilla and Nurrish (2009)) for a detailed review of C. elegans $\mathrm{G} \alpha_{12}$ signaling.

\subsection{Introduction to the genetics of $\mathrm{G} \alpha_{o}, \mathrm{G} \alpha_{\mathfrak{q}}$, and $\mathrm{G} \alpha_{\mathrm{s}}$}

Before delving into the details of the signaling pathways for the three major neural $G$ proteins, I begin with an overview of what these pathways do and a description of the genetic approaches in C. elegans that have been used to study them.

\subsubsection{A simplified overview: $\mathrm{G} \alpha_{o}, \mathrm{G} \alpha_{q}$, and $\mathrm{G} \alpha_{s}$ signaling regulate neurotransmitter release}

The simplified take-home message from genetic analysis of $\mathrm{G} \alpha_{\mathrm{o}}, \mathrm{G} \alpha_{\mathrm{q}}$, and $\mathrm{G} \alpha_{\mathrm{s}}$ signaling in C. elegans neurons is that $G \alpha_{0}$ signaling inhibits neurotransmitter release, while $G \alpha_{q}$ and $G \alpha_{s}$ signaling activate neurotransmitter release or promote synaptic activity (Figure 2). $G \alpha_{0}$ and $G \alpha_{q}$ signaling appear to affect the 
localization of specific molecules at presynaptic release sites that regulate the neurotransmitter release machinery itself (Lackner et al., 1999; Nurrish et al., 1999; Chan et al., 2012), while it remains less clear how Go s signaling promotes neurotransmitter release (Reynolds et al., 2005). A single neuron expresses many GPCRs (see Section 2), so at any one time all three pathways may be active simultaneously, and indeed there may be receptors for different neurotransmitters activating a single type of $\mathrm{G} \alpha$ protein simultaneously. Thus $\mathrm{G} \alpha_{\mathrm{o}}, \mathrm{G} \alpha_{\mathrm{q}}$, and $\mathrm{G} \alpha_{\mathrm{s}}$ sum up signaling by the several GPCRs active on a neuron, and their three downstream signaling pathways function together to compute an appropriate efficiency for the neurotransmitter release machinery in the neuron.

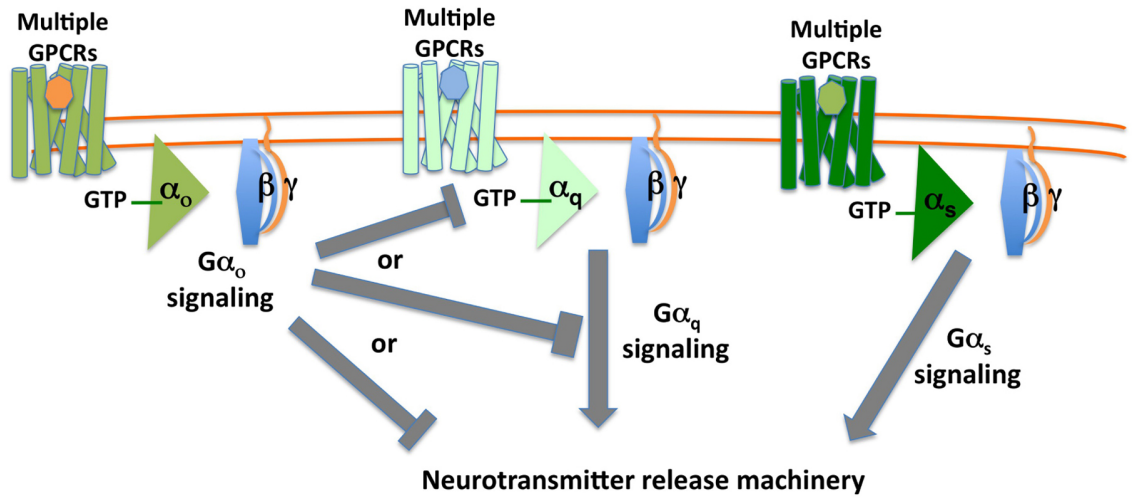

Figure 2. Schematic diagram illustrating how $G \alpha_{0}, G \alpha_{q}$, and $\mathbf{G} \alpha_{s}$ signaling act in a single neuron to together regulate neurotransmitter release. A schematic summary of the effects of signaling by the three $\mathrm{G} \alpha$ proteins on neurotransmitter release, as predicted from genetic studies in $C$. elegans. In such diagrams, an arrow indicates promotion or activation of a target, while a bar denotes an inhibitory effect. The bars extending from Go indicate that genetic experiments show $G \alpha_{o}$ signaling inhibits $G \alpha_{q}$ signaling, but do not determine whether this inhibition occurs upstream of $G \alpha_{q}$, at the level of $G \alpha_{q}$, or at some level downstream of $\mathrm{G} \alpha_{0}$.

Figure 2 is a gross simplification. The neurotransmitter release machinery is complex, with distinct pools of small-clear vesicles present at presynaptic termini, as well as dense-core vesicles at non-synaptic sites, and release can occur tonically or after being evoked by depolarization. Go signaling may differentially affect the various types of vesicle release (Hu et al., 2015). Further, $\mathrm{G} \alpha_{\mathrm{o}}, \mathrm{G} \alpha_{\mathrm{q}}$, and $\mathrm{G} \alpha_{\mathrm{s}}$ signaling are known from electrophysiological studies to affect activity of specific ion channels, and from studies in other experimental systems to affect gene expression and synaptic structure. These $G$ proteins are expressed not only in neurons but also in other cell types (e.g., muscles). So, clearly signaling by $G \alpha_{o}, G \alpha_{q}$, and $G \alpha_{s}$ must have effects other than on the neurotransmitter release machinery. Despite this, studies in $C$. elegans have focused on the effects of G protein signaling on synaptic neurotransmitter release because genetic experiments demonstrate that they actually affect behavior.

There are multiple lines of evidence that $\mathrm{G} \alpha_{\mathrm{o}}, \mathrm{G} \alpha_{\mathrm{q}}$, and $\mathrm{G} \alpha_{\mathrm{s}}$ signaling affect neurotransmitter release in $C$. elegans, with the most extensive evidence coming from studies of acetylcholine release by ventral chord motor neurons that control locomotion behavior. The four major lines of evidence are: 1) mutations in the G proteins and/or their signaling pathways alter locomotion behavior; 2) mutations in the G proteins and/or their signaling pathways alter response to aldicarb, an inhibitor of the acetylcholinesterase enzyme that clears released acetylcholine from synapses; 3 ) mutations in the $G$ proteins and/or their signaling pathways alter the localization of GFP-tagged presynaptic proteins at cholinergic synapses; and 4) mutations in the G proteins and/or their signaling pathways cause changes in acetylcholine release that can be measured with electrophysiological methods. The specific studies detailing these lines of evidence for $G \alpha_{o}, G \alpha_{q}$, and $G \alpha_{s}$ are described and cited below in the remainder of Section 3. As these details will show, all four lines of experimental evidence have established the effects of $G \alpha_{o}$ and $G \alpha_{q}$ signaling on acetylcholine release in C. elegans, while the effects of $G \alpha_{s}$ signaling on acetylcholine release from $C$. elegans ventral cord motor neurons rest on just the first two lines of evidence. However additional lines of evidence for the effects of $\mathrm{G} \alpha_{s}$ signaling on neurotransmitter release come from studies of other cell types and species. For example studies in C. elegans ALA neurons show that the $\mathrm{G} \alpha_{\mathrm{s}}$ signaling pathway affects dense-core vesicle release (Zhou et al., 2007), and electrophysiological studies in mammalian and Drosophila neurons have also established effects of $\mathrm{G}_{\mathrm{s}}$ signaling on release of small clear neurotransmitter vesicles (Trudeau et al., 1996; Chen and Regehr, 1997; Kuromi and Kidokoro, 2000).

\subsubsection{Isolation of $\mathrm{G} \alpha_{o}, \mathrm{G} \alpha_{q}$, and $\mathrm{G} \alpha_{s}$ signaling mutants}

Studies of $C$. elegans neural G protein signaling have been carried out in parallel through both forward and reverse genetics. In the reverse genetic approach, $C$. elegans homologs of mammalian signaling proteins are knocked out by gene-targeting technologies. Thus, for example, the entire sets of G protein subunit genes and RGS 
genes have been knocked out and analyzed (Jansen et al., 1999; Hess et al., 2004). The special power of the $C$. elegans system, however, is its capacity for large-scale forward genetic screens in which the genome is randomly mutagenized and vast numbers of animals are screened for specific phenotypes associated with neural G protein signaling defects. The initial screens for mutants with general neural $\mathrm{G}$ protein signaling defects took advantage of the fact that heterotrimeric $G$ proteins regulate neurotransmitter release from the egg-laying motor neurons and from the cholinergic motor neurons that control locomotion. Thus these screens looked for mutants that fail to lay eggs (Trent et al., 1983; Desai and Horvitz, 1989), that lay eggs too frequently (Bany et al., 2003), that alter acetylcholine release (Miller et al., 1996; Miller et al., 1999; Miller et al., 2000; Sieburth et al., 2005; Vashlishan et al., 2008), that carry suppressors of previously-isolated G protein signaling mutations (Miller et al., 1999; Schade et al., 2005; Charlie et al., 2006b; Williams et al., 2007), or that have hyperactive locomotion (Schade et al., 2005). Additional screens were for mutants that fail to respond to specific neurotransmitters that signal through GPCRs, including dopamine (Chase et al., 2004: ) and serotonin (Gürel et al., 2012).

\subsubsection{Phenotypes of $\mathrm{G} \alpha_{\mathrm{o}}, \mathrm{G} \alpha_{\mathrm{q}}$, and $\mathrm{G} \alpha_{\mathrm{s}}$ signaling mutants}

All genetic studies of neural $\mathrm{G}$ protein signaling in C. elegans involve assaying mutant phenotypes that arise from $\mathrm{G}$ protein signaling defects. Here I describe some of the mutant phenotypes used for this work.

G⿰冫欠 $\alpha_{\circ}$ null and partial loss-of-function mutants have a "hyperactive" phenotype (Mendel et al., 1995; Ségalat et al., 1995), which, as described below, appears to arise from increased neurotransmitter release from neurons throughout the animal. This phenotype can easily be recognized by observing animals growing on a standard laboratory petri dish (Movie 1) and includes body bends that are deeper and more frequent than in the wild type. This defect arises at least in part from increased release of acetylcholine from the ventral cord motor neurons that control locomotion (Vashlishan et al., 2008). The hyperactive phenotype also includes an increased frequency of egg-laying behavior, such that animals lay almost all their eggs as soon as they are produced, so that whereas a wild-type animal might carry 12 unlaid eggs on average, a hyperactive mutant might carry only one or two (Movie 1). This defect arises at least in part from increased neurotransmitter release from the HSN motor neurons that stimulate egg laying (Tanis et al., 2008). Specific serotonin and dopamine receptors signal through $G \alpha_{o}$ to inhibit locomotion, such that treating worms with sufficiently high concentrations of dopamine or serotonin paralyzes wild-type worms, but hyperactive $\mathrm{G} \alpha_{o}$ mutants are resistant to paralysis by serotonin or dopamine (Ségalat et al., 1995; Chase et al., 2004; Gürel et al., 2012). As might be expected, since $G \alpha_{o}$ is expressed in many neurons and non-neuronal cells, $\mathrm{G} \alpha_{0}$ mutants have a number of additional phenotypic defects, including defects in mitotic spindle movements in early embryonic cells (Miller and Rand, 2000; Gotta and Ahringer, 2001) and defects in meiotic maturation of germ cells (Govindan et al., 2006).

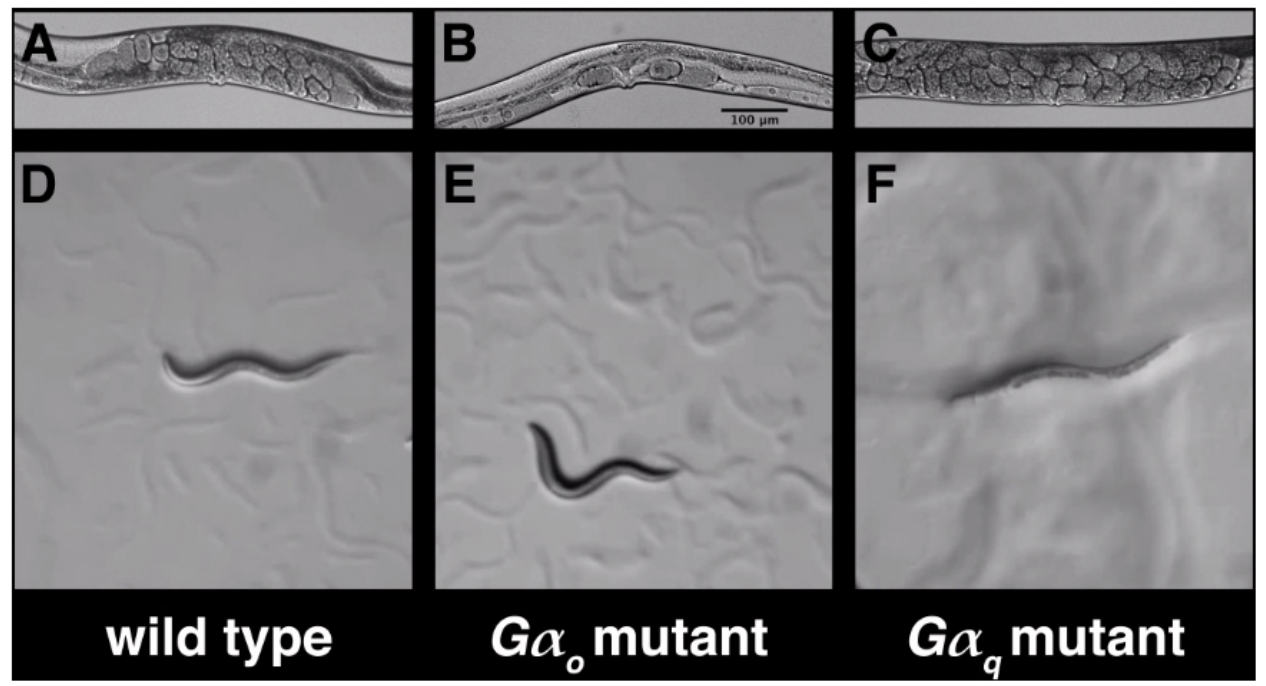

Movie 1. The opposite effects of $\mathbf{G} \alpha_{0}$ and $\mathbf{G} \alpha_{q}$ loss-of-function mutations on behavior. A-C, still images of adult mid-body regions of wild type, goa-1(n1134) Go partial loss-of-function mutant, and egl-30(n686) $\mathrm{G} \alpha_{\mathrm{q}}$ partial loss-of-function mutant animals, respectively. Unlaid eggs are visible as

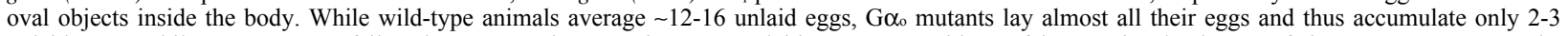
unlaid eggs, while $\mathrm{G} \alpha_{\mathrm{q}}$ mutants fail to lay eggs and accumulate $<40$ unlaid eggs. D-F, videos of locomotion by larvae of the same genotypes. The locomotion defects seen are most obvious in larvae but adults show qualitatively similar defects. G $\alpha_{0}$ mutants show hyperactive locomotion, with more frequent and deeper body bends, and more frequent reversals. G $\alpha_{q}$ mutants show sluggish locomotion, with infrequent, shallow body bends. Magnification is the same in all images, so the scale bar in B applies to all panels. 
$\mathrm{G} \alpha_{\mathrm{q}}$ null mutants undergo developmental arrest as young larvae (Reynolds et al., 2005), but partial loss-of-function mutants develop to adulthood and show a "sluggish" phenotype that appears to arise from decreased neurotransmitter release (Lackner et al., 1999; Miller et al., 1999) from neurons throughout the animal (Bastiani et al., 2003). Sluggish animals have less frequent and shallower body bends than in the wild type, and strong loss-of-function or null $\mathrm{G} \alpha_{\mathrm{q}}$ mutants are virtually paralyzed (Movie 1) (Reynolds et al., 2005; Williams et al., 2007). This defect results at least in part from decreased acetylcholine release from ventral cord motor neurons (Lackner et al., 1999; Hu et al., 2015). Sluggish animals rarely engage in egg-laying behavior, such that adult animals can become bloated with up to $~ 50$ unlaid eggs (Movie 1), and this defect arises at least in part from decreased neurotransmitter release from the HSN motor neurons (Tanis et al., 2008).

The $G \alpha_{o}$ and $G \alpha_{q}$ loss-of-function phenotypes are in many respects precisely the opposite of each other. This interpretation is reinforced by the fact that mutations and transgenes that increase $G \alpha_{0}$ signaling cause a sluggish phenotype essentially indistinguishable from that seen in $\mathrm{G \alpha}_{q}$ loss-of-function mutants (Mendel et al., 1995; Ségalat et al., 1995; Koelle and Horvitz, 1996), while transgenes and mutations that increase $\mathrm{G \alpha}_{\mathrm{q}}$ signaling cause a hyperactive phenotype virtually indistinguishable from that seen in $\mathrm{G} \alpha_{\mathrm{o}}$ loss-of-function mutants (Bastiani et al., 2003; Hajdu-Cronin et al., 1999; Schade et al., 2005; Reynolds et al., 2005; Charlie et al., 2006a; Williams et al., 2007; Matsuki et al., 2006).

Gos null mutations are lethal (Korswagen et al., 1997), but mutations that decrease $G \alpha_{\text {s }}$ signaling cause a sluggish, near-paralyzed locomotion phenotype similar to that of $\mathrm{G} \alpha_{q}$ loss-of-function mutants (Moorman and Plasterk, 2002; Reynolds et al., 2005). Mutations and transgenes that increase $G \alpha_{\text {s signaling induce a smoothly }}$

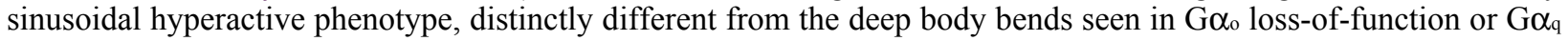
gain-of-function mutants (Reynolds et al., 2005; Schade et al., 2005; Charlie et al., 2006a).

\subsubsection{The neuromuscular junction and the egg-laying synapse are often used to study neural $G$ protein signaling in C. elegans}

While $\mathrm{G} \alpha_{\mathrm{o}}, \mathrm{G} \alpha_{\mathrm{q}}$, and $\mathrm{G} \alpha_{\mathrm{s}}$ signaling affect many C. elegans behaviors, locomotion and egg-laying behaviors are two readouts of neural $G$ protein signaling that have been frequently used to carry out genetic studies of the mechanism of neural $\mathrm{G}$ protein signaling due to the unique advantages of each.

Egg-laying behavior depends on release of serotonin and other neurotransmitters from the HSN motor neuron. $G \alpha_{o}$ and $G \alpha_{q}$ have opposing effects on HSN neurotransmitter release (Tanis et al., 2008), and mutations in their signaling pathways result in easily scored and quantitated defects in egg laying (Chase and Koelle, 2004). Thus it has been possible to carry out genetic screens for mutants that are defective or hyperactive for egg-laying behavior to isolate mutants with defects in $\mathrm{G \alpha}_{o}$ and $\mathrm{G} \alpha_{q}$ signaling (Trent et al., 1983; Desai and Horvitz, 1989; Bany et al., 2003). Such mutants were used to originally discover and subsequently characterize the Regulators of G protein Signaling (RGS proteins) that inhibit most neural G protein signaling in C. elegans and in mammals (Koelle and Horvitz, 1996; Hajdu-Cronin et al., 1999). The neural circuit that controls egg laying is particularly simple and well-characterized, and tools to express transgenes in any cell of the circuit, to monitor activity of the circuit in freely-behaving animals with the fluorescent $\mathrm{Ca}^{2+}$ indicator GCaMP, and to optogenetically manipulate the circuit have all been developed (Schafer, 2006; Emtage et al., 2012; Collins and Koelle, 2013).

C. elegans locomotion behavior involves release of acetylcholine from ventral cord motor neurons onto body wall muscles, and $\mathrm{G} \alpha_{o}, G \alpha_{q}$, and $\mathrm{G} \alpha_{\mathrm{s}}$ all affect acetylcholine release at this neuromuscular junction. The drug aldicarb paralyzes worms by preventing acetylcholine released at this neuromuscular junction from being degraded, and a powerful genetic screen for mutants resistant to aldicarb paralysis has been used to isolate mutants with decreased acetylcholine release that lie in the $\mathrm{G} \alpha_{o}$ and $\mathrm{G} \alpha_{\mathrm{q}}$ signaling pathways (Miller et al., 1996; Miller et al., 1999; Miller et al., 2000). Screens for suppressors of aldicarb-resistant mutants and screens for mutants with hyperactive locomotion were used to isolate mutants with increased signaling in the $G \alpha_{\mathrm{s}}$ and $\mathrm{G} \alpha_{\mathrm{q}}$ pathways (Miller et al., 1999; Schade et al., 2005; Charlie et al., 2006b). Mutations that affect acetylcholine release were used to discover the RIC-8 protein that promotes signaling by heterotrimeric G proteins in C. elegans and in mammals (Miller et al., 2000). The cholinergic neuromuscular junctions in the ventral cord have been used for important experiments visualizing the effects of $\mathrm{G}$ protein signaling mutations on the localization of synaptic vesicle release proteins (Lackner et al., 1999; Nurrish et al., 1999; Chan et al., 2012). These neuromuscular junctions are also the most accessible synapses for electrophysiological studies in C. elegans, and have allowed studies of the fine details of $\mathrm{G}$ protein signaling mutations on neurotransmitter release (Hu et al., 2015). 
While mutations in the $G \alpha_{o}, G \alpha_{q}$ and $G \alpha_{s}$ signaling pathways have powerful effects on egg-laying behavior by affecting neurotransmitter release from the HSN neurons and on locomotion by affecting acetylcholine release from ventral cord motor neurons, it has been hard to identify the GPCRs that activate the G proteins in these neurons. This difficulty is in line with the understanding, described in Section 2, that an individual neuron appears to express many different GPCRs so that mutations in a single GPCR are expected to have very weak effects compared to mutations in a G protein. In the HSN neuron, the EGL-6 neuropeptide receptor signals through G $\alpha_{o}$ to inhibit egg laying, but this effect is only obvious in gain-of-function EGL-6 mutants, whereas EGL-6 null mutants do not have detectable defects. In the ventral cord motor neurons, the neuropeptide receptor CKR-2 and the G protein coupled acetylcholine receptor GAR-3 both appear to signal through $\mathrm{G} \alpha_{q}$ to increase acetylcholine release (Hu et al., 2011; Chan J.P. et al., 2013), while a different G protein coupled acetylcholine receptor GAR-2, the heterodimeric G protein coupled GABAв receptor GBB-1/GBB-2, and the dopamine receptor DOP-3 all appear to signal through $\mathrm{G} \alpha_{0}$ to decrease acetylcholine release (Chase et al., 2004; Dittman and Kaplan, 2008). Mutations in these ventral cord motor neuron GPCRs have detectable effects on locomotion (Chase et al., 2004; Dittman and Kaplan, 2008; Hu et al., 2011; Chan J.P. et al., 2013), but knocking out a single one of these GPCRs, as expected, has much weaker effects than does knocking out its downstream G protein (Mendel et al., 1995; Ségalat et al., 1995; Brundage et al., 1996).

\subsection{The mechanism of $\mathrm{G} \alpha_{q}$ signaling}

In mammalian cells, active $G \alpha_{q}-G T P$ is classically known to signal by directly binding to and activating its effector, the transmembrane enzyme phospholipase $C \beta$ (PLC $\beta$ ), which hydrolyzes the membrane lipid phosphatidylinositol 4,5 bisphosphate ( $\left.\mathrm{PIP}_{2}\right)$ to generate the soluble molecule inositol 1,4,5 trisphosphate (IP 3 ) and the membrane lipid diacylglycerol (DAG). IP 3 can go on to increase intracellular $\mathrm{Ca}^{2+}$, which along with DAG can bind and activate protein kinase C (Figure 3; reviewed by Sánchez-Fernández et al., 2014). Prior to studies of $G \alpha_{q}$ signaling in $C$. elegans, the only confirmed direct $G \alpha_{q}$ effector was PLC $\beta$. Genetic analysis of $\alpha_{q}$ signaling in $C$. elegans (previously reviewed by Perez-Mansilla and Nurrish, 2009) supported the idea that PLC $\beta$ (EGL-8 in $C$. elegans) is a physiologically important effector (Lackner et al., 1999, Miller et al., 1999; Bastiani et al., 2003). However, these same studies also suggested that there had to be additional $G \alpha_{q}$ effector(s) since the phenotypes of PLC $\beta$ null mutants were much less severe than those of $G \alpha_{q}$ null mutants.

The missing $G \alpha_{q}$ effector was identified as the Trio RhoGEF through genetic screens for suppressors of the slow growth and hyperactive locomotion phenotypes caused by excessive $\mathrm{G} \alpha_{q}$ pathway activity (Williams et al., 2007). Analysis using loss- and gain-of-function mutants in various double-mutant combinations showed that for control of growth, locomotion, and egg laying, G $\alpha_{q}$ signals through both PLC $\beta$ and Trio RhoGEF. Knocking out either effector alone only partially blocks $G \alpha_{q}$ signaling, while knocking out both appears to completely block $G \alpha_{q}$ signaling (Williams et al., 2007). Trio RhoGEF proved to be as or more important than the classical PLC $\beta$ effector pathway for multiple effects of $\mathrm{G \alpha}_{q}$ signaling, including effects on growth, locomotion, and egg laying. Concomitant with the discovery of Trio RhoGEF as a $\mathrm{G \alpha}_{\mathrm{q}}$ effector in C. elegans, biochemical and structural studies demonstrated that mammalian $\mathrm{G \alpha}_{\mathrm{q}}$ binds and activates the orthologous mammalian RhoGEF proteins (Lutz et al., 2007; Rojas et al., 2007). 


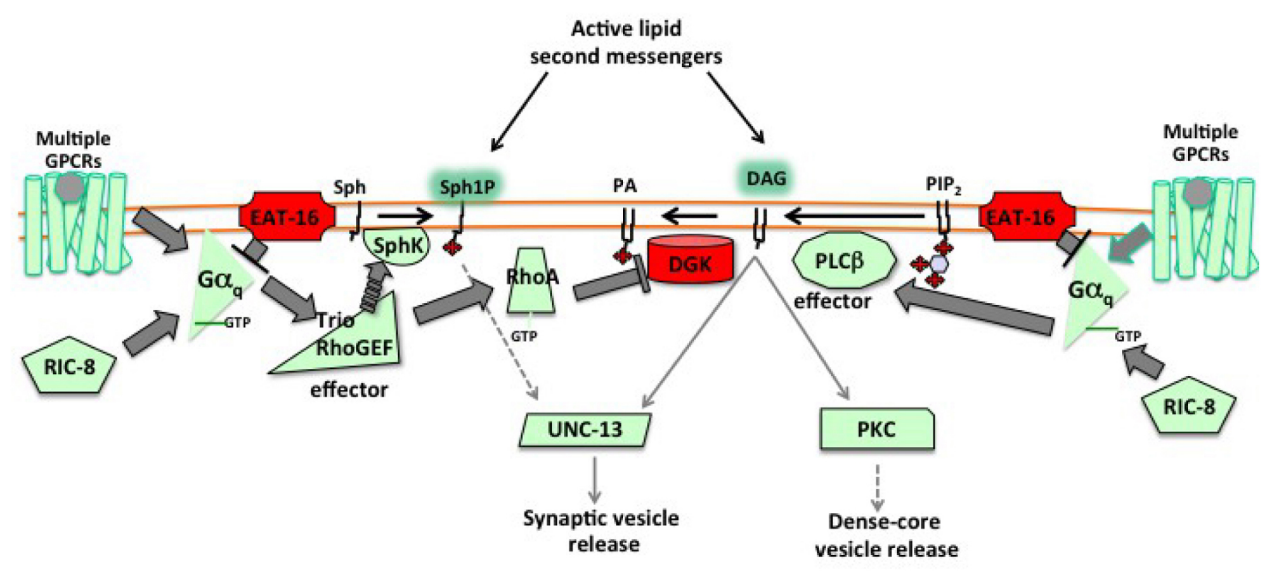

Figure 3. Mechanism of $\mathbf{G} \alpha_{q}$ signaling. G $\alpha_{q}$ is induced to bind GTP to generate its active form by GPCRs, and induced to hydrolyze GTP to generate its inactive form by the RGS protein EAT-16. RIC- 8 promotes $G \alpha_{q}$ signaling by acting as a chaperone to stabilize G $\alpha_{q}$ protein and/or by acting as a

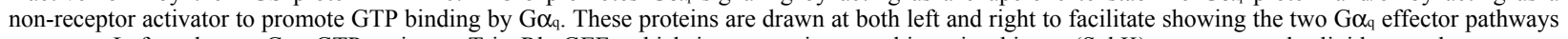
at center. Left pathway: Goq-GTP activates Trio RhoGEF, which in turn activates sphingosine kinase (SphK) to generate the lipid second messenger sphingosine 1-phosphate (Sph1P). Trio RhoGEF also increases levels of another lipid second messenger diacylglycerol (DAG) by activating RhoA to prevent diacylglycerol kinase (DGK) from converting DAG to phosphatidic acid (PA). Right pathway: G $\alpha_{q}-G T P$ activates phospholipase C $\beta$ (PLC $\beta$ ) to generate the second messengers DAG and (not shown) $\mathrm{IP}_{3}$. Sph1P and DAG each help UNC-13 to relocalize to synaptic membranes and to promote synaptic vesicle release. DAG also activates protein kinase C (PKC) to promote dense-core vesicle release. Solid grey arrows (or bars), activation (or inhibition) via direct physical interactions. Dashed arrows or bars, indirect or poorly understood effects. Light green, proteins that promote G⿰ $\alpha_{\mathrm{q}}$ signaling; red, proteins that inhibit $\mathrm{G} \alpha_{\mathrm{q}}$ signaling.

Two mechanisms for signaling downstream of the Trio RhoGEF effector of $G \alpha_{q}$ have been identified based on C. elegans genetics (Figure 3). First, while PLC $\beta$ enzyme activity directly produces DAG, Trio RhoGEF can also increase DAG levels by an indirect mechanism. Trio RhoGEF activates the RhoA protein RHO-1, allowing it to directly bind and inhibit the diacylglycerol kinase DGK-1, blocking the first step in metabolic clearance of DAG, its phosphorylation to produce phosphatidic acid (PA) (McMullan et al., 2006). Thus both effectors for G $\alpha_{q}$ collaborate to increase DAG levels. Although Rho activity in mammals is principally known to regulate other processes, such as actin cytoskeleton dynamics and transcription, C. elegans genetics demonstrates that in its role mediating neurotransmitter signaling downstream of $\mathrm{G \alpha}_{\mathrm{q}}$, a major physiologically significant role of Rho seems to be increasing DAG levels.

A second downstream mediator of the effects of $\mathrm{G}_{\alpha} / \mathrm{RhoGEF} / \mathrm{RhoA}$ signaling is the sphingosine kinase SphK (SPHK-1 in C. elegans). SphK catalyzes the phosphorylation of the membrane lipid sphingosine (Sph) to sphingosine-1-phosphate (Sph1P), a signaling lipid that among other functions promotes neurotransmitter release (Okada et al., 2009). In ventral cord cholinergic neurons, $G \alpha_{q}$ signaling via the Trio RhoGEF UNC-73 causes an increase in the perisynaptic localization of SphK, and this in turn appears to increase acetylcholine release (Chan et al., 2012). In a separate study, it was found that $G \alpha_{q}$ signaling recruits $\mathrm{SphK}$ to synapses via calcium influx using a mechanism involving the calcium binding protein CIB (CALM-1 in C. elegans) (Chan et al., 2012). The ability of SphK to increase neurotransmitter release depends on both its localization to perisynaptic regions and its ability to generate sphingosine 1-phosphate (Chan et al., 2012). At this point, the details of the mechanism by which Trio RhoGEF leads to recruitment of SphK to perisynaptic regions, and specifically the relationship between the calcium and Trio RhoGEF effects on Sphk localization, remain to be determined.

How does the second messenger DAG produced by $\mathrm{G} \alpha_{q}$ signaling lead to the ultimate effect of $\mathrm{G}_{\mathrm{q}}$ signaling, an increase in neurotransmitter release? Two DAG- binding proteins appear to mediate independent effects. One of these, UNC-13, is a protein essential for synaptic vesicle priming that facilitates neurotransmitter release by binding to the SNARE protein complexes that mediate vesicle fusion (James and Martin, 2013). Binding of UNC-13 to DAG in the membrane may help recruit it to synaptic membranes. The evidence for G $\alpha_{q}$ acting through UNC-13 includes the observations that in ventral cord motor neurons, $\mathrm{G} \alpha_{q}$ activation of acetylcholine release depends on UNC-13, and that $\mathrm{G} \alpha_{\mathrm{q}}$ activation or addition of DAG analogs induces overexpressed UNC-13S::GFP to relocalize from a diffuse pattern in axons to punctate structures at synapses (Lackner et al., 1999). These effects can be abrogated by a mutation that blocks the ability of overexpressed UNC-13S::GFP to bind DAG. Recent electrophysiological studies provide perhaps the strongest evidence that UNC-13 functions in $\mathrm{G}_{\mathrm{q}}$ signaling to promote acetylcholine release from ventral cord motor neurons, with both the long and short isoforms of UNC-13 differentially affecting tonic and evoked release (Hu et al., 2015). Nevertheless, the extent to which UNC-13 mediates the behavioral effects of $\mathrm{G} \alpha_{q}$ signaling has remained unclear. The recent development of methods for 
precise genome engineering using CRISPR/Cas9 provide an opportunity to mutate the DAG binding site of native $\mathrm{UNC}-13$ and potentially resolve this issue.

A second DAG binding protein that mediates effects of $G \alpha_{q}$ signaling in ventral cord motor neurons is protein kinase C (PKC) (Sieburth et al., 2007). PKC appears to affect release of neuropeptide-containing dense-core vesicles, although the targets via which PKC does this remain unknown. PKC does not appear to directly affect release of acetylcholine from small-clear synaptic vesicles. UNC-13 appears to affect small-clear vesicles, and there are differences of opinion as to whether it directly affects dense-core vesicles release (Sieburth et al., 2007; Speese et al., 2007). Thus the current model is that $G \alpha_{q}$ signaling produces DAG to act via two different DAG-binding proteins, PKC and UNC-13, that together activate release of dense-core and synaptic vesicles (Figure 3).

A key observation about the role of DAG in $G \alpha_{q}$ signaling is that treating $G \alpha_{q}$ mutant worms with the DAG analogs known as phorbol esters rescues the paralysis of $\mathrm{G} \alpha_{q}$ null and strong reduction-of-function mutants to wild-type levels of coordinated locomotion (Reynolds et al., 2005; Williams et al., 2007). The effectiveness of such non-localized phorbol ester treatment suggests that DAG is a "licensing factor" that promotes neurotransmitter release, i.e., that DAG need not be produced focally at synapses. Further, the fact that $G \alpha_{q}$ mutants can be rescued by phorbol ester treatment demonstrates that developmental defects do not contribute to the strong paralysis of $G \alpha_{q}$ strong loss-of-function or null mutants.

How does the other second messenger produced by $G \alpha_{q}$ signaling, sphingosine 1-phosphate, increase neurotransmitter release? An initial study suggested the effect of $\mathrm{G} \alpha_{q}$ on neurotransmitter release via SphK appeared to be entirely independent and parallel to the ability of $\mathrm{G} \alpha_{q}$ signaling to increase neurotransmitter release via increasing DAG levels (Chan et al., 2012). However, a subsequent study suggested $\mathrm{SphK}$ is essential for $\mathrm{G} \alpha_{q}$ signaling to relocalize UNC-13S::GFP to synapses (Chan and Sieburth, 2012), and UNC-13S::GFP relocalization also appears to depend on DAG (Lackner et al., 1999). So, more work remains to clarify the relationship of DAG and SphK signaling downstream of $\mathrm{G} \alpha$ in regulating neurotransmitter release.

Two upstream regulators of $\mathrm{G} \alpha_{q}$ were identified through C. elegans genetic analysis. The Regulator of $\mathrm{G}$ protein signaling (RGS) protein EAT-16 behaves as a specific inhibitor of $\mathrm{G} \alpha_{q}$ signaling (Hajdu-Cronin et al., 1999). The RIC-8 protein promotes $\mathrm{G \alpha}_{q}$ signaling (Miller et al., 2000). I will elaborate on studies of RGS proteins and RIC-8 in Section 3.6 and Section 3.7.

\subsection{The mechanism of $\mathrm{G} \alpha$ s signaling}

The Gos signaling pathway (Figure 4) has been intensively studied for decades in mammalian cells using biochemical approaches (Godinho et al., 2015). Go s activated by GPCRs binds and activates its effector, the transmembrane enzyme adenylyl cyclase, which generates the second messenger cyclic AMP (cAMP). cAMP binds the regulatory subunits of protein kinase A (PKA), causing them to dissociate from and thus activate the catalytic subunit, which can then phosphorylate various target proteins. Signaling is terminated in part through the action of the enzyme phosphodiesterase to hydrolyze cAMP. G $\alpha_{\mathrm{s}}$ is unique among $\mathrm{G} \alpha$ isoforms in that no RGS protein is known to act on $G \alpha_{s}$ to help it hydrolyze GTP, so the slow intrinsic GTPase activity of Gos is apparently used to terminate $\mathrm{G} \alpha_{\mathrm{s}}$ activity. 


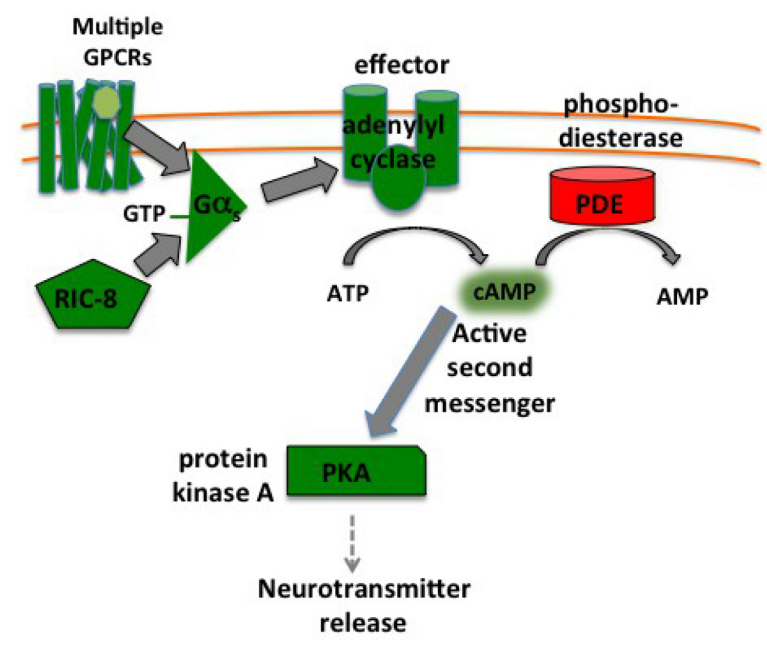

Figure 4. Mechanism of $\mathbf{G} \alpha_{\mathrm{s}}$ signaling. G $\alpha_{\mathrm{s}}$ is induced to bind GTP to generate its active form by GPCRs. RIC-8 promotes signaling, either via its G $\alpha$ chaperone function or as a non-receptor activator. G $\alpha_{s}-G T P$ inactivates itself (not shown) via its slow intrinsic GTPase activity. G $\alpha_{s}-G T P$ activates the transmembrane enzyme adenylyl cyclase to generate the second messenger cyclic AMP (cAMP), which ultimately is hydrolyzed by phosphodiesterase. cAMP binds the regulatory subunits of protein kinase A (PKA), causing them to release the active subunit. PKA phosphorylation of unknown target proteins activates release of both synaptic and dense-core vesicles to increase neurotransmitter release. Solid grey arrows indicate direct physical interactions. Dashed arrow indicates a poorly understood effect. Green, proteins that promote Gos signaling; red, proteins that inhibit Gos signaling.

Genetic studies show that the same pathway delineated by biochemical studies in mammals also operates in $C$. elegans motor neurons (Figure 4; Schade et al., 2005). Initial studies showed that transgenic overexpression of constitutively-active $\mathrm{G} \alpha_{\mathrm{s}}$ kills neurons through a cAMP-dependent mechanism, as the killing could be suppressed with mutations in the adenylyl cyclase ACY-1 (Korswagen et al., 1997; Berger et al., 1998; Moorman and Plasterk, 2002). Go $\alpha_{s}$ null mutants are lethal (Korswagen et al., 1997), but mutants with increased Gos signaling are viable, and have provided important tools for genetic analysis of $\mathrm{G} \alpha_{\mathrm{s}}$ signaling. Mutations that increase $\mathrm{G} \alpha_{\mathrm{s}}$ signaling have been identified in Go $\alpha_{\text {s }}$ itself (GSA-1 in C. elegans), adenylyl cyclase (ACY-1), protein kinase A (loss of the regulatory subunit KIN-2 causes constitutive activity of the catalytic subunit KIN-1), and in phosphodiesterase (PDE-4) (Schade et al., 2005; Charlie et al., 2006b). Increased Gos signaling results in smoothly hyperactive sinusoidal locomotion, which is distinct from the hyperactive locomotion with abnormally deep body bends induced by loss of $\mathrm{G} \alpha_{o}$ signaling or increased $\mathrm{G} \alpha_{q}$ signaling (Schade et al., 2005). Epistasis analysis using $\mathrm{G} \alpha_{\mathrm{s}}$ signaling pathway mutants supports the idea that $G \alpha_{s}$ in C. elegans functions in a pathway analogous to the mammalian $G \alpha_{s}$ signaling pathway that had been characterized biochemically (Schade et al., 2005; Reynolds et al., 2005).

Gos pathway activity requires the guanine nucleotide exchange factor RIC-8, (Reynolds et al., 2005), although it remains unclear if this is due to the function of RIC-8 as chaperone or due to RIC-8 acting as a non-receptor nucleotide exchange protein.

The ultimate effect of $\mathrm{G} \alpha_{\mathrm{s}}$ signaling in neurons appears to be to promote neurotransmitter release. Schade et al. (2015) showed that activating $\mathrm{G \alpha}_{\mathrm{s}}$ signaling in both neurons and muscles using gain-of-function mutations appears to induce acetylcholine release from motor neurons, although Reynolds et al. (2005) showed that loss of acy-1 just in neurons did not seem to affect neurotransmitter release. Separate studies in ALA neurons show that PKA activation can induce dense-core vesicle release (Zhou et al., 2007), so $\mathrm{G} \alpha_{\mathrm{s}}$ signaling may be able to activate neurotransmitter release via both synaptic and dense-core vesicles. The downstream targets of phosphorylation by PKA that increase vesicle release remain unknown.

$\mathrm{G} \alpha_{\mathrm{s}}$ signaling may operate in muscles, in addition to neurons, to control C. elegans behavior. Null mutants for the adenylyl cyclase ACY-1 show two separable defects: larval arrest and near-paralysis. In an acy- 1 null mutant, re-expression of $a c y-1$ in either muscles or neurons can rescue the larval arrest, but neither is sufficient to rescue paralysis, indicating that $a c y-1$ may be required in both neurons and muscles for proper locomotion (Reynolds et al., 2005). Rescue experiments also indicate that $\mathrm{G} \alpha_{\mathrm{s}}$ signaling is required for adult neural function, but is not required for neural development, since induced expression of $a c y-1$ in paralyzed animals lacking neural $a c y-1$ can restore locomotion behavior in these animals (Reynolds et al., 2005).

Genetic studies initiated to study $\mathrm{G} \alpha$ s signaling have led to a broader genetic analysis of the in vivo functions of cAMP in C. elegans. While the adenylyl cyclase ACY-1 mediates all known effects of G $\alpha_{s}$ signaling (Schade et al., 2005), there are other adenylyl cyclase isoforms in C. elegans that appear to generate a $\mathrm{G \alpha}_{\text {s-independent pool of }}$ 
cAMP that also affect locomotion and larval growth (Charlie et al., 2006b). cAMP is an important negative regulator of sleep-like states throughout the animal kingdom (Zimmerman et al., 2008), and $\mathrm{G} \alpha_{\text {s }}$ pathway activating mutants are being used to study sleep-like states in C. elegans (Belfer et al., 2013). Ghosh-Roy et al., (2010) has also used $\mathrm{G} \alpha_{\mathrm{s}}$ pathway mutants to study the role of cAMP in axon regeneration.

\subsection{The mechanism of $\mathrm{G} \alpha_{0}$ signaling}

The mechanism of $G \alpha_{0}$ signaling (Figure 5) is poorly understood and remains an area ripe for further investigation using the $C$. elegans system. Biochemical studies in mammals have shown that $G \alpha_{o}$ is expressed throughout the nervous system and is by orders of magnitude the most abundant $\mathrm{G} \alpha$ protein in neurons, constituting $\sim 1.5 \%$ of membrane protein in the brain (Sternweis and Robishaw, 1984). Despite efforts to identify Goo binding proteins that might function as effectors for $\mathrm{G} \alpha_{o}$ or its paralogs (Chen et al., 1999; Takesono et al., 1999; Cuppen et al., 2003), no such protein has been validated as a bona fide effector of $G \alpha_{o}$. Activation of $G \alpha_{o}$ releases $G \beta \gamma$ subunits, allowing them to activate specific $\mathrm{K}^{+}$channels and inhibit specific $\mathrm{Ca}^{2+}$ channels, resulting in inhibition of neural activity (Reuveny et al., 1994; Herlitze et al., 1996).

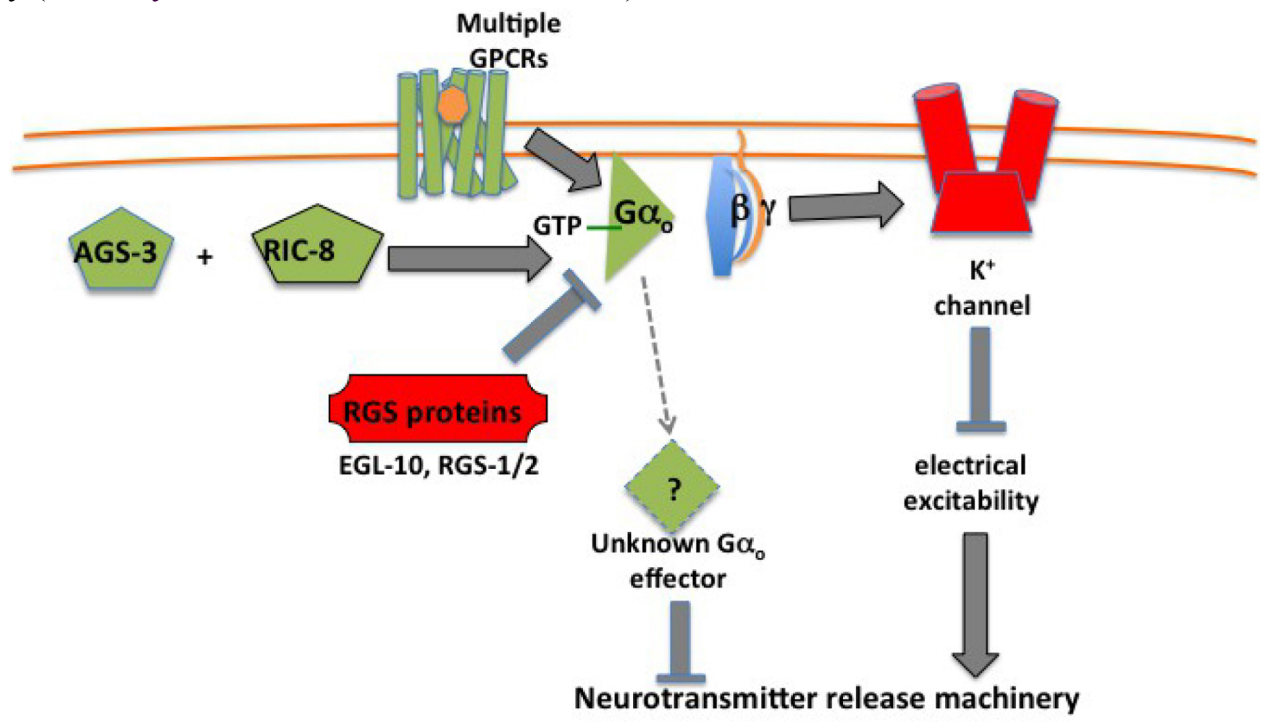

Figure 5. Mechanism of G $\alpha_{0}$ signaling. G $\alpha_{0}$ is induced to bind GTP to generate its active form by GPCRs, or by the non-receptor activators AGS-3 and RIC-8. Alternatively, or in addition, RIC- 8 may function as a chaperone for G $\alpha_{0}$. G $\alpha_{0}$-GTP may signal to inhibit the neurotransmitter release machinery by an unknown effector protein. The $\mathrm{G} \beta \gamma$ subunits released from $\mathrm{G} \alpha_{0}$ can activated specific $\mathrm{K}^{+}$channels to reduce electrical excitability, which in turn facilitates neurotransmitter release. Green, proteins that promote $\mathrm{G} \alpha_{0}$ signaling; red, proteins that inhibit $G \alpha_{o}$ signaling.

The ultimate effect of $\mathrm{G} \alpha_{\mathrm{o}}$ signaling in C. elegans neurons is to inhibit neurotransmitter release, and this has been studied in detail in ventral cord motor neurons, where $\mathrm{G} \alpha_{0}$ signaling inhibits acetylcholine release (Nurrish et

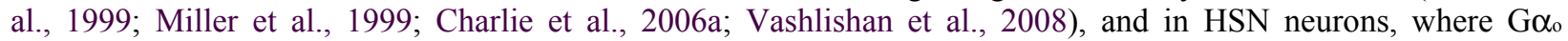
signaling inhibits release of serotonin and other neurotransmitters that stimulate egg laying (Tanis et al., 2008). G $\alpha_{q}$ and $\mathrm{G} \alpha_{o}$ signaling have the opposite effects on locomotion, egg laying, and a variety of other behaviors (Movie 1), suggesting that in general, while $G \alpha_{q}$ signaling promotes neurotransmitter release (see Section 3.2), G $\alpha_{0}$ has an opposing effect of inhibiting neurotransmitter release.

Activation of $\mathrm{G} \alpha_{\mathrm{q}}$ signaling in ventral cord motor neurons appears to increase the localization of the synaptic vesicle priming protein UNC-13S to presynaptic termini, as seen by visualizing a fusion of UNC-13S to the green

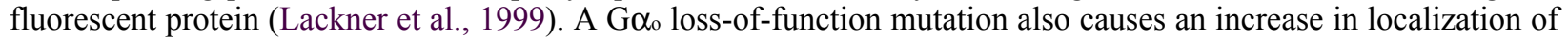
this UNC-13S::GFP protein to presynaptic termini (Nurrish et al., 1999). This result suggests that that $G \alpha_{q}$ and $G \alpha_{o}$ oppose each other at a mechanistic level. The effects of $G \alpha_{q}$ and $G \alpha_{o}$ on UNC-13S::GFP localization both depend on the diacylglycerol (DAG) binding site of UNC-13 (Lackner et al., 1999; Nurrish et al., 1999). Thus it is assumed that the increase in DAG levels produced by $\mathrm{G}_{\mathrm{q}}$ signaling cause the observed changes in UNC-13S::GFP localization. $\mathrm{G} \alpha_{0}$ signaling could affect UNC-13::GFP and inhibit neurotransmitter release by decreasing DAG

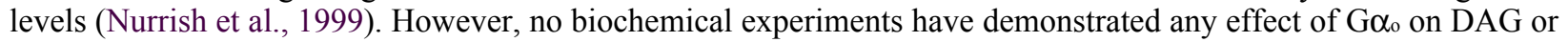
on the enzymes that generate or degrade DAG (Jose and Koelle, 2005; Perez-Mansilla and Nurrish, 2009).

While genetic studies in C. elegans have not clarified the downstream mechanism of $G \alpha_{o}$ signaling, they have identified novel upstream regulators of $\mathrm{G} \alpha_{0}$. The RGS protein EGL-10 is expressed in all neurons, and EGL-10 null 
mutants show sluggish locomotion and egg-laying defects due to increased $\mathrm{G} \alpha_{\circ}$ signaling (Koelle and Horvitz, 1996). There are other RGS proteins (RGS-1, RGS-2, RGS-7) that additionally inhibit Go $\alpha_{o}$ in specific cell types or under specific circumstances (see Section 3.7). Go $\alpha_{o}$ signaling is promoted by RIC-8, working in combination with a GPR-domain containing protein (Section 3.6). As in the case of RIC-8's effect on G $\alpha_{\mathrm{s}}$ signaling (Section 3.3), it is unclear whether RIC-8's effect on G $\alpha_{0}$ signaling reflects its nucleotide exchange activity, its G $\alpha$ chaperone function (Gabay et al., 2011; Chan P. et al., 2013), or both.

\subsubsection{Does $\mathrm{G} \alpha_{\mathrm{o}}$ have an effector?}

One view is that $G \alpha_{0}$ has no effector, and that $G \alpha_{0}$ signaling occurs simply by release of $G \beta \gamma$ subunits that would then be entirely responsible for further downstream signaling by regulating $\mathrm{K}^{+}$and $\mathrm{Ca}^{2+}$ channels. The plausibility of such a scheme is bolstered by careful genetic studies of heterotrimeric $\mathrm{G}$ protein signaling in yeast, in which mating pheromone signaling through a heterotrimeric $\mathrm{G}$ protein is indeed carried out by activation of a $\mathrm{G} \alpha$ protein whose principal function is simply to release $G \beta \gamma$ so that $G \beta \gamma$ can induce further signaling events (Dohlman and Thorner, 2001).

Genetic studies in $C$. elegans strongly suggest that $G \alpha_{0}$ signaling does not proceed purely through $G \beta \gamma$ effectors, and that $\mathrm{G} \alpha_{0}$ must also signal directly through its own yet-to-be-discovered effectors. The only study of G $\beta \gamma$ effectors in C. elegans showed that when the EGL-6 neuropeptide receptor activates G $\alpha_{\circ}$ in the HSN neurons, the resulting inhibition of egg laying requires IRK-1, a homolog of mammalian $\mathrm{G} \beta \gamma$-activated $\mathrm{K}^{+}$channels, and that no other such $\mathrm{K}^{+}$channel is required (Emtage et al., 2012). However, this same study also demonstrated that IRK-1 does not mediate inhibition of egg laying when other methods are used to activate $G \alpha_{o}$, suggesting that other effectors besides $\mathrm{K}^{+}$channels must mediate $\mathrm{G} \alpha_{o}$ signaling. This study leaves open the possibility that these other effectors could be additional $\mathrm{G} \beta \gamma$ effectors such as $\mathrm{Ca}^{2+}$ channels. However, other genetic results argue in favor of effectors for $\mathrm{G} \alpha_{\mathrm{o}}$ itself.

First, $G \alpha_{q}$ and $G \alpha_{0}$ release the identical $G \beta \gamma$ subunits, as there is only one $G \beta \gamma$ isoform generally expressed in C. elegans neurons, yet activation of $G \alpha_{q}$ and $G \alpha_{0}$, acting in the same neurons, have exactly opposite effects on neurotransmitter release and behavior (Lackner et al., 1999; Nurrish et al., 1999; Tanis et al., 2008). To argue that $G \alpha_{0}$ signaling principally results from released $G \beta \gamma$ inhibiting neural activity, one needs to explain how $G \alpha_{q}$ signaling does not give the same result. This discrepancy might result from the far greater abundance of $\mathrm{G}_{0}$, or by supposing that $\mathrm{G} \alpha_{o}$ and $\mathrm{G} \alpha_{q}$ reside in different membrane microdomains, but so far there is no actual data to support either idea.

Second, the genetics of $\mathrm{G} \alpha_{\circ}$ signaling in C. elegans does not match the genetics of G $\beta \gamma$-mediated pheromone signaling pathway in yeast. In the yeast pheromone signaling pathway, a null mutant for the Go subunit results in constitutive signaling, as $\mathrm{G} \alpha$ is no longer present to sequester $\mathrm{G} \beta \gamma$ and inhibit its ability to signal (Whiteway et al., 1989). Conversely, transgenic overexpression of yeast $\mathrm{G} \alpha$ inhibits pheromone signaling, apparently by increasing the pool of $\mathrm{G} \alpha$ available to associate with and inhibit $\mathrm{G} \beta \gamma$ (Cole et al., 1990). The analogous experiments in $C$. elegans with $\mathrm{G} \alpha_{0}$ give precisely the opposite results. $\mathrm{G} \alpha_{o}$ null mutations appear to result in a loss of signaling, not constitutive signaling (Mendel et al., 1995; Ségalat et al., 1995), and overexpression of wild-type $\mathrm{G \alpha}_{0}$ appears to result in constitutive signaling, not loss of signaling (Mendel et al., 1995). These results are exactly analogous to those obtained from genetic studies of $\mathrm{G \alpha}_{q}$ in C. elegans (Brundage et al., 1996), a case in which it is clear that downstream signaling is due to $\mathrm{G} \alpha$ effectors, not $\mathrm{G} \beta \gamma$ effectors.

Could it be that $\mathrm{G \alpha}_{0}$ signals by directly binding to and inhibiting adenylyl cyclase? Adenylyl cyclase is the effector directly activated by $\mathrm{G} \alpha_{\mathrm{s}}$ (see Section 3.3.), and it can also be directly bound and inhibited by members of the $G \alpha_{i / o}$ family of $G \alpha$ proteins, at least in cultured cells. Indeed, $G \alpha_{0}$ overexpressed in cultured cells has been shown to inhibit one isoform of adenylyl cyclase (Näsman et al., 2002). While this hypothesis is intriguing, there is currently no genetic evidence that inhibition of adenylyl cyclase is a physiologically relevant mechanism for $G \alpha_{o}$ signaling. If $G \alpha_{o}$ signaled by inhibiting adenylyl cyclase, we might expect that $G \alpha_{o}$ and $G \alpha_{s}$ signaling would show precisely opposite effects in C. elegans genetic experiments. However, this is not the case (see Section 3.3), and G $\alpha_{\circ}$ signaling rather shows far more precise opposition to the effects of $\mathrm{G \alpha}_{q}$ signaling.

Could it be that $\mathrm{G} \alpha_{o}$ signals by directly binding to and regulating one of the components of the $G \alpha_{q}$ signaling pathway, thus neatly solving the problem of identifying the $\mathrm{G} \alpha_{0}$ effector and explaining how $\mathrm{G} \alpha_{0}$ signaling opposes $\mathrm{G} \alpha_{q}$ signaling (Section 3.5)? Two specific $G \alpha_{q}$ signaling pathway proteins (Figure 3) have been proposed as $G \alpha_{o}$ effectors: DGK and EAT-16. First, all genetic studies are consistent with the possibility that Go o could signal by activating diacylglycerol kinase (DGK), the enzyme that terminates $G \alpha_{q}$ signaling by destroying the $G \alpha_{q}$ second messenger diacylglycerol. However, all efforts to demonstrate a biochemical effect of G $\alpha_{o}$ on DGK activity have 
proven negative (Jose and Koelle, 2005; Perez-Mansilla and Nurrish, 2009). The second hypothesis is that the effector for $\mathrm{G} \alpha_{o}$ could be the $\mathrm{G} \alpha_{\mathrm{q}}$-specific RGS protein EAT-16. An elegant model based on both genetic analysis and structural features of the EAT-16 protein complex proposes that inactive $G \alpha_{o}$ sequesters EAT-16, and activation of $\mathrm{G} \alpha_{0}$ releases EAT-16 to inhibit $\mathrm{G} \alpha_{q}$ (Robatzek et al., 2001). However, no biochemical studies of either the $C$. elegans proteins nor their mammalian equivalents has produced any support for this model.

If $\mathrm{G} \alpha_{0}$ indeed signals directly through its own effectors, why have these effectors not yet been identified? Known effectors for other $G$ proteins are often multi-subunit membrane protein complexes, and the cDNA expression library screening methods that have been employed in attempts to identify $G \alpha_{o}$ effectors (Chen et al., 1999; Takesono et al., 1999; Cuppen et al., 2003) are not well suited for finding such proteins. Genetic screens in $C$. elegans for $\mathrm{G} \alpha_{0}$ signaling proteins would have failed to identify $\mathrm{G} \alpha_{0}$ effectors if there are multiple redundant effectors, such that mutating a single effector gene causes little reduction in $G \alpha_{o}$ signaling. In addition, if a $G \alpha_{o}$ effector is essential for viability or reproduction, mutating such an effector would not produce animals that could be detected and recovered in a genetic screen. Because there are perfectly reasonable explanations why a $\mathrm{G} \alpha_{o}$ effector may have eluded discovery, the absence of such a discovery at this point should not be taken as evidence that $G \alpha_{\circ}$ effectors do not exist.

\subsection{The relationship between $\mathrm{G} \alpha_{\mathfrak{q}}, \mathrm{G} \alpha_{s}$, and $\mathrm{G} \alpha_{\mathrm{o}}$ signaling}

$G \alpha_{q}, G \alpha_{s}$, and $G \alpha_{o}$ signaling all operate at the same time in the same neurons, and Figure 2 presents a model showing them acting in parallel to each other until they intersect downstream by ultimately all regulating neurotransmitter release. However, genetic epistasis experiments have been used to examine the relationship between the three $G$ protein signaling pathways, and other relationships between the $G$ protein signaling pathways are also consistent with these genetic results.

Double mutants for $\mathrm{G} \alpha_{q}$ and $\mathrm{G} \alpha_{o}$ resemble $\mathrm{G} \alpha_{q}$ single mutants, and this and results from other double-mutant combinations are consistent with the interpretation that $\mathrm{G} \alpha_{o}$ signaling acts to inhibit $\mathrm{G} \alpha_{q}$ signaling (Hajdu-Cronin et al., 1999; Miller et al., 1999; Charlie et al., 2006a). More specifically, this means that $\mathrm{G} \alpha_{\mathrm{o}}$ signaling could inhibit the $\mathrm{G} \alpha_{q}$ pathway at any level, upstream of $\mathrm{G \alpha}_{\mathfrak{q}}$, at the level of $\mathrm{G \alpha}_{\mathrm{q}}$, or at any level downstream of $\mathrm{G \alpha}_{\mathrm{q}}$. Only molecular experiments will ultimately be able to distinguish between these possibilities.

The relationship between $\mathrm{G} \alpha_{\mathrm{s}}$ and $\mathrm{G} \alpha_{\mathrm{q}}$ signaling has been investigated by combining mutations that increase signaling in one pathway with mutations that block signaling in the other pathway (Reynolds et al., 2005; Charlie et al., 2006a). This was done in both directions (i.e., a $\mathrm{G} \alpha_{\text {s }}$ pathway gain-of-function mutation combined with a $G \alpha_{q}$ null mutation, and also a $\mathrm{G} \alpha_{q}$ gain-of-function mutation combined with a $\mathrm{G} \alpha_{\mathrm{s}}$ pathway null mutation). The results of these experiments do not yield a simple epistatic relationship between the two signaling pathways, but do yield several important insights. First, the $\mathrm{G} \alpha_{\mathrm{s}}$ pathway is virtually completely dependent on the $\mathrm{G} \alpha_{\mathrm{q}}$ pathway to exert its effects on locomotion (Reynolds et al., 2005). Second, the $G \alpha_{q}$ pathway can still promote locomotion in the absence of a functional $\mathrm{G} \alpha_{\mathrm{s}}$ pathway, but the resulting locomotion is uncoordinated (Reynolds et al., 2005). Third, phorbol esters (analogs of the DAG ultimately produced by the $\mathrm{G} \alpha_{q}$ pathway) can also promote uncoordinated locomotion in the absence of a functional $G \alpha_{s}$ pathway, suggesting $G \alpha_{s}$ signaling regulates locomotion downstream of DAG production (Reynolds et al., 2005). Fourth, the $\mathrm{G} \alpha_{\mathrm{q}}$ and $\mathrm{G} \alpha_{\mathrm{s}}$ pathways have distinct effects in driving locomotion, one line of evidence for which is that loss of $G \alpha_{q}$ signaling appears to strongly reduce acetylcholine release from motor neurons while loss of $\mathrm{G} \alpha_{\mathrm{s}}$ signaling does not (Charlie et al., 2006a).

\subsection{Receptor-independent activation of heterotrimeric G proteins}

An important contribution of the $C$. elegans system was the discovery of the receptor-independent $G \alpha$ chaperone and activator RIC-8, which was first identified in a genetic screen for mutants with reduced acetylcholine release from ventral cord motor neurons (Miller et al., 1996). Genetic studies showed that reduction of function mutations in RIC-8 and G $\alpha_{q}$ have similar phenotypes and were consistent with RIC-8 acting upstream of G $\alpha_{q}$ to promote $\mathrm{G} \alpha_{\mathrm{q}}$ signaling (Miller et al., 2000). Subsequent genetic studies demonstrated that RIC-8 also appears to promote $\mathrm{G} \alpha_{\mathrm{s}}$ signaling (Reynolds et al., 2005) and $\mathrm{G} \alpha_{o}$ signaling (Miller and Rand, 2000; Hofler and Koelle, 2011).

Biochemical studies of mammalian RIC- 8 have identified two mechanisms by which RIC-8 can promote G $\alpha$ signaling. First, RIC- 8 can act as a nucleotide exchange factor to convert inactive G $\alpha$-GDP to active G $\alpha$-GTP (Tall et al., 2003; Chan et al., 2011). Unlike GPCRs, which are transmembrane proteins that act as nucleotide exchange factors to activate G $\alpha \beta \gamma$ heterotrimers, RIC- 8 is a soluble protein and will not act on the heterotrimer, but rather can

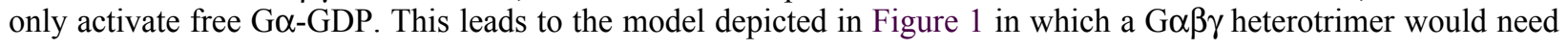


to initially be activated by a GPCR to generate G $\alpha$-GTP, but after GTP hydrolysis the inactive G $\alpha$-GDP produced might be reactivated by the nucleotide exchange activity of RIC-8, thus prolonging signaling.

The second mechanism by which RIC- 8 can activate G $\alpha$ signaling is by simply stabilizing G $\alpha$ proteins. Knocking out RIC-8 in mammalian cells causes dramatic reductions in the levels of G $\alpha$ proteins (Gabay et al., 2011). Biochemical studies show RIC-8 acts as a chaperone to help fold nascent Go proteins (Chan P. et al., 2013). It has not yet been determined if RIC-8 mutations in C. elegans similarly cause reductions of G $\alpha$ protein levels. The genetics of RIC- 8 are consistent with RIC- 8 promoting G $\alpha$ signaling either by simply stabilizing G $\alpha$ proteins, by acting as a nucleotide exchange factor, or by both mechanisms.

Another type of receptor-independent activator for $G \alpha_{o}$ are proteins containing a short motif that binds

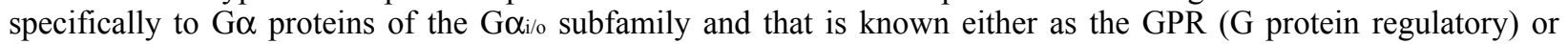
GoLoco motif (Siderovski et al., 1999; Peterson et al., 2000). C. elegans has three such proteins. The two very similar and functionally redundant GPR-1 and GPR-2 proteins act in early embryonic cells with Go o to regulate spindle positioning during asymmetric cell divisions (Colombo et al., 2003; Gotta et al., 2003; Srinivasan et al., 2003). The AGS-3 protein acts with Goo to regulate function of adult neurons (Hofler and Koelle, 2011). Biochemical studies of mammalian GPR/GoLoco proteins emphasize the fact that when these proteins bind G $\alpha$-GDP, they inhibit nucleotide exchange, which would suggest that they prevent formation of active G $\alpha$-GTP and thus inhibit signaling (Siderovski et al., 1999; Peterson et al., 2000). However, C. elegans genetic studies clearly demonstrate that precisely the opposite is true, since GPR-1/2 promote G $\alpha_{0}$ activity in embryonic cell divisions and AGS-3 also promotes Go signaling in adult neurons (Colombo et al., 2003; Gotta et al., 2003; Srinivasan et al., 2003; Hofler and Koelle, 2011). The apparent conflict between these results can be resolved by the findings that all known functions of the GPR/GoLoco proteins in C. elegans also require RIC-8, along with the biochemical result that RIC-8 can act as a nucleotide exchange factor on the complex between G $\alpha_{0}$-GDP and a GPR/GoLoco protein to produce active $\mathrm{G} \alpha_{0}$-GTP (Thomas et al., 2008). Thus an attractive model is that when active $G \alpha_{0}$-GTP hydrolyzes

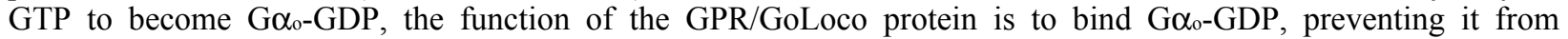
reassociating with G $\beta \gamma$, which would have terminated signaling, and rather to present G $\alpha_{0}$-GDP to RIC-8 for nucleotide exchange to convert it back to active G $\alpha_{0}$-GTP (Figure 1). The net result would be to prolong signaling that had been initiated earlier by a GPCR.

The C. elegans GPR/GoLoco protein AGS-3 is of particular interest as it has a close mammalian brain ortholog, AGS3, and a role in mediating behavioral response to food deprivation. AGS-3 is expressed in most or all C. elegans neurons and is required for several different behavioral changes that normally occur in response to short-term food deprivation (Hofler and Koelle, 2011). Biochemical studies show that over the first few hours of food deprivation, AGS-3 protein from $C$. elegans lysates changes from a detergent-insoluble form to a detergent-solubilizable form, indicating that a physical change in the protein occurs. These results lead to a model in which food deprivation leads to a physical change in AGS-3, allowing it to activate $\mathrm{G}_{0}$ signaling to induce behavioral changes appropriate for the food-deprived state of the animal. It will be fascinating to see if this role of AGS-3 in mediating response to food deprivation is conserved in mammals (Hofler and Koelle, 2012).

\subsection{Regulators of $G$ protein signaling inhibit $G \alpha_{\circ}$ and $G \alpha_{q}$ signaling}

Another important contribution of the C. elegans system was the discovery and characterization of the family of Regulator of G protein Signaling (RGS) proteins. The first RGS protein, Sst2p, was identified in yeast (Dietzel and Kurjan, 1987), but it was not clear that it had any homologs in higher eukaryotes. Genetic studies identified the C. elegans RGS protein EGL-10 as an inhibitor of Go signaling, and comparison of Sst2p and EGL-10 allowed the discovery of an "RGS domain" conserved between the two and that is also found in a large family of proteins in $C$. elegans and mammals (Koelle and Horvitz, 1996). Biochemical studies showed that the RGS domain binds directly to $\mathrm{G} \alpha$ proteins, and by stabilizing the transition state for GTP hydrolysis, inactivates signaling by driving the

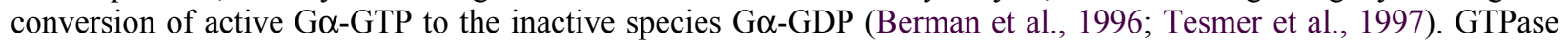
activators were previously known for the small ras-like G proteins, which have structural similarity to the GTPase domain of $\mathrm{G} \alpha$ proteins but lack a catalytic arginine residue that $\mathrm{G} \alpha$ proteins use for GTP hydrolysis. Thus small $\mathrm{G}$ proteins are unable to convert GTP to GDP at a meaningful rate without first binding a GTPase activating protein that inserts an arginine residue into their active site ( $\mathrm{Li}$ and Zhang, 2004). In contrast, $\mathrm{G} \alpha$ subunits of heterotrimeric G proteins were initially thought to not require help from any GTPase activating proteins to convert to their inactive GDP-bound state, since they have an intrinsic GTPase activity orders of magnitude faster than that of small GTPases. However, genetic studies in C. elegans show that in vivo, the $\mathrm{G} \alpha_{o}$ and $\mathrm{G} \alpha_{\mathrm{q}}$ proteins require RGS proteins to appropriately terminate signaling (Koelle and Horvitz, 1996; Hajdu-Cronin et al., 1999). In contrast, neither genetic studies in worms nor biochemical studies of mammalian proteins have identified a GTPase activator for Gos. Thus $\mathrm{G} \alpha_{s}$ may indeed simply use its slow intrinsic GTPase activity to terminate signaling. 
The two most intensively studied RGS proteins in C. elegans are EGL-10 and EAT-16, which serve as specific inhibitors of $\mathrm{G} \alpha_{o}$ and $\mathrm{G} \alpha_{q}$ signaling, respectively (Koelle and Horvitz, 1996; Hajdu-Cronin et al., 1999). They are members of the R7 family of RGS proteins, of which there are four members in mammals that are expressed in the brain (Anderson et al., 2009). In vitro, these mammalian R7 proteins all preferentially inactivate $\mathrm{G} \alpha_{o}$ rather than $\mathrm{G} \alpha_{\mathrm{q}}$, and it is unclear if any of them might actually be $\mathrm{G} \alpha_{\mathrm{q}}$ specific in vivo, like C. elegans EAT-16. Analysis of chimeras between EGL-10 and EAT-16 shows that the $G \alpha_{0}$ versus $G \alpha_{q}$ specificity of these proteins lies in an N-terminal domain that remains of unknown biochemical function (Patikoglou and Koelle, 2002). The $C$. elegans R7 RGS proteins, like their mammalian homologs, contain a $\mathrm{G} \gamma$-like domain that is constitutively bound to a G $\beta$-like protein known as G $\beta_{5}$ in mammals and GPB-2 in C. elegans (Chase et al., 2001; Robatzek et al., 2001; van der Linden et al., 2001). Thus the R7 RGS/G $\beta$ complex in many respects resembles a G $\beta \gamma$ complex, but there is as yet no understanding of what this means or how it might be used. EAT-16, like the mammalian R7 RGS proteins, is anchored to the plasma membrane via a lipid-modified membrane anchoring subunit (Porter and Koelle, 2009). There is no known membrane anchor for EGL-10.

There are at least 13 RGS proteins in C. elegans, and the genes for all have been knocked out and studied (reviewed by Porter and Koelle, 2009). While the R7 family RGS proteins EGL-10 and EAT-16 are widely expressed, and mutants cause severe disruption of $\mathrm{G}$ protein signaling and behavior, the other RGS proteins appear to have much more specific functions. For example, RGS-3 is expressed only in a subset of sensory neurons, where it dampens signaling in response to strong stimuli, increasing the dynamic range for sensing these stimuli (Ferkey et al., 2007). RGS-1, RGS-2, and RGS-7 are all inhibitors of G $\alpha_{\circ}$, but have much more limited functions than does the main $G \alpha_{0}$ inhibitor EGL-10. RGS-7 is expressed in early embryos where it regulates the function of $G \alpha_{0}$ in controlling asymmetric cell divisions (Hess et al., 2004). RGS-1 and RGS-2 are very similar to each other and are functionally redundant (Dong et al., 2000). Knocking out both disrupts a specific behavioral response that occurs when starved animals are re-fed. Knockouts for a number of additional RGS genes so far have shown no detectable defects, suggesting that these RGS genes, like RGS-1 and RGS-2, may have redundant and/or very specific functions that will be difficult to define.

\subsection{Reconciling studies of neural $\mathrm{G} \alpha$ signaling in $C$. elegans with those in more complex model organisms}

The studies in $C$. elegans reviewed above show that the molecular details of the $\mathrm{G} \alpha_{\mathrm{q}}, \mathrm{G} \alpha_{\mathrm{s}}$, and $\mathrm{G} \alpha_{\mathrm{o}}$ signaling pathways, to the extent they are known, are the same in $C$. elegans versus the other invertebrate and vertebrate systems in which they have been studied, until we get down to the very most downstream outputs of these signaling pathways. The C. elegans work has been focused largely on the effects of the G proteins in ventral cord motor neurons on locomotion behavior and in the HSN neurons on egg-laying behavior. Using these two behaviors as readouts, the relevant outputs of signaling that have been identified are changes in the efficiency of the neurotransmitter release machinery. All the proteins involved in these changes are highly conserved across evolution, and functional studies in mammalian neurons support the idea that the very same mechanisms are used in mammalian brain to allow G protein signaling to modulate neurotransmitter release (Rhee et al., 2002; Wierda et al., 2007).

Studies of neural $\mathrm{G}$ protein signaling in more complex model organisms have focused on readouts of signaling very different from those used in C. elegans. When electrophysiological measurements have been used to measure signaling outcomes, the focus has been on the regulation of specific ion channels by G $\beta \gamma$ subunits (Reuveny et al., 1994; Herlitze et al., 1996), and indeed some of the effects of neural G protein signaling in C. elegans are mediated by such ion channels (Emtage et al., 2012). When effects on long-term memories have been the readout of signaling, the focus has been on the lasting effects of neural $G$ protein signaling on synaptic structure or on transcription (Kandel, 2004). It is not yet fully clear whether neural G protein signaling in C. elegans results in these sorts of lasting changes. We do know that $\mathrm{G \alpha}_{q}$ signaling in worms, as in mammals, results in activation of the Rho GTPase, whose best-studied function is as a regulator of the actin cytoskeleton, but it remains to be seen if $\mathrm{G} \alpha_{\mathrm{q}}$ signaling through Rho leads to functionally significant and lasting structural changes in C. elegans synapses. In Aplysia and mammals, $G \alpha_{s}$ signaling produces cAMP that activates the transcription factor CREB to induce changes in transcription that may underlie long-term memories (Kida et al., 2002; Kandel, 2012), although the relevance of CREB is less clear in Drosophila memory (Perazzona et al., 2004). C. elegans also has a CREB homolog that was shown to be essential for worms to form a long-term memory of a food-odorant association (Kauffman et al., 2010) and that mediates $G$ protein regulation of gene expression (Suo et al,. 2006). Thus it seems likely that the mechanisms of neural G protein signaling are deeply conserved across evolution, but that the different types of behavioral readouts used to study such signaling in different model organisms tends to focus attention on different downstream effects of the signaling pathways on neural function. 


\section{Concluding remarks and future directions}

Finally, I return to the simplified model presented in Figure 2 to illustrate an overview of what has been learned from studies of neurotransmitter signaling through heterotrimeric $\mathrm{G}$ proteins in C. elegans. As described in Section 2, a typical neuron expresses many GPCRs, and these receptors sense the levels of neurotransmitters that are released, not just from presynaptic partners to our typical neuron, but also from distant neurons and are thus acting extrasynaptically. Each neurotransmitter and its receptor are expressed in very specific and small sets of neurons, and the extrasynaptic communication between these cells is a crucial type of functional connection that goes beyond the physical synaptic connections between neurons and that is essential for understanding neural circuits. As described in Section 3, three different $\mathrm{G} \alpha$ proteins, $\mathrm{G} \alpha_{\mathrm{q}}, \mathrm{G} \alpha_{\mathrm{s}}$, and $\mathrm{G} \alpha_{\mathrm{o}}$, integrate signaling by the many GPCRs that may be active on a neuron at any one time. The major outcomes of neural $\mathrm{G}$ protein signaling studied in C. elegans are the opposing effects that $G \alpha_{q}$ and $G \alpha_{o}$ have to activate and inhibit the synaptic vesicle release machinery, respectively. $G \alpha_{s}$ signaling collaborates with the $G \alpha_{q}$ pathway to promote synaptic output. Other outcomes of $G \alpha$ activation, such as regulation of $\mathrm{K}^{+}$and $\mathrm{Ca}^{2+}$ channels, or effects on neural structure or transcription, also seem to occur but are not responsible for the most obvious effects of the $\mathrm{G}$ proteins on C. elegans behavior. The neurotransmitters, receptors, G proteins, downstream signaling molecules, and mechanisms used in C. elegans are all conserved in mammals. The contribution of $C$. elegans studies has been to focus attention on the ubiquity of extrasynaptic signaling through GPCRs, the effects of neural G proteins on the neurotransmitter release machinery, and on new signaling molecules such as RIC-8, TrioRhoGEF, and RGS proteins that were discovered in C. elegans using the power of forward genetic screens.

Opportunities for future progress using $C$. elegans include the chance to grapple with the huge family of GPCRs that activate neural G proteins. Perhaps the entire set of GPCRs expressed on some model neurons, such as the ventral cord motor neurons or the HSN egg-laying neurons, can be defined and used to study how these receptors act together to regulate activity of these neurons. More work remains to define the mechanisms by which the three major neural $G$ proteins affect neurotransmitter release, and at what level they intersect. In particular, the effector for $\mathrm{G \alpha}_{o}$, if it exists, still remains to be identified. Finally, it remains to be seen whether C. elegans can be used to successfully study the types of changes in synaptic structure and transcription that occur downstream of $\mathrm{G}$ proteins in neurons of more complex organisms.

\section{Acknowledgements}

I thank Judy Pepper and Jacob Brewer for preparing the video shown as Movie 1, Robert Fernandez for providing research for Table 1 and Table 2, and Seongseop Kim, Robert Fernandez, and Andrew Olson for critically reading the manuscript. Work in the Koelle lab is supported by grants R01NS036918 and R01NS086932 from the NIH.

\section{Table 1 and Table 2}

Table 1. G protein coupling and pharmacological profiles of $C$. elegans $\mathbf{G}$ protein coupled small molecule neurotransmitter receptors

\begin{tabular}{|l|l|l|l|l|l|l|}
\hline $\begin{array}{l}\text { Serotonin } \\
\text { receptors }\end{array}$ & $\begin{array}{l}\text { Experimental } \\
\text { evidence for } \\
\text { ligand } \\
\text { assignment }\end{array}$ & $\begin{array}{l}\text { G protein } \\
\text { coupling }\end{array}$ & $\begin{array}{l}\text { References G } \\
\text { protein } \\
\text { coupling }\end{array}$ & $\begin{array}{l}\text { References } \\
\text { binding } \\
\text { studies }\end{array}$ & $\begin{array}{l}\text { Agonists } \\
\text { (EC50) in } \\
\text { heterologous } \\
\text { cells }\end{array}$ & $\begin{array}{l}\text { References } \\
\text { heterologous } \\
\text { cell studies }\end{array}$ \\
\hline SER-1 & $\begin{array}{l}\text { Binding } \\
\text { studies, } \\
\text { heterologous } \\
\text { cell signaling, } \\
\text { mutant } \\
\text { resistant to } \\
\text { serotonin }\end{array}$ & $\begin{array}{l}\text { Go } \alpha_{q} \text { in } \\
\text { heterologous } \\
\text { cells }\end{array}$ & $\begin{array}{l}\text { Hamdan et al., } \\
1999\end{array}$ & $\begin{array}{l}\text { Hamdan et al., } \\
1999\end{array}$ & $\begin{array}{l}\text { Serotonin } \\
\left(\begin{array}{l}0.72 \text { and } \\
0.8 \mu \mathrm{M}), \\
\text { lisuride } \\
\text { (partial, 0.2 } \\
\text { and 2.4 } \mu \mathrm{M}), \\
\text { DOI (partial, } \\
>100 \mu \mathrm{M}) . \text { No } \\
\text { activity with } \\
\text { dopamine or } \\
\text { octopamine. }\end{array}\right.\end{array}$ & $\begin{array}{l}\text { Hamdan et al., } \\
1999\end{array}$ \\
\hline
\end{tabular}


Neurotransmitter signaling through heterotrimeric $\mathrm{G}$ proteins: insights from studies in C. elegans

\begin{tabular}{|c|c|c|c|c|c|c|}
\hline SER-4 & $\begin{array}{l}\text { Binding } \\
\text { studies, } \\
\text { heterologous } \\
\text { cell signaling, } \\
\text { mutant } \\
\text { resistant to } \\
\text { serotonin }\end{array}$ & \begin{tabular}{|l}
$\mathrm{G \alpha}_{\mathrm{i} /}$ in \\
heterologous \\
cells
\end{tabular} & $\begin{array}{l}\text { Olde and } \\
\text { McCombie, } \\
1997\end{array}$ & $\begin{array}{l}\text { Olde and } \\
\text { McCombie, } \\
1997\end{array}$ & $\begin{array}{l}\text { Serotonin } \\
(\sim 0.1 \mu \mathrm{M}), \\
\text { tyramine }\end{array}$ & $\begin{array}{l}\text { Olde and } \\
\text { McCombie, } \\
1997 ; \\
\text { Petrascheck et } \\
\text { al., } 2007\end{array}$ \\
\hline SER-5 & $\begin{array}{l}\text { Mutant } \\
\text { resistant to } \\
\text { serotonin }\end{array}$ & $\begin{array}{l}\text { Gos predicted } \\
\text { from sequence } \\
\text { analysis }\end{array}$ & $\begin{array}{l}\text { Harris et al., } \\
2009\end{array}$ & & & \\
\hline SER-7 & \begin{tabular}{|l} 
Binding \\
studies, \\
heterologous \\
cell signaling, \\
mutant \\
resistant to \\
serotonin
\end{tabular} & 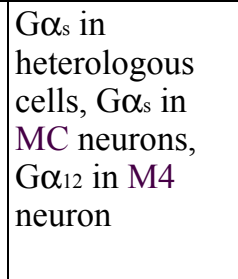 & $\begin{array}{l}\text { Hobson et al., } \\
\text { 2003; Hobson } \\
\text { et al., 2006; } \\
\text { Song and } \\
\text { Avery, } 2012\end{array}$ & $\begin{array}{l}\text { Hobson et al., } \\
\text { 2003; Hobson } \\
\text { et al., } 2006\end{array}$ & $\begin{array}{l}\text { Serotonin } \\
(30 \mathrm{nM}), \\
\text { tryptamine } \\
(4.7 \mu \mathrm{M})\end{array}$ & $\begin{array}{l}\text { Hobson et al., } \\
\text { 2003; Hobson } \\
\text { et al., } 2006\end{array}$ \\
\hline $\begin{array}{l}\text { Dopamine } \\
\text { receptors }\end{array}$ & $\begin{array}{l}\text { Experimental } \\
\text { evidence for } \\
\text { ligand } \\
\text { assignment }\end{array}$ & $\begin{array}{l}\text { G protein } \\
\text { coupling }\end{array}$ & $\begin{array}{l}\text { References G } \\
\text { protein } \\
\text { coupling }\end{array}$ & $\begin{array}{l}\text { References } \\
\text { binding } \\
\text { studies }\end{array}$ & $\begin{array}{l}\text { Agonists } \\
(\text { EC50) in } \\
\text { heterologous } \\
\text { cells }\end{array}$ & $\begin{array}{l}\text { References } \\
\text { heterologous } \\
\text { cell studies }\end{array}$ \\
\hline DOP-1 & \begin{tabular}{|l} 
Binding \\
studies, \\
mutation \\
affects \\
dopamine \\
response
\end{tabular} & $\begin{array}{l}\mathrm{G} \alpha_{\mathrm{q}} \text { in ventral } \\
\text { cord motor } \\
\text { neurons and } \\
\text { touch response } \\
\text { neurons }\end{array}$ & $\begin{array}{l}\text { Chase et al., } \\
\text { 2004; Kindt et } \\
\text { al., 2007 }\end{array}$ & Suo et al., 2002 & & \\
\hline DOP-2 & $\begin{array}{l}\text { Binding } \\
\text { studies, mutant } \\
\text { resistant to } \\
\text { dopamine, } \\
\text { heterologous } \\
\text { cell signaling }\end{array}$ & $\begin{array}{l}\text { Go } \alpha_{\mathrm{i} / \mathrm{o}} \text { in } \\
\text { heterologous } \\
\text { cells, GOA-1 } \\
\text { in SIA } \\
\text { neurons, } \\
\text { GPA-14 in } \\
\text { yeast } \\
\text { interaction } \\
\text { assay and ADE } \\
\text { neurons. } \\
\text { GOA-1 and } \\
\text { GPA-7 in male } \\
\text { mating. }\end{array}$ & $\begin{array}{l}\text { Suo et al., } \\
\text { 2003; Suo et } \\
\text { al., 2009; } \\
\text { Correa et al., } \\
\text { 2012; Pandey } \\
\text { and Harbinder, } \\
\text { 2012; Mersha } \\
\text { et al., 2013 }\end{array}$ & Suo et al., 2003 & $\begin{array}{l}\text { dopamine } \\
(75 \mathrm{nM})\end{array}$ & Suo et al., 2003 \\
\hline DOP-3 & $\begin{array}{l}\text { Mutant } \\
\text { resistant to } \\
\text { dopamine, } \\
\text { heterologous } \\
\text { cell signaling }\end{array}$ & $\begin{array}{l}\mathrm{G} \alpha_{\mathrm{o}} \text { in ventral } \\
\text { cord motor } \\
\text { neurons, } \mathrm{G} \alpha_{\mathrm{i} / \mathrm{o}} \\
\text { in heterologous } \\
\text { cells }\end{array}$ & $\begin{array}{l}\text { Chase et al., } \\
\text { 2004; Sugiura } \\
\text { et al., } 2005\end{array}$ & & $\begin{array}{l}\text { dopamine } \\
(27 \mathrm{nM}), \\
\text { tyramine } \\
(500 \mathrm{nM}), \\
\text { octopamine } \\
(250 \mu \mathrm{M})\end{array}$ & $\begin{array}{l}\text { Sugiura et al., } \\
2005\end{array}$ \\
\hline DOP-4 & \begin{tabular}{|l|} 
Mutant \\
resistant to \\
dopamine, \\
heterologous \\
cell signaling
\end{tabular} & \begin{tabular}{|l|} 
Gos in \\
heterologous \\
cells
\end{tabular} & $\begin{array}{l}\text { Sugiura et al., } \\
2005\end{array}$ & & $\begin{array}{l}\text { dopamine } \\
(9.3 \mu \mathrm{M}), \\
>1 \mathrm{mM} \text { for } \\
\text { dopamine, } \\
\text { octopamine, } \\
\text { tyramine and } \\
\text { serotonin }\end{array}$ & $\begin{array}{l}\text { Sugiura et al., } \\
2005\end{array}$ \\
\hline
\end{tabular}


Neurotransmitter signaling through heterotrimeric G proteins: insights from

studies in C. elegans

\begin{tabular}{|c|c|c|c|c|c|c|}
\hline $\begin{array}{l}\text { Octopamine } \\
\text { receptors }\end{array}$ & $\begin{array}{l}\text { Experimental } \\
\text { evidence for } \\
\text { ligand } \\
\text { assignment }\end{array}$ & $\begin{array}{l}\text { G protein } \\
\text { coupling }\end{array}$ & $\begin{array}{l}\text { References G } \\
\text { protein } \\
\text { coupling }\end{array}$ & $\begin{array}{l}\text { References } \\
\text { binding } \\
\text { studies }\end{array}$ & $\begin{array}{l}\text { Agonists } \\
(\text { EC50) in } \\
\text { heterologous } \\
\text { cells }\end{array}$ & \begin{tabular}{|l} 
References \\
heterologous \\
cell studies
\end{tabular} \\
\hline OCTR-1 & \begin{tabular}{|l|} 
Binding \\
studies, \\
heterologous \\
cell signaling, \\
mutant \\
resistant to \\
octopamine
\end{tabular} & $\begin{array}{l}\text { G } \alpha_{\mathrm{o}} \text { in } \mathrm{ASH} \\
\text { neurons, G } \alpha_{\mathrm{o}} \\
\text { in heterologous } \\
\text { cells }\end{array}$ & $\begin{array}{l}\text { Harris et al., } \\
2010\end{array}$ & $\begin{array}{l}\text { Wragg et al., } \\
2007\end{array}$ & $\begin{array}{l}\text { octopamine } \\
(0.39 \mu \mathrm{M} \text { in } \\
\text { Xenopus } \\
\text { oocytes, but } \\
\text { binding studies } \\
\text { suggest higher } \\
\text { affinity) }\end{array}$ & $\begin{array}{l}\text { Mills et al., } \\
2012\end{array}$ \\
\hline SER-3 & \begin{tabular}{|l|} 
Mutant \\
resistant to \\
octopamine, \\
heterologous \\
cell signaling
\end{tabular} & $\begin{array}{l}\text { Go } \alpha_{q} \text { in ASH } \\
\text { neurons, G } \alpha_{q} \\
\text { in heterologous } \\
\text { cells }\end{array}$ & Suo et al., 2006 & & \begin{tabular}{|l|} 
octopamine \\
$(24 \mathrm{nM}$ in \\
mammalian \\
cells; $0.33 \mu \mathrm{M}$ \\
in Xenopus \\
oocytes $)$ \\
tyramine \\
$(26 \mu \mathrm{M}$ in \\
mammalian \\
cells $)$
\end{tabular} & $\begin{array}{l}\text { Petrascheck et } \\
\text { al., 2007; Mills } \\
\text { et al., 2012 }\end{array}$ \\
\hline SER-6 & $\begin{array}{l}\text { Mutant } \\
\text { resistant to } \\
\text { octopamine }\end{array}$ & $\begin{array}{l}\text { Gos in ADL } \\
\text { neurons }\end{array}$ & $\begin{array}{l}\text { Mills et al., } \\
\text { 2012; }\end{array}$ & & $\begin{array}{l}\text { octopamine } \\
(2 \mu \mathrm{M} \text { in } \\
\text { Xenopus } \\
\text { oocytes })> \\
\text { tyramine. No } \\
\text { response to } \\
\text { dopamine or } \\
\text { serotonin. }\end{array}$ & $\begin{array}{l}\text { Mills et al., } \\
\text { 2012; }\end{array}$ \\
\hline $\begin{array}{l}\text { Tyramine } \\
\text { receptors }\end{array}$ & $\begin{array}{l}\text { Experimental } \\
\text { evidence for } \\
\text { ligand } \\
\text { assignment }\end{array}$ & $\begin{array}{l}\text { G protein } \\
\text { coupling }\end{array}$ & $\begin{array}{l}\text { References G } \\
\text { protein } \\
\text { coupling }\end{array}$ & $\begin{array}{l}\text { References } \\
\text { binding } \\
\text { studies }\end{array}$ & $\begin{array}{l}\text { Agonists } \\
(\text { EC50) in } \\
\text { heterologous } \\
\text { cells }\end{array}$ & \begin{tabular}{|l} 
References \\
heterologous \\
cell studies
\end{tabular} \\
\hline SER-2 & $\begin{array}{l}\text { heterologous } \\
\text { cell signaling, } \\
\text { mutant } \\
\text { resistant to } \\
\text { tyramine }\end{array}$ & $\begin{array}{l}G \alpha_{i / o} \text { in } \\
\text { heterologous } \\
\text { cells, G } \alpha_{0} \text { in } \\
\text { VD neurons }\end{array}$ & $\begin{array}{l}\text { Rex and } \\
\text { Komuniecki, } \\
\text { 2002; Donelly } \\
\text { et al., } 2013\end{array}$ & $\begin{array}{l}\text { Rex and } \\
\text { Komuniecki, } \\
2002\end{array}$ & $\begin{array}{l}\text { Tyramine } \\
360 \mathrm{nM}, \\
403 \mathrm{nM})\end{array}$ & \begin{tabular}{|l} 
Rex and \\
Komuniecki, \\
2002; Rex et \\
al., 2004
\end{tabular} \\
\hline TYRA-2 & $\begin{array}{l}\text { Binding } \\
\text { studies, } \\
\text { heterologous } \\
\text { cell signaling }\end{array}$ & $\begin{array}{l}\text { Go } \alpha_{\text {i/o }} \text { in } \\
\text { heterologous } \\
\text { cells }\end{array}$ & $\begin{array}{l}\text { Rex et al., } \\
2005\end{array}$ & $\begin{array}{l}\text { Rex et al., } \\
2005\end{array}$ & $\begin{array}{l}\text { Tyramine } \\
(50 \mathrm{nM}), \\
\text { octopamine } \\
\text { and dopamine } \\
\text { had little/no } \\
\text { effect }\end{array}$ & $\begin{array}{l}\text { Rex et al., } \\
2005\end{array}$ \\
\hline TYRA-3 & $\begin{array}{l}\text { Binding } \\
\text { studies, mutant } \\
\text { resistant to } \\
\text { tyramine }\end{array}$ & $\begin{array}{l}\text { Go } \alpha_{q} \text { in } \\
\text { heterologous } \\
\text { cells }\end{array}$ & $\begin{array}{l}\text { Hapiak et al., } \\
2013\end{array}$ & $\begin{array}{l}\text { Wragg et al., } \\
2007\end{array}$ & $\begin{array}{l}\text { tyramine } \\
(70.8 \mathrm{nM})\end{array}$ & $\begin{array}{l}\text { Hapiak et al., } \\
2013\end{array}$ \\
\hline
\end{tabular}




\begin{tabular}{|c|c|c|c|c|c|c|}
\hline $\begin{array}{l}\text { Acetylcholine } \\
\text { receptors }\end{array}$ & $\begin{array}{l}\text { Experimental } \\
\text { evidence for } \\
\text { ligand } \\
\text { assignment }\end{array}$ & $\begin{array}{l}\text { G protein } \\
\text { coupling }\end{array}$ & $\begin{array}{l}\text { References G } \\
\text { protein } \\
\text { coupling }\end{array}$ & $\begin{array}{l}\text { References } \\
\text { binding } \\
\text { studies }\end{array}$ & $\begin{array}{l}\text { Agonists } \\
(\text { EC50) in } \\
\text { heterologous } \\
\text { cells }\end{array}$ & \begin{tabular}{|l} 
References \\
heterologous \\
cell studies
\end{tabular} \\
\hline GAR-1 & $\begin{array}{l}\text { heterologous } \\
\text { cell signaling }\end{array}$ & $\begin{array}{l}\text { Go } \alpha_{\mathrm{i}} \text { in Xenopus } \\
\text { oocytes }\end{array}$ & $\begin{array}{l}\text { Park et al., } \\
2000\end{array}$ & & $\begin{array}{l}\text { Acetylcholine } \\
(\sim 100 \mathrm{nM}), \\
\text { carbachol, no } \\
\text { effect of } \\
\text { oxotremorine }\end{array}$ & $\begin{array}{l}\text { Park et al., } \\
2000\end{array}$ \\
\hline GAR-2 & $\begin{array}{l}\text { heterologous } \\
\text { cell signailng }\end{array}$ & \begin{tabular}{|l|}
$\mathrm{G \alpha}_{\mathrm{i} / \mathrm{o}}$ in \\
Xenopus \\
oocytes, $\mathrm{G} \alpha_{\mathrm{o}}$ in \\
ventral chord \\
cholinergic \\
neurons
\end{tabular} & $\begin{array}{l}\text { Lee et al., } \\
\text { 2000; Dittman } \\
\text { and Kaplan, } \\
2008\end{array}$ & & $\begin{array}{l}\text { acetylcholine } \\
(\sim 35 \mathrm{nM}), \\
\text { carbachol, no } \\
\text { effect of } \\
\text { oxotremorine }\end{array}$ & $\begin{array}{l}\text { Lee et al., } \\
\text { 2000; Suh et } \\
\text { al., 2001 }\end{array}$ \\
\hline GAR-3 & $\begin{array}{l}\text { heterologous } \\
\text { cell signaling, } \\
\text { mutant } \\
\text { resistant to } \\
\text { acetylcholine } \\
\text { agonist } \\
\text { arecoline }\end{array}$ & $\begin{array}{l}\mathrm{G} \alpha_{\mathrm{q}} \text { and } \mathrm{G} \alpha_{\mathrm{i} / \mathrm{o}} \\
\text { in heterologous } \\
\text { cells, } \mathrm{G} \alpha_{\mathrm{q}} \text { in } \\
\text { pharyngeal } \\
\text { muscles, } \mathrm{G} \alpha_{\mathrm{q}} \\
\text { in male spicule } \\
\text { protraction }\end{array}$ & $\begin{array}{l}\text { Min et al., } \\
\text { 2000; Park et } \\
\text { al., 2003; } \\
\text { Steger and } \\
\text { Avery 2004; } \\
\text { Park et al., } \\
\text { 2006; Liu et } \\
\text { al., 2007 }\end{array}$ & & $\begin{array}{l}\text { carbachol }(13.0 \\
\text { and } 11.5 \mu \mathrm{M}) \text {, } \\
\text { oxotremorine }\end{array}$ & $\begin{array}{l}\text { Hwang et al., } \\
\text { 1999; Min et } \\
\text { al., 2000; Park } \\
\text { et al., 2003 }\end{array}$ \\
\hline $\begin{array}{l}\text { GABA } \\
\text { receptors }\end{array}$ & $\begin{array}{l}\text { Experimental } \\
\text { evidence for } \\
\text { ligand } \\
\text { assignment }\end{array}$ & $\begin{array}{l}\text { G protein } \\
\text { coupling }\end{array}$ & $\begin{array}{l}\text { References G } \\
\text { protein } \\
\text { coupling }\end{array}$ & $\begin{array}{l}\text { References } \\
\text { binding } \\
\text { studies }\end{array}$ & $\begin{array}{l}\text { Agonists } \\
(\text { EC50) in } \\
\text { heterologous } \\
\text { cells }\end{array}$ & \begin{tabular}{|l|} 
References \\
heterologous \\
cell studies
\end{tabular} \\
\hline GBB-1 & \begin{tabular}{|l|} 
Mutant \\
insensitive to \\
optogenetically \\
released \\
GABA \\
\end{tabular} & \begin{tabular}{|l|} 
G $\alpha_{\mathrm{o}}$ in \\
cholinergic \\
motor neurons
\end{tabular} & $\begin{array}{l}\text { Dittman and } \\
\text { Kaplan, } 2008\end{array}$ & & & \\
\hline GBB-2 & \begin{tabular}{|l|} 
Mutant \\
insensitive to \\
optogenet-ically \\
released \\
GABA
\end{tabular} & $\begin{array}{l}\text { Go } \alpha_{\mathrm{o}} \text { in } \\
\text { cholinergic } \\
\text { motor neurons }\end{array}$ & $\begin{array}{l}\text { Dittman and } \\
\text { Kaplan, } 2008\end{array}$ & & & \\
\hline $\begin{array}{l}\text { Glutamate } \\
\text { receptor } \\
\text { homologs }\end{array}$ & $\begin{array}{l}\text { Experimental } \\
\text { evidence for } \\
\text { ligand } \\
\text { assignment }\end{array}$ & $\begin{array}{l}\text { G protein } \\
\text { coupling }\end{array}$ & $\begin{array}{l}\text { References G } \\
\text { protein } \\
\text { coupling }\end{array}$ & $\begin{array}{l}\text { References } \\
\text { binding } \\
\text { studies }\end{array}$ & $\begin{array}{l}\text { Agonists } \\
(\text { EC50) in } \\
\text { heterologous } \\
\text { cells }\end{array}$ & $\begin{array}{l}\text { References } \\
\text { heterologous } \\
\text { cell studies }\end{array}$ \\
\hline MGL-1 & $\begin{array}{l}\text { Mutant } \\
\text { resistant to } \\
\text { mGluR } \\
\text { agonists } \\
\text { trans-ACPD } \\
\text { and LCCG-I }\end{array}$ & & & & & \\
\hline MGL-2 & $\begin{array}{l}\text { heterologous } \\
\text { cell signaling }\end{array}$ & $\begin{array}{l}\text { G } \alpha_{q} \text { in } \\
\text { heterologous } \\
\text { cells }\end{array}$ & $\begin{array}{l}\text { Tharmalingam } \\
\text { et al., } 2012\end{array}$ & & \begin{tabular}{|l|} 
glutamate \\
$(8.61 \mu \mathrm{M})$, \\
quisqualate \\
$(169 \mu \mathrm{M})$, \\
DHPG (partial \\
agonist),
\end{tabular} & \\
\hline
\end{tabular}




\begin{tabular}{|l|l|l|l|l|l|l|}
\hline MGL-3 & $\begin{array}{l}\text { None-inferred } \\
\text { to be a } \\
\text { glutamate } \\
\text { receptor from } \\
\text { sequence } \\
\text { homology }\end{array}$ & & & & \\
\hline $\begin{array}{l}\text { Poorly-studied } \\
\text { putative } \\
\text { small-molecule } \\
\text { GPCRs }\end{array}$ & $\begin{array}{l}\text { Experimental } \\
\text { ligand } \\
\text { ligsignment }\end{array}$ & $\begin{array}{l}\text { G protein } \\
\text { coupling }\end{array}$ & $\begin{array}{l}\text { References G } \\
\text { protein } \\
\text { coupling }\end{array}$ & $\begin{array}{l}\text { References } \\
\text { binding } \\
\text { studies }\end{array}$ & $\begin{array}{l}\text { Agonists } \\
\text { (EC50) in } \\
\text { heterologous } \\
\text { cells }\end{array}$ & $\begin{array}{l}\text { References } \\
\text { heterologous } \\
\text { cell studies }\end{array}$ \\
\hline T02E9.3 & & & & & & \\
\hline C24A8.1 & & & & & & \\
\hline C24A8.6 & & & & & & \\
\hline F35H10.10 & & & & & & \\
\hline F59D12.1 & & & & & & \\
\hline T21B4.4 & & & & & \\
\hline
\end{tabular}

Table 2. Genetically-established functions and expression patterns of $C$. elegans $G$ protein coupled small molecule neurotransmitter receptors

\begin{tabular}{|c|c|c|c|c|}
\hline \begin{tabular}{|l|} 
Serotonin \\
receptors
\end{tabular} & $\begin{array}{l}\text { Functions revealed in } \\
\text { mutants }\end{array}$ & $\begin{array}{l}\text { References mutant } \\
\text { phenotype }\end{array}$ & Expression pattern & $\begin{array}{l}\text { References expression } \\
\text { pattern }\end{array}$ \\
\hline SER-1 & \begin{tabular}{|l|} 
Exogenous \\
serotonin-stimulated \\
egg laying, feeding, \\
and slowing of \\
locomotion, \\
$\alpha$-methyl-5-HT \\
stimulated egg laying, \\
male ventral tail \\
curling, food-induced \\
slowing, food \\
modulation of aversive \\
response, heat shock \\
response, longevity
\end{tabular} & $\begin{array}{l}\text { Carnell et al., 2005; } \\
\text { Dempsey et al., 2005; } \\
\text { Xiao et al., 2006; } \\
\text { Dernovici et al., 2007; } \\
\text { Murakami and } \\
\text { Murakami, 2007; } \\
\text { Srinivasan et al., 2008; } \\
\text { Harris et al., 2011 }\end{array}$ & $\begin{array}{l}\text { Pharyngeal muscle } \\
\text { (pm3, pm4, pm5, pm6, } \\
\text { pm7, pm8), CEP, } \\
\text { RMG, RMH, RMF, } \\
\text { RMD, RIA, RIC, } \\
\text { URY, additional head } \\
\text { neurons, vulval muscle } \\
\text { and epithelial cells, tail } \\
\text { neurons (PVT, PVQ, } \\
\text { possibly DVC) ventral } \\
\text { nerve cord, excretory } \\
\text { cell, uterine cells, ray } \\
\text { sensory neurons in } \\
\text { male }\end{array}$ & $\begin{array}{l}\text { Cho et al., 2000; Tsalik } \\
\text { et al., 2003; Carnell et } \\
\text { al., 2005; Dempsey et } \\
\text { al., 2005; Xiao et al., } \\
\text { 2006; Dernovici et al., } \\
\text { 2007 }\end{array}$ \\
\hline \begin{tabular}{|l|} 
SER-4 \\
\end{tabular} & $\begin{array}{l}\text { Egg laying induced by } \\
\text { imipramine but not by } \\
\text { fluoxetine or serotonin, } \\
\text { inhibition of } \\
\text { locomotion by } \\
\text { serotonin, effects of } \\
\text { ethanol on gustatory } \\
\text { plasticity and } \\
\text { locomotion, } \\
\text { thermotaxis memory } \\
\text { behavior }\end{array}$ & $\begin{array}{l}\text { Cho et al., 2000; } \\
\text { Dempsey et al., 2005; } \\
\text { Murakami and } \\
\text { Murakami, 2007; } \\
\text { Wang et al., 2011; } \\
\text { Gürel et al., 2012; Li et } \\
\text { al., } 2013\end{array}$ & $\begin{array}{l}\text { NSM, RIB or AIB, } \\
\text { RIS, pharyngeal } \\
\text { neuron, pair of } \\
\text { sublateral interneurons } \\
\text { or motorneurons, } \\
\text { retrovesicular ganglion, } \\
\text { PVT tail neuron, vm2 } \\
\text { vulval muscles, DVA } \\
\text { or DVC tail } \\
\text { interneuron }\end{array}$ & $\begin{array}{l}\text { Tsalik et al., 2003; } \\
\text { Gürel et al., 2012 }\end{array}$ \\
\hline
\end{tabular}




\begin{tabular}{|c|c|c|c|c|}
\hline SER-5 & $\begin{array}{l}\text { Exogenous } \\
\text { serotonin-stimulated } \\
\text { egg laying, food and } \\
\text { serotonin-dependent } \\
\text { increase in sensitivity } \\
\text { of ASH neurons to } \\
\text { octanol and decrease in } \\
\text { sensitivity to } \mathrm{Cu}^{2+} \text {. } \\
\text { Reduced sensitivity to } \\
\text { serotonin and } \\
\text { fluoxetine induced } \\
\text { paralysis. }\end{array}$ & $\begin{array}{l}\text { Hapiak et al., 2009; } \\
\text { Kullyev et al., 2010; } \\
\text { Harris et al., 2011; Guo } \\
\text { et al., } 2015\end{array}$ & $\begin{array}{l}\text { Neurons including } \\
\text { AWB and ASH, body } \\
\text { wall muscles, vulval } \\
\text { muscles }\end{array}$ & Hapiak et al., 2009 \\
\hline SER-7 & $\begin{array}{l}\text { Exogenous } \\
\text { serotonin-stimulated } \\
\text { egg laying, pharyngeal } \\
\text { pumping, and food } \\
\text { intake. Regulation of } \\
\text { pharyngeal pumping. } \\
\text { Egg laying. Hypoxia } \\
\text { regulation of gustatory } \\
\text { and effects of ethanol } \\
\text { on gustatory plasticity, } \\
\text { thermotaxis memory } \\
\text { behavior }\end{array}$ & $\begin{array}{l}\text { Hobson et al., 2006; } \\
\text { Donohoe et al., 2009; } \\
\text { Hapiak et al., 2009; } \\
\text { Pocock and Hobert, } \\
\text { 2010; Wang et al., } \\
\text { 2011; Song and Avery, } \\
\text { 2012; Song et al., } \\
\text { 2013; Li et al., 2013; } \\
\text { Gomez-Amaro et al., } \\
\text { 2015; Leiser et al., } \\
\text { 2015 }\end{array}$ & $\begin{array}{l}\text { Pharyngeal neurons } \\
\text { MC, M4, I2, I3, M5, } \\
\text { M3, I4, I6, and M2, } \\
\text { vulval muscles }\end{array}$ & Hobson et al., 2006 \\
\hline $\begin{array}{l}\text { Dopamine } \\
\text { receptors }\end{array}$ & $\begin{array}{l}\text { Functions revealed in } \\
\text { mutants }\end{array}$ & $\begin{array}{l}\text { References mutant } \\
\text { phenotype }\end{array}$ & Expression pattern & $\begin{array}{l}\text { References expression } \\
\text { pattern }\end{array}$ \\
\hline DOP-1 & $\begin{array}{l}\text { Antagonizes DOP-3 to } \\
\text { control locomotion, a } \\
\text { behavioral } \\
\text { decision-making } \\
\text { paradigm, and } \\
\text { acetylcholine release. } \\
\text { Regulates } \\
\text { swim-to-crawl } \\
\text { transition, fat } \\
\text { reservoirs, local food } \\
\text { search behavior. } \\
\text { Delays habituation to } \\
\text { mechanical } \\
\text { stimulation. Promotes } \\
\text { nicotine approach } \\
\text { behavior. }\end{array}$ & $\begin{array}{l}\text { Chase et al., 2004; } \\
\text { Sanyal et al., 2004; } \\
\text { Kindt et al., 2007; } \\
\text { Allen et al., 2011; } \\
\text { Vidal-Gadea et al., } \\
\text { 2011; Sellings et al., } \\
\text { 2013; Barros et al., } \\
\text { 2014; Bhattacharya et } \\
\text { al., 2014; Wang et al., } \\
\text { 2014 }\end{array}$ & $\begin{array}{l}\text { DVA, PLM, PHC, } \\
\text { ALN, ALM, AVM, } \\
\text { PLN, PVQ, AUA, RIB, } \\
\text { RIM, RIS, unidentified } \\
\text { head neurons, head } \\
\text { muscles, labial and } \\
\text { amphid sheath/socket } \\
\text { cells, excretory gland } \\
\text { cells, cholinergic } \\
\text { ventral cord motor } \\
\text { neurons }\end{array}$ & $\begin{array}{l}\text { Tsalik et al., 2003; } \\
\text { Sanyal et al., 2004; } \\
\text { Chase et al., 2004; } \\
\text { Bhattacharya et al., } \\
2014\end{array}$ \\
\hline
\end{tabular}




\begin{tabular}{|c|c|c|c|c|}
\hline DOP-2 & $\begin{array}{l}\text { Antagonizes } \\
\text { octopamine signaling, } \\
\text { inhibits CRE-mediated } \\
\text { gene expression in } \\
\text { SIA. Mediates } \\
\text { swimming-induced } \\
\text { paralysis. Inhibits } \\
\text { unproductive male } \\
\text { mating behavior. } \\
\text { Promotes nicotine } \\
\text { approach behavior. } \\
\text { Regulates touch } \\
\text { habituation and } \\
\text { chemosensory } \\
\text { associative learning. } \\
\text { Affects a } \\
\text { decision-making } \\
\text { paradigm. }\end{array}$ & $\begin{array}{l}\text { Suo et al., 2009; } \\
\text { Carvelli et al., 2010; } \\
\text { Correa et al., 2012; } \\
\text { Sellings et al., 2013; } \\
\text { Mersha et al. 2013; } \\
\text { Wang et al., 2014; } \\
\text { Correa et al., 2015 }\end{array}$ & $\begin{array}{l}\text { All dopaminergic } \\
\text { neurons of } \\
\text { hermaphrodite (CEP, } \\
\text { ADE, PDE) and } \\
\text { probably of male } \\
\text { (R5A, R7A, R9A). } \\
\text { RIA, SIA, SIB, RID, } \\
\text { PDA, HOA. }\end{array}$ & $\begin{array}{l}\text { Suo et al., 2003; Tsalik } \\
\text { et al., 2003; Suo et al., } \\
2009 \text {; Correa et al., } \\
2015\end{array}$ \\
\hline DOP-3 & $\begin{array}{l}\text { Antagonizes DOP-1 to } \\
\text { control locomotion, a } \\
\text { behavioral } \\
\text { decision-making } \\
\text { paradigm, and } \\
\text { acetylcholine release. } \\
\text { Mediates swimming } \\
\text { induced paralysis. } \\
\text { Inhibits unproductive } \\
\text { male mating behavior. } \\
\text { Antagonizes } \\
\text { octopamine signaling } \\
\text { and inhibits } \\
\text { CRE-mediated gene } \\
\text { expression in SIA. } \\
\text { Regulates avoidance of } \\
\text { octanol and } \\
\text { 2-nonanone. }\end{array}$ & $\begin{array}{l}\text { Chase et al., 2004; } \\
\text { McDonald et al., 2007; } \\
\text { Suo et al., 2009; Ezak } \\
\text { and Ferkey, 2010; } \\
\text { Carvelli et al., 2010; } \\
\text { Kimura et al., 2010; } \\
\text { Omura et al., 2012; } \\
\text { Correa et al., 2012; } \\
\text { Wang et al., 2014 }\end{array}$ & $\begin{array}{l}\text { Ventral cord } \\
\text { GABAergic and } \\
\text { cholinergic neurons, } \\
\text { ASK, PVD, SIA, RIC, } \\
\text { head neurons, tail } \\
\text { neurons, body wall } \\
\text { muscles, male tail cells }\end{array}$ & $\begin{array}{l}\text { Chase et al., 2004; Suo } \\
\text { et al., 2009; Ezak and } \\
\text { Ferkey, 2010; Correa et } \\
\text { al., 2012; }\end{array}$ \\
\hline DOP-4 & $\begin{array}{l}\text { Mediates swimming } \\
\text { induced paralysis, } \\
\text { swim/crawl transition, } \\
\text { food enhancement of } \\
\text { ASH response to } \\
\text { repellents, } \\
\text { alcohol-induced } \\
\text { disinhibition of } \\
\text { crawling. }\end{array}$ & $\begin{array}{l}\text { Carvelli et al., 2010; } \\
\text { Ezcurra et al., 2011; } \\
\text { Topper et al., 2014; } \\
\text { Vidal-Gadea et al., } \\
2011\end{array}$ & $\begin{array}{l}\text { I1, I2, ASG, AVL, } \\
\text { CAN, PQR, vulva, } \\
\text { intestine, rectal glands, } \\
\text { rectal epithelial cells, } \\
\text { male ray 8, additional } \\
\text { head neurons, ASH } \\
\text { (inferred indirectly). }\end{array}$ & $\begin{array}{l}\text { Sugiura et al., 2005; } \\
\text { Ezcurra et al., 2011 }\end{array}$ \\
\hline $\begin{array}{l}\begin{array}{l}\text { Octopamine } \\
\text { receptors }\end{array} \\
\end{array}$ & $\begin{array}{l}\text { Functions revealed in } \\
\text { mutants }\end{array}$ & $\begin{array}{l}\text { References mutant } \\
\text { phenotype }\end{array}$ & Expression pattern & $\begin{array}{l}\text { References expression } \\
\text { pattern }\end{array}$ \\
\hline \begin{tabular}{|l|} 
OCTR-1 \\
\end{tabular} & $\begin{array}{l}\text { Mediates effect of } \\
\text { exogenous octopamine } \\
\text { on response to octanol. } \\
\text { Controls innate } \\
\text { immunity by regulating } \\
\text { the unfolded protein } \\
\text { response. }\end{array}$ & $\begin{array}{l}\text { Wragg et al., 2007; } \\
\text { Harris et al., 2010; Sun } \\
\text { et al., 2011; Mills et } \\
\text { al., 2012; Sun et al., } \\
2012\end{array}$ & $\begin{array}{l}\text { ASI, ASH, AIY, ADE, } \\
\text { CEP, spermatheca, } \\
\text { uterine toroid cells, } \\
\text { head and tail neurons }\end{array}$ & Wragg et al., 2007 \\
\hline
\end{tabular}




\begin{tabular}{|c|c|c|c|c|}
\hline SER-3 & $\begin{array}{l}\text { Mediates octopamine- } \\
\text { and starvation-induced } \\
\text { expression of a } \\
\text { CREB-dependent } \\
\text { reporter gene in SIA } \\
\text { neurons. Antagonizes } \\
\text { OCTR-1 in the control } \\
\text { of octanol response by } \\
\text { exogenous octopamine. } \\
\text { Mediates inhibition of } \\
\text { ASI sensory neuron by } \\
\text { ASH sensory neuron } \\
\text { via a circuit involving } \\
\text { octopamine released } \\
\text { from RIC. }\end{array}$ & $\begin{array}{l}\text { Suo et al., 2006; Mills } \\
\text { et al., 2012; Guo et al., } \\
2015\end{array}$ & $\begin{array}{l}\text { ASH, ASG, ASI, SIA, } \\
\text { PHA, PHB, PVQ, } \\
\text { neurons in the head and } \\
\text { tail, head muscles, } \\
\text { intestine, phasmid } \\
\text { socket cells, } \\
\text { spermatheca }\end{array}$ & $\begin{array}{l}\text { Suo et al., 2006; Mills } \\
\text { et al., 2012; Guo et al., } \\
2015\end{array}$ \\
\hline SER-6 & $\begin{array}{l}\text { Mediates octopamine- } \\
\text { and starvation-induced } \\
\text { expression of a } \\
\text { CREB-dependent } \\
\text { reporter gene in SIA } \\
\text { neurons. Mediates } \\
\text { exogenous } \\
\text { serotonin-stimulated } \\
\text { fat reduction. Mediates } \\
\text { exogenous octopamine } \\
\text { mediated inhibition of } \\
\text { response to } 100 \% \\
\text { octanol. }\end{array}$ & $\begin{array}{l}\text { Srinivasan et al., 2008; } \\
\text { Mills et al., 2012; } \\
\text { Yoshida et al., 2014 }\end{array}$ & $\begin{array}{l}\text { SIA, RIC, AWB, ADL, } \\
\text { ASI, head neurons, tail } \\
\text { neurons, posterior } \\
\text { ventral cord neurons, } \\
\text { intestine }\end{array}$ & $\begin{array}{l}\text { Srinivasan et al., 2008; } \\
\text { Yoshida et al., } 2014\end{array}$ \\
\hline $\begin{array}{l}\text { Tyramine } \\
\text { receptors }\end{array}$ & $\begin{array}{l}\text { Functions revealed in } \\
\text { mutants }\end{array}$ & $\begin{array}{l}\text { References mutant } \\
\text { phenotype }\end{array}$ & Expression pattern & $\begin{array}{l}\text { References expression } \\
\text { pattern }\end{array}$ \\
\hline SER-2 & $\begin{array}{l}\text { Mediates paralysis and } \\
\text { suppression of } \\
\text { pharyngeal pumping by } \\
\text { exogenous tyramine. } \\
\text { Suppresses head } \\
\text { movements during } \\
\text { backing. Facilitates } \\
\text { execution of omega } \\
\text { turns. }\end{array}$ & \begin{tabular}{|l|} 
Rex et al., 2004; \\
Donelly et al., 2013
\end{tabular} & $\begin{array}{l}\text { Neurons: AIY, AVH, } \\
\text { AUA, RIC, SAB, RID, } \\
\text { RIA, SDQ, CAN, } \\
\text { DA9, LUA, ALN, } \\
\text { PVC, NSM, AIZ, } \\
\text { DVA, BDU, SIA, } \\
\text { RME, PVT, OLL, } \\
\text { PVD, VD. Excretory } \\
\text { gland cells. Muscles: } \\
\text { pm1, pm6, head } \\
\text { muscles, male posterior } \\
\text { body wall muscles and } \\
\text { diagonal muscles. } \\
\text { Possibly male CP } \\
\text { neurons. Uterine toroid } \\
\text { cells ut1 and ut2. }\end{array}$ & $\begin{array}{l}\text { Tsalik et al., 2003; Rex } \\
\text { et al., 2004; Donelly et } \\
\text { al., 2013 }\end{array}$ \\
\hline TYRA-2 & & & $\begin{array}{l}\text { MCL, NSM, ASE, } \\
\text { ASG, ASH, ASI, PVD, } \\
\text { CAN, ALM }\end{array}$ & Rex et al., 2005 \\
\hline
\end{tabular}




\begin{tabular}{|c|c|c|c|c|}
\hline TYRA-3 & $\begin{array}{l}\text { Mediates effect of } \\
\text { exogenous tyramine on } \\
\text { response to octanol; } \\
\text { affects decision to } \\
\text { leave bacterial lawn. } \\
\text { Antagonizes the effect } \\
\text { of serotonin to } \\
\text { sensitize aversive } \\
\text { responses. }\end{array}$ & $\begin{array}{l}\text { Wragg et al., 2007; } \\
\text { Bendesky et al., 2011; } \\
\text { Hapiak et a., 2013; }\end{array}$ & $\begin{array}{l}\text { ADE, CEP, ASK, } \\
\text { ADL, AIM, AUA, } \\
\text { BAG, DEP, OLQ, } \\
\text { SDQL, AFD, AWC, } \\
\text { RIC, ASI, } \\
\text { spermatheca, distal tip } \\
\text { cell, vulval muscles, } \\
\text { additional head and tail } \\
\text { neurons }\end{array}$ & $\begin{array}{l}\text { Carre-Pierrat et al., } \\
\text { 2006; Unpublished } \\
\text { results cited in Wragg } \\
\text { et al., 2007; Bendesky } \\
\text { et al., 2011 }\end{array}$ \\
\hline $\begin{array}{l}\text { Acetylcholine } \\
\text { receptors }\end{array}$ & $\begin{array}{l}\text { Functions revealed in } \\
\text { mutants }\end{array}$ & $\begin{array}{l}\text { References mutant } \\
\text { phenotype }\end{array}$ & Expression pattern & $\begin{array}{l}\text { References expression } \\
\text { pattern }\end{array}$ \\
\hline GAR-1 & & & head neurons, PVM & Lee et al., 2000 \\
\hline GAR-2 & $\begin{array}{l}\text { Mediates inhibition of } \\
\text { egg laying. Mediates } \\
\text { feedback inhibition of } \\
\text { cholinergic ventral } \\
\text { cord motor neurons to } \\
\text { regulate locomotion. }\end{array}$ & $\begin{array}{l}\text { Bany et al., 2003; } \\
\text { Dittman and Kaplan, } \\
2008\end{array}$ & $\begin{array}{l}\text { head neurons, ventral } \\
\text { cord GABAergic and } \\
\text { cholinergic, neurons, } \\
\text { cell near vulva }\end{array}$ & $\begin{array}{l}\text { Lee et al., 2000; } \\
\text { Dittman and Kaplan, } \\
2008\end{array}$ \\
\hline GAR-3 & $\begin{array}{l}\text { Regulates multiple } \\
\text { calcium-dependent } \\
\text { processes in } \\
\text { pharyngeal muscle. } \\
\text { Sensitizes nicotinic } \\
\text { signaling in male } \\
\text { spicule neurons and } \\
\text { muscles to facilitate } \\
\text { mating. Regulates head } \\
\text { movements by } \\
\text { compartmentalizing } \\
\text { axon activity in the } \\
\text { RIA interneuron. } \\
\text { Promotes acetylcholine } \\
\text { release from } \\
\text { cholinergic motor } \\
\text { neurons. }\end{array}$ & $\begin{array}{l}\text { Steger and Avery, } \\
\text { 2004; Liu et al., 2007; } \\
\text { Hendricks et al., 2012; } \\
\text { Chan J.P. et al., 2013 }\end{array}$ & $\begin{array}{l}\text { I3, pharyngeal muscle, } \\
\text { body wall muscles, } \\
\text { anal depressor muscle, } \\
\text { cholinergic ventral } \\
\text { cord neurons, VD, DD, } \\
\text { male diagonal muscles, } \\
\text { male ray } 8 \text { neuron, } \\
\text { SPC, PCB, and PCA } \\
\text { neurons and the spicule } \\
\text { protractor muscles }\end{array}$ & \begin{tabular}{|l} 
Steger and Avery, \\
2004; Liu et al., 2007; \\
Chan J.P. et al., 2013
\end{tabular} \\
\hline $\begin{array}{l}\text { GABA } \\
\text { receptors }\end{array}$ & $\begin{array}{l}\text { Functions revealed in } \\
\text { mutants }\end{array}$ & $\begin{array}{l}\text { References mutant } \\
\text { phenotype }\end{array}$ & Expression pattern & $\begin{array}{l}\text { References expression } \\
\text { pattern }\end{array}$ \\
\hline GBB-1 & $\begin{array}{l}\text { With GBB-2, decreases } \\
\text { acetylcholine release } \\
\text { from ventral cord } \\
\text { motor neurons to } \\
\text { regulate locomotion. } \\
\text { Affects lifespan. }\end{array}$ & $\begin{array}{l}\text { Dittman and Kaplan, } \\
\text { 2008; Schultheis et al., } \\
\text { 2011; Chun et al., } 2015\end{array}$ & $\begin{array}{l}\text { Expression in ventral } \\
\text { cord cholinergic } \\
\text { neurons in inferred } \\
\text { indirectly. }\end{array}$ & $\begin{array}{l}\text { Dittman and Kaplan, } \\
\text { 2008; Schultheis et al., } \\
\text { 2011 }\end{array}$ \\
\hline GBB-2 & $\begin{array}{l}\text { With GBB-1, decreases } \\
\text { acetylcholine release } \\
\text { from ventral cord } \\
\text { motor neurons to } \\
\text { regulate locomotion. }\end{array}$ & $\begin{array}{l}\text { Dittman and Kaplan } \\
\text { 2008; Schultheis et al., } \\
\text { 2011 }\end{array}$ & $\begin{array}{l}\text { Expression in ventral } \\
\text { cord cholinergic } \\
\text { neurons in inferred } \\
\text { indirectly. }\end{array}$ & $\begin{array}{l}\text { Dittman and Kaplan } \\
\text { 2008; Schultheis et al., } \\
\text { 2011 }\end{array}$ \\
\hline
\end{tabular}




\begin{tabular}{|c|c|c|c|c|}
\hline $\begin{array}{l}\text { Glutamate } \\
\text { receptor } \\
\text { homologs }\end{array}$ & \begin{tabular}{|l|} 
Functions revealed in \\
mutants
\end{tabular} & $\begin{array}{l}\text { References mutant } \\
\text { phenotype }\end{array}$ & Expression pattern & $\begin{array}{l}\text { References expression } \\
\text { pattern }\end{array}$ \\
\hline MGL-1 & \begin{tabular}{|l|} 
Regulates starvation \\
response, perhaps by \\
directly sensing amino \\
acids from food. \\
Pharmacological \\
activation of MGL-1 \\
inhibits pharyngeal \\
pumping. Mediates \\
reduction in pharyngeal \\
pumping when animals \\
are removed from food.
\end{tabular} & $\begin{array}{l}\text { Kang and Avery, 2009; } \\
\text { Dillon et al,. } 2015\end{array}$ & $\begin{array}{l}\text { Expression in AIY and } \\
\text { AIB is inferred } \\
\text { indirectly. Head } \\
\text { neurons, tail neurons, } \\
\text { pharyngeal neurons } \\
\text { including NSM. }\end{array}$ & $\begin{array}{l}\text { Kang and Avery, 2009; } \\
\text { Dillon et al,. } 2015\end{array}$ \\
\hline MGL-2 & \begin{tabular}{|l|} 
Regulates starvation \\
response, perhaps by \\
directly sensing amino \\
acids from food.
\end{tabular} & Kang and Avery, 2009 & $\begin{array}{l}\text { Expression in AIY and } \\
\text { AIB is inferred } \\
\text { indirectly. Head } \\
\text { neurons, tail neurons, } \\
\text { pharyngeal neurons } \\
\text { including NSM, I5, } \\
\text { intestine, } \\
\text { pharyngeal-intestinal } \\
\text { valve, pharyngeal } \\
\text { muscle. }\end{array}$ & $\begin{array}{l}\text { Kang and Avery, 2009; } \\
\text { Dillon et al,. } 2015\end{array}$ \\
\hline MGL-3 & & & $\begin{array}{l}\text { Head neurons, } \\
\text { pharyngeal neurons } \\
\text { including NSM. }\end{array}$ & Dillon et al., 2015 \\
\hline
\end{tabular}

\section{References}

Abbott, N.J., Williamson, R., and Maddock, L. (1995). Cephalopod neurobiology: neuroscience studies in squid, octopus and cuttlefish. (Oxford: Oxford University Press). Abstract

Agnati, L.F., Fuxe, K., Zoli, M., Ozini, I., Toffano, G., and Ferraguti, F. (1986). A correlation analysis of the regional distribution of central enkephalin and $\beta$-endorphin immunoreactive terminals and of opiate receptors in adult and old male rats. Evidence for the existence of two main types of communication in the central nervous system: the volume transmission and the wiring transmission. Acta Physiol. Scand. 128, 201-207. Abstract Article

Agnati, L.F., Guidolin, D., Guescini, M., Genedani, S., and Fuxe, K. (2010). Understanding wiring and volume transmission. Brain Res. Rev. 64, 137-159. Abstract Article

Allen, A.T., Maher, K.N., Wani, K.A., Betts, K.E., and Chase, D.L. (2011). Coexpressed D1- and D2-like dopamine receptors antagonistically modulate acetylcholine release in Caenorhabditis elegans. Genetics 188, 579-590. Abstract Article

Altun, Z.F. (2011). Neurotransmitter receptors in C. elegans. In WormAtlas. doi:10.3908/wormatlas.5.202 Article

Anderson, G.R., Posokhova, E., and Martemyanov, K.A. (2009). The R7 RGS protein family: multi-subunit regulators of neuronal $\mathrm{G}$ protein signaling. Cell Biochem. Biophys. 54, 33-46. Abstract Article

Bailey, C.H., and Kandel ER. (2008). Synaptic remodeling, synaptic growth and the storage of long-term memory in Aplysia. Prog. Brain Res. 169, 179-198. Abstract Article

Bany, I.A., Dong, M.Q., and Koelle, M.R. (2003). Genetic and cellular basis for acetylcholine inhibition of Caenorhabditis elegans egg-laying behavior. J. Neurosci. 23, 8060-8069. Abstract Article 
Barberis, A., Petrini, E.M., and Mozrzymas, J.W. (2011). Impact of synaptic neurotransmitter concentration time course on the kinetics and pharmacological modulation of inhibitory synaptic currents. Front. Cell. Neurosci. 5, 6. Abstract Article

Barros, A.G., Bridi, J.C., de Souza, B.R., de Castro Júnior, C., de Lima Torres, K.C., Malard, L., Jorio, A., de Miranda, D.M., Ashrafi, K., and Romano-Silva, M.A. (2014). Dopamine signaling regulates fat content through $\beta$-oxidation in Caenorhabditis elegans. PLoS One 9, e85874. Abstract Article

Bastiani, C.A., Gharib, S., Simon, M.I., and Sternberg, P.W. (2003). Caenorhabditis elegans G $\alpha_{q}$ regulates egg-laying behavior via a PLC $\beta$-independent and serotonin-dependent signaling pathway and likely functions both in the nervous system and in muscle. Genetics $165,1805-1822$.

Bastiani, C. and Mendel, J. Heterotrimeric G proteins in C. elegans (October 13, 2006), WormBook, ed. The C. elegans Research Community, WormBook, doi/10.1895/wormbook.1.75.1, http://www.wormbook.org. Abstract Article

Beaulieu, J.M., and Gainetdinov, R.R. (2011). The physiology, signaling, and pharmacology of dopamine receptors. Pharmacol. Rev. 63, 182-217. Abstract Article

Belfer, S.J,, Chuang, H.S., Freedman, B.L., Yuan, J., Norton, M., Bau, H.H., and Raizen, D,M. (2013). Caenorhabditis-in-drop array for monitoring C. elegans quiescent behavior. Sleep 36, 689-698G. Abstract Article

Bendesky, A., Tsunozaki, M., Rockman, M.V., Kruglyak, L., and Bargmann, C.I. (2011). Catecholamine receptor polymorphisms affect decision-making in C. elegans. Nature 472, 313-318. Abstract Article

Berger, A.J., Hart, A.C., and Kaplan, J.M. (1998). G $\alpha_{s}$-induced neurodegeneration in Caenorhabditis elegans. J. Neurosci. 18, 2871-2880. Abstract Article

Berman, D.M., Kozasa, T., and Gilman, A.G. (1996). The GTPase-activating protein RGS4 stabilizes the transition state for nucleotide hydrolysis. J. Biol. Chem. 271, 27209-27212. Abstract Article

Bhattacharya, R., Touroutine, D., Barbagallo, B., Climer, J., Lambert, C.M., Clark, C.M., Alkema, M.J., and Francis, M.M. (2014). A conserved dopamine-cholecystokinin signaling pathway shapes context-dependent Caenorhabditis elegans behavior. PLoS Genet. 10, e1004584. Abstract Article

Brandt, D.R., and Ross, E.M. (1986). Catecholamine-stimulated GTPase cycle. Multiple sites of regulation by $\beta$-adrenergic receptor and $\mathrm{Mg}^{2+}$ studied in reconstituted receptor-Gs vesicles. J. Biol. Chem. 261, 1656-1664. Abstract Article

Brenner, S. (1974). The genetics of Caenorhabditis elegans. Genetics 77, 71-94. Abstract Article

Brundage, L., Avery, L., Katz, A., Kim, U.J., Mendel, J.E., Sternberg, P.W., and Simon, M.I. (1996). Mutations in a C. elegans $\mathrm{G}_{\mathrm{q}} \alpha$ gene disrupt movement, egg laying, and viability. Neuron 6, 999-1009. Abstract Article

C. elegans Deletion Mutant Consortium. (2012). Large-scale screening for targeted knockouts in the Caenorhabditis elegans genome. G3 2, 1415-1425. Abstract Article

Carnell, L., Illi, J., Hong, S.W., and McIntire, S.L. (2005). The G-protein-coupled serotonin receptor SER-1 regulates egg laying and male mating behaviors in Caenorhabditis elegans. J. Neurosci. 25, 10671-1081. Abstract Article

Carre-Pierrat, M., Baillie, D., Johnsen, R., Hyde, R., Hart, A., Granger, L., and Ségalat, L. (2006). Characterization of the Caenorhabditis elegans $\mathrm{G}$ protein-coupled serotonin receptors. Invert. Neurosci. 6, 189-205. Abstract Article

Carvelli, L., Matthies, D.S., and Galli, A. (2010). Molecular mechanisms of amphetamine actions in Caenorhabditis elegans. Mol. Pharmacol. 78, 151-156. Abstract Article

Chan, J.P., Hu, Z., and Sieburth, D. (2012). Recruitment of sphingosine kinase to presynaptic terminals by a conserved muscarinic signaling pathway promotes neurotransmitter release. Genes Dev. 26, 1070-1085. Abstract Article 
Chan, J.P., Staab, T.A., Wang, H., Mazzasette, C., Butte, Z., and Sieburth, D. (2013). Extrasynaptic muscarinic acetylcholine receptors on neuronal cell bodies regulate presynaptic function in Caenorhabditis elegans. J. Neurosci. 33, 14146-14159. Abstract Article

Chan, P., Gabay, M., Wright, F.A., and Tall, G.G. (2011). Ric-8B is a GTP-dependent G protein $\alpha_{\mathrm{s}}$ guanine nucleotide exchange factor. J. Biol. Chem. 286, 19932-19942. Abstract Article

Chan, P., Thomas, C.J., Sprang, S.R., and Tall, G.G. (2013). Molecular chaperoning function of Ric-8 is to fold nascent heterotrimeric G protein $\alpha$ subunits. Proc. Natl. Acad. Sci. U. S. A. 110, 3794-3799. Abstract Article

Charlie, N.K., Schade, M.A., Thomure, A.M., and Miller, K.G. (2006a). Presynaptic UNC-31 (CAPS) is required to activate the $\mathrm{G} \alpha_{\text {s }}$ pathway of the Caenorhabditis elegans synaptic signaling network. Genetics 172, 943-961. Abstract Article

Charlie, N.K., Thomure, A.M., Schade, M.A., and Miller, K.G. (2006b). The Dunce cAMP phosphodiesterase PDE-4 negatively regulates $\mathrm{G} \alpha_{\mathrm{s}}$-dependent and $\mathrm{G} \alpha_{\mathrm{s}}$-independent cAMP pools in the Caenorhabditis elegans synaptic signaling network. Genetics 173, 111-130. Abstract Article

Chase, D.L. and Koelle, M.R. (2004). Genetic analysis of RGS protein function in Caenorhabditis elegans. Methods Enzymol. 389, 305-320. Abstract Article

Chase, D.L. and Koelle, M.R. Biogenic amine neurotransmitters in C. elegans (February 20, 2007), WormBook, ed. The C. elegans Research Community, WormBook, doi/10.1895/wormbook.1.132.1, http://www.wormbook.org. Abstract Article

Chase, D.L., Patikoglou, G.A., and Koelle, M.R. (2001). Two RGS proteins that inhibit $\mathrm{G}_{\mathrm{o}}$ and $\mathrm{G}_{\mathrm{q}}$ signaling in $C$. elegans neurons require a $\mathrm{G} \beta_{5}$-like subunit for function. Curr. Biol. 11, 222-231. Abstract Article

Chase, D.L., Pepper, J.S., and Koelle, M.R. (2004). Mechanism of extrasynaptic dopamine signaling in Caenorhabditis elegans. Nat. Neurosci. 7, 1096-1103. Abstract Article

Chen, C., and Regehr, W.G. (1997). The mechanism of cAMP-mediated enhancement at a cerebellar synapse. J. Neurosci. 17, 8687-8694. Abstract Article

Chen, L.T., Gilman, A.G., and Kozasa. T. (1999). A candidate target for G protein action in brain. J. Biol. Chem. 274, 26931-26938. Abstract Article

Cheong, M.C., Artyukhin, A.B., You, Y.J., and Avery, L. (2015). An opioid-like system regulating feeding behavior in C. elegans. eLife 4, doi: 10.7554/eLife.06683. Abstract Article

Cho, J.H., Bandyopadhyay, J., Lee, J., Park, C.S., and Ahnn, J. (2000). Two isoforms of sarco/endoplasmic reticulum calcium ATPase (SERCA) are essential in Caenorhabditis elegans. Gene 261, 211-219. Abstract Article

Choi, S., Chatzigeorgiou, M., Taylor, K.P., Schafer, W.R., and Kaplan, J.M. (2013). Analysis of NPR-1 reveals a circuit mechanism for behavioral quiescence in C. elegans. Neuron 78, 869-880. Abstract Article

Chun, L., Gong, J., Yuan, F., Zhang, B., Liu, H., Zheng, T., Yu, T., Xu, X.Z., and Liu, J. (2015). Metabotropic GABA signalling modulates longevity in C. elegans. Nat. Commun. 6, 8828. Abstract Article

Coates, J.C., and de Bono, M. (2002). Antagonistic pathways in neurons exposed to body fluid regulate social feeding in Caenorhabditis elegans. Nature 419, 925-929. Abstract Article

Cohen, M., Reale, V., Olofsson, B., Knights, A., Evans, P., and de Bono, M. (2009). Coordinated regulation of foraging and metabolism in C. elegans by RFamide neuropeptide signaling. Cell Metab. 9, 375-385. Abstract Article

Cole, G.M., Stone, D.E., and Reed, S.I. (1990). Stoichiometry of G protein subunits affects the Saccharomyces cerevisiae mating pheromone signal transduction pathway. Mol. Cell. Biol. 10, 510-517. Abstract Article

Coleman, D.E., Berghuis, A.M., Lee, E., Linder, M.E., Gilman, A.G., and Sprang, S.R. (1994). Structures of active conformations of Gial and the mechanism of GTP hydrolysis. Science 265, 1405-1412. Abstract Article 
Collins, K.M., and Koelle, M.R. (2013). Postsynaptic ERG potassium channels limit muscle excitability to allow distinct egg-laying behavior states in Caenorhabditis elegans. J. Neurosci. 33, 761-775. Abstract Article

Colombo, K., Grill, S.W., Kimple, R.J., Willard, F.S., Siderovski, D.P., and Gönczy, P. (2003). Translation of polarity cues into asymmetric spindle positioning in Caenorhabditis elegans embryos. Science 300, 1957-1961. Abstract Article

Conn, P.J., and Roth, B.L. (2008). Opportunities and challenges of psychiatric drug discovery: roles for scientists in academic, industry, and government settings. Neuropsychopharmacology 33, 2048-2060. Abstract Article

Cori, C.F., and Cori, G.T. (1947). Polysaccharide Phosphorylase. In Nobel Lectures-Physiology or Medicine 1942-1962. (Amsterdam: Elsevier Publishing Company), pp. 186-206. Abstract Article

Correa, P.A., Gruninger, T., and García, L.R. (2015). DOP-2 D2-like receptor regulates UNC-7 innexins to attenuate recurrent sensory motor neurons during C. elegans copulation. J. Neurosci. 35, 9990-10004. Abstract Article

Correa, P., LeBoeuf, B., and García, L.R. (2012). C. elegans dopaminergic D2-like receptors delimit recurrent cholinergic-mediated motor programs during a goal-oriented behavior. PLoS Genet. 8, e1003015. Abstract Article

Cuppen, E., van der Linden, A.M., Jansen, G., and Plasterk, R.H. (2003). Proteins interacting with Caenorhabditis elegans $\mathrm{G} \alpha$ subunits. Comp. Funct. Genomics 4, 479-491. Abstract Article

de Bono, M., and Bargmann, C.I. (1998). Natural variation in a neuropeptide Y receptor homolog modifies social behavior and food response in C. elegans. Cell 94, 679-689. Abstract Article

Dempsey, C.M., Mackenzie, S.M., Gargus, A., Blanco, G., Sze, J.Y. (2005). Serotonin (5HT), fluoxetine, imipramine and dopamine target distinct $5 \mathrm{HT}$ receptor signaling to modulate Caenorhabditis elegans egg-laying behavior. Genetics 169, 1425-1436. Abstract Article

Dernovici, S., Starc, T., Dent, J.A., and Ribeiro, P. (2007). The serotonin receptor SER-1 (5HT2ce) contributes to the regulation of locomotion in Caenorhabditis elegans. Dev. Neurobiol. 67, 189-204. Abstract Article

Desai, C., and Horvitz, H.R. (1989). Caenorhabditis elegans mutants defective in the functioning of the motor neurons responsible for egg laying. Genetics 121, 703-721. Abstract Article

Dietzel, C., and Kurjan, J. (1987). Pheromonal regulation and sequence of the Saccharomyces cerevisiae SST2 gene: a model for desensitization to pheromone. Mol. Cell Biol. 7, 4169-4177. Abstract Article

Dillon, J., Franks, C.J., Murray, C., Edwards, R.J., Calahorro, F., Ishihara, T., Katsura, I., Holden-Dye, L., and O'Connor, V. (2015). Metabotropic glutamate receptors: modulators of context-dependent feeding behavior in $C$. elegans. J. Biol. Chem. 290, 15052-15065. Abstract Article

Dittman, J.S., and Kaplan, J.M. (2008). Behavioral impact of neurotransmitter-activated G-protein-coupled receptors: muscarinic and $\mathrm{GABAB}$ receptors regulate Caenorhabditis elegans locomotion. J. Neurosci. 28, 7104-7112. Abstract Article

Dohlman, H.G., and Thorner, J.W. (2001). Regulation of G protein-initiated signal transduction in yeast: paradigms and principles. Annu. Rev. Biochem. 70, 703-754. Abstract Article

Dohlman, H.G., Song, J., Ma, D., Courchesne, W.E., Thorner, J. (1996). Sst2, a negative regulator of pheromone signaling in the yeast Saccharomyces cerevisiae: expression, localization, and genetic interaction and physical association with Gpa1 (the G-protein $\alpha$ subunit). Mol. Cell Biol. 16, 5194-5209. Abstract Article

Donaldson, Z.R., Nautiyal, K.M., Ahmari, S.E., and Hen. R. (2013). Genetic approaches for understanding the role of serotonin receptors in mood and behavior. Curr. Opin. Neurobiol. 23, 399-406. Abstract Article

Dong, M.Q., Chase, D., Patikoglou, G.A., and Koelle, M.R. (2000). Multiple RGS proteins alter neural G protein signaling to allow C. elegans to rapidly change behavior when fed. Genes Dev. 14, 2003-2014. Abstract Article 
Donnelly, J.L., Clark, C.M., Leifer, A.M., Pirri, J.K., Haburcak, M., Francis, M.M., Samuel, A.D., and Alkema, M.J. (2013). Monoaminergic orchestration of motor programs in a complex C. elegans behavior. PLoS Biol. 11, e1001529. Abstract Article

Donohoe, D.R., Jarvis, R.A., Weeks, K., Aamodt, E.J., and Dwyer, D.S. (2009). Behavioral adaptation in C. elegans produced by antipsychotic drugs requires serotonin and is associated with calcium signaling and calcineurin inhibition. Neurosci. Res. 64, 280-289. Abstract Article

Emtage, L., Aziz-Zaman, S., Padovan-Merhar, O., Horvitz, H.R., Fang-Yen, C., and Ringstad, N. (2012). IRK-1 potassium channels mediate peptidergic inhibition of Caenorhabditis elegans serotonin neurons via a Go signaling pathway. J. Neurosci. 32, 16285-16295. Abstract Article

Ezak, M.J., and Ferkey, D.M. (2010). The C. elegans D2-like dopamine receptor DOP-3 decreases behavioral sensitivity to the olfactory stimulus 1-octanol. PLoS One 5, e9487. Abstract Article

Ezcurra, M., Tanizawa, Y., Swoboda, P., and Schafer, W.R. (2011). Food sensitizes C. elegans avoidance behaviours through acute dopamine signalling. EMBO J. 30, 1110-1122. Abstract Article

Fantegrossi, W.E., Murnane, K.S., and Reissig, C.J. (2008). The behavioral pharmacology of hallucinogens. Biochem. Pharmacol. 75, 17-33. Abstract Article

Ferkey, D.M., Hyde, R., Haspel, G., Dionne, H.M., Hess, H.A., Suzuki, H., Schafer, W.R., Koelle, M.R., and Hart, A.C. (2007). C. elegans G protein regulator RGS-3 controls sensitivity to sensory stimuli. Neuron 53, 39-52. Abstract Article

Fischer, E.H. (1992). Protein Phosphorylation and Cellular Regulation, II. In Nobel Lectures, Physiology or Medicine 1991-1995. N. Ringertz, ed. (Singapore: World Scientific Publishing Co.), pp. 95-113. Article

Frooninckx, L., Van Rompay, L., Temmerman, L., Van Sinay, E., Beets, I., Janssen, T.,Husson, S.J., and Schoofs, L. (2012). Neuropeptide GPCRs in C. elegans. Front. Endocrinol. 3, 167. Abstract Article

Fukuto, H.S., Ferkey, D.M., Apicella, A.J., Lans, H., Sharmeen, T., Chen, W., Lefkowitz, R.J., Jansen, G., Schafer, W.R., and Hart, A.C. (2004). G protein-coupled receptor kinase function is essential for chemosensation in $C$. elegans. Neuron 42, 581-593. Abstract Article

Fung, B.K., Hurley, J.B., and Stryer, L. (1981). Flow of information in the light-triggered cyclic nucleotide cascade of vision. Proc. Natl. Acad. Sci. U. S. A. 78, 152-156. Abstract Article

Gabay, M., Pinter, M.E., Wright, F.A., Chan, P., Murphy, A.J., Valenzuela, D.M., Yancopoulos, G.D., and Tall, G.G. (2011). Ric-8 proteins are molecular chaperones that direct nascent $\mathrm{G}$ protein $\alpha$ subunit membrane association. Sci. Signal. 4, ra79. Abstract Article

Ghosh-Roy, A., Wu, Z., Goncharov, A., Jin, Y., and Chisholm, A.D. (2010). Calcium and cyclic AMP promote axonal regeneration in Caenorhabditis elegans and require DLK-1 kinase. J. Neurosci. 30, 3175-3183. Abstract Article

Gilman, A.G. (1994). G Proteins and Regulation of Adenylyl Cyclase. In Nobel Lectures - Physiology or Medicine 1991-1995. N. Ringertz, ed. (Singapore: World Scientific Publishing Co.), pp. 182-212. Article

Godinho, R.O., Duarte, T., and Pacini, E.S. (2015). New perspectives in signaling mediated by receptors coupled to stimulatory G protein: the emerging significance of cAMP efflux and extracellular cAMP-adenosine pathway. Front. Pharmacol. 6, 58. Abstract Article

Gomez-Amaro, R.L., Valentine, E.R., Carretero, M., LeBoeuf, S.E., Rangaraju, S., Broaddus, C.D., Solis, G.M., Williamson, J.R., and Petrascheck, M. (2015). Measuring food intake and nutrient absorption in Caenorhabditis elegans. Genetics 200, 443-454. Abstract Article

González-Maeso, J. (2011). GPCR oligomers in pharmacology and signaling. Mol. Brain 4, 20. Abstract Article

Gotta, M., and Ahringer J. (2001). Distinct roles for G $\alpha$ and $G \beta \gamma$ in regulating spindle position and orientation in Caenorhabditis elegans embryos. Nat. Cell Biol. 3, 297-300. Abstract Article 
Gotta, M., Dong, Y., Peterson, Y.K., Lanier, S.M., and Ahringer, J. (2003). Asymmetrically distributed C. elegans homologs of AGS3/PINS control spindle position in the early embryo. Curr. Biol. 13, 1029-1037. Abstract Article

Govindan, J.A., Cheng, H., Harris, J.E., and Greenstein, D. (2006). $\mathrm{G} \alpha_{0 / i}$ and $\mathrm{G} \alpha_{\mathrm{s}}$ signaling function in parallel with the MSP/Eph receptor to control meiotic diapause in C. elegans. Curr. Biol. 16, 1257-1268. Abstract Article

Guo, M., Wu, T.H., Song, Y.X., Ge, M.H., Su, C.M., Niu, W.P., Li, L.L., Xu, Z.J., Ge, C.L., Al-Mhanawi., M.T., $\mathrm{Wu}$, S.P., and Wu, Z.X. (2015). Reciprocal inhibition between sensory ASH and ASI neurons modulates nociception and avoidance in Caenorhabditis elegans. Nat. Commun. 6, 5655. Abstract Article

Gürel, G., Gustafson, M.A., Pepper, J.S., Horvitz, H.R., and Koelle, M.R. (2012). Receptors and other signaling proteins required for serotonin control of locomotion in Caenorhabditis elegans. Genetics 192, 1359-1371. Abstract Article

Hajdu-Cronin, Y.M., Chen, W.J., Patikoglou, G., Koelle, M.R., and Sternberg, P.W. (1999). Antagonism between $\mathrm{G}_{0} \alpha$ and $\mathrm{G}_{\mathrm{q}} \alpha$ in Caenorhabditis elegans: the RGS protein EAT-16 is necessary for $\mathrm{G}_{0} \alpha$ signaling and regulates $\mathrm{G}_{0} \alpha$ activity. Genes Dev. 3, 1780-1793. Abstract Article

Hall, R.A. (2004). $\beta$-adrenergic receptors and their interacting proteins. Semin. Cell Dev. Biol. 15, 281-288. Abstract Article

Hamdan, F.F., Ungrin, M.D., Abramovitz, M., and Ribeiro, P. (1999). Characterization of a novel serotonin receptor from Caenorhabditis elegans: cloning and expression of two splice variants. J. Neurochem. 72, 1372-1383. Abstract Article

Hapiak, V.M., Hobson, R.J., Hughes, L., Smith, K., Harris, G., Condon, C., Komuniecki, P., and Komuniecki, R.W. (2009). Dual excitatory and inhibitory serotonergic inputs modulate egg laying in Caenorhabditis elegans. Genetics 181, 153-163. Abstract Article

Hapiak, V., Summers, P., Ortega, A., Law, W.J., Stein, A., and Komuniecki, R. (2013). Neuropeptides amplify and focus the monoaminergic inhibition of nociception in Caenorhabditis elegans. J. Neurosci. 33, 14107-14116. Abstract Article

Harris, G.P., Hapiak, V.M., Wragg, R.T., Miller, S.B., Hughes, L.J., Hobson, R.J., Steven, R, Bamber, B., and Komuniecki, R.W. (2009). Three distinct amine receptors operating at different levels within the locomotory circuit are each essential for the serotonergic modulation of chemosensation in Caenorhabditis elegans. J. Neurosci. 29, 1446-1456. Abstract Article

Harris, G., Korchnak, A., Summers, P., Hapiak, V., Law, W.J., Stein, A.M., Komuniecki, P., and Komuniecki, R. (2011). Dissecting the serotonergic food signal stimulating sensory-mediated aversive behavior in C. elegans. PLoS One. 6, e21897. Abstract Article

Harris, G., Mills, H., Wragg, R., Hapiak, V., Castelletto, M., Korchnak, A., and Komuniecki, R.W. (2010). The monoaminergic modulation of sensory-mediated aversive responses in Caenorhabditis elegans requires glutamatergic/peptidergic cotransmission. J. Neurosci. 30, 7889-7899. Abstract Article

Hendricks, M., Ha, H., Maffey, N., and Zhang, Y. (2012). Compartmentalized calcium dynamics in a C. elegans interneuron encode head movement. Nature 487, 99-103. Abstract Article

Hepler, J.R., and Gilman, .AG. (1992). G proteins. Trends Biochem. Sci. 17, 383-387. Abstract Article

Herlitze, S., Garcia, D.E., Mackie, K., Hille, B., Scheuer, T., and Catterall, W.A. (1996). Modulation of Ca ${ }^{2+}$ channels by G-protein $\beta \gamma$ subunits. Nature 380, 258-262. Abstract Article

Hess, H.A., Röper, J.C., Grill, S.W., and Koelle, M.R. (2004). RGS-7 completes a receptor-independent heterotrimeric $\mathrm{G}$ protein cycle to asymmetrically regulate mitotic spindle positioning in C. elegans. Cell 119, 209-218. Abstract Article

Hiley, E., McMullan, R., and Nurrish, S.J. (2006). The Go $\alpha_{12}$-RGS RhoGEF-RhoA signaling pathway regulates neurotransmitter release in C. elegans. EMBO J. 25, 5884-5895. Abstract Article 
Hobert O. The neuronal genome of Caenorhabditis elegans (August 13, 2013), WormBook, ed. The C. elegans Research Community, WormBook, doi/10.1895/wormbook.1.161.1, http://www.wormbook.org. Abstract Article

Hobson, R.J., Geng, J., Gray, A.D., and Komuniecki, R.W. (2003). SER-7b, a constitutively active G $\alpha_{\text {s }}$ coupled 5-HT7-like receptor expressed in the Caenorhabditis elegans M4 pharyngeal motorneuron. J. Neurochem. 87, 22-29. Abstract Article

Hobson, R.J., Hapiak, V.M., Xiao, H., Buehrer, K.L., Komuniecki, P.R., and Komuniecki, R.W. (2006). SER-7, a Caenorhabditis elegans 5-HT7-like receptor, is essential for the 5-HT stimulation of pharyngeal pumping and egg laying. Genetics 172, 159-169. Abstract Article

Hofler, C., and Koelle, M.R. (2011). AGS-3 alters Caenorhabditis elegans behavior after food deprivation via RIC-8 activation of the neural G protein G $\alpha_{\text {o. }}$ J. Neurosci. 31, 11553-11562. Abstract Article

Hofler, C., and Koelle, M.R. (2012). The G protein regulator AGS-3 allows C. elegans to alter behaviors in response to food deprivation. Worm 1, 56-60. Abstract Article

Hoyer, D., and Bartfai, T. (2012). Neuropeptides and neuropeptide receptors: drug targets, and peptide and non-peptide ligands: a tribute to Prof. Dieter Seebach. Chem. Biodivers. 9, 2367-2387. Abstract Article

Hu, Z., Pym, E.C., Babu, K., Vashlishan Murray, A.B., and Kaplan, J.M. (2011). A neuropeptide-mediated stretch response links muscle contraction to changes in neurotransmitter release. Neuron 71, 92-102. Abstract Article

Hu, Z., Vashlishan-Murray, A.B., and Kaplan, J.M. (2015). NLP-12 engages different UNC-13 proteins to potentiate tonic and evoked release. J. Neurosci. 35, 1038-1042. Abstract Article

Hwang, J.M., Chang, D.J., Kim, U.S., Lee, Y.S., Park, Y.S., Kaang, B.K., and Cho, N.J. (1999). Cloning and functional characterization of a Caenorhabditis elegans muscarinic acetylcholine receptor. Receptors Channels 6, 415-424. Abstract Article

Jafari, G., Xie, Y., Kullyev, A., Liang, B., and Sze, J.Y. (2011). Regulation of extrasynaptic 5-HT by serotonin reuptake transporter function in 5-HT-absorbing neurons underscores adaptation behavior in Caenorhabditis elegans. J. Neurosci. 15, 8948-8957. Abstract Article

James, D.J., and Martin, T.F. (2013). CAPS and Munc13: CATCHRs that SNARE vesicles. Front. Endocrinol. 4, 187. Abstract Article

Jansen, G., Thijssen, K.L., Werner, P., van der Horst, M., Hazendonk, E., and Plasterk R.H. (1999). The complete family of genes encoding G proteins of Caenorhabditis elegans. Nat. Genet. 21, 414-419. Abstract Article

Jansen, G., Weinkove, D., and Plasterk, R.H. (2002). The G-protein $\gamma$ subunit gpc-1 of the nematode C. elegans is involved in taste adaptation. EMBO J. 21, 986-994. Abstract Article

Janssen, T., Husson, S.J., Lindemans, M., Mertens, I., Rademakers, S., Ver Donck, K., Geysen, J., Jansen, G., and Schoofs, L. (2008). Functional characterization of three $G$ protein-coupled receptors for pigment dispersing factors in Caenorhabditis elegans. J. Biol. Chem. 283, 15241-15239. Abstract Article

Joffe, M.E., Grueter, C.A., and Grueter, B.A. (2014). Biological substrates of addiction. Wiley Interdiscip. Rev. Cogn. Sci. 5, 151-171. Abstract Article

Jorgensen, E.M. GABA (August 31, 2005), WormBook, ed. The C. elegans Research Community, WormBook, doi/10.1895/wormbook.1.14.1, http://www.wormbook.org. Abstract Article

Jorgenson, L.A., Newsome, W.T., Anderson, D.J., Bargmann. C.I., Brown, E.N., Deisseroth, K., Donoghue, J.P., Hudson, K.L., Ling, G.S., MacLeish, P.R., et al. (2015). The BRAIN Initiative: developing technology to catalyse neuroscience discovery. Philos. Trans. R. Soc. Lond. B Biol. Sci. 370, pii: 20140164. Abstract Article

Jose, A.M., and Koelle, M.R. (2005). Domains, amino acid residues, and new isoforms of Caenorhabditis elegans diacylglycerol kinase 1 (DGK-1) important for terminating diacylglycerol signaling in vivo. J. Biol. Chem. 280, 2730-2736. Abstract Article 
Jose, A.M., Bany, I.A., Chase, D.L., and Koelle, M.R. (2007). A specific subset of transient receptor potential vanilloid-type channel subunits in Caenorhabditis elegans endocrine cells function as mixed heteromers to promote neurotransmitter release. Genetics 175, 93-105. Abstract Article

Kadamur, G., and Ross, E.M. (2013). Mammalian phospholipase C. Annu. rev. Physiol. 75, 127-154. Abstract Article

Kandel E.R. (2004). The molecular biology of memory storage: a dialog between genes and synapses. Biosci. Rep. 24, 475-522. Abstract Article

Kandel, E.R. (2012). The molecular biology of memory: cAMP, PKA, CRE, CREB-1, CREB-2, and CPEB. Mol. Brain. 5, 14. Abstract Article

Kang, C., and Avery, L. (2009). Systemic regulation of starvation response in Caenorhabditis elegans. Genes Dev. 23, 12-17. Abstract Article

Kanner, B.I., and Zomot, E. (2008). Sodium-coupled neurotransmitter transporters. Chem. Rev. 108, 1654-1668. Abstract Article

Katritch, V., Cherezov, V., and Stevens, R.C. (2013). Structure-function of the G protein-coupled receptor superfamily. Annu. Rev. Pharmacol. Toxicol. 53, 531-556. Abstract Article

Kauffman, A.L., Ashraf, J.M., Corces-Zimmerman, M.R., Landis, J.N., and Murphy, C.T. (2010). Insulin signaling and dietary restriction differentially influence the decline of learning and memory with age. PLoS Biol. 8, e1000372. Abstract Article

Kaupmann, K., Malitschek, B., Schuler, V., Heid, J., Froestl, W., Beck, P., Mosbacher, J., Bischoff, S., Kulik, A., Shigemoto, R., et al. (1998). GABAв-receptor subtypes assemble into functional heteromeric complexes. Nature 396, 683-687. Abstract Article

Keating, C.D., Kriek, N., Daniels, M., Ashcroft, N.R., Hopper, N.A., Siney, E.J., Holden- Dye, L., and Burke, J.F. (2003). Whole-genome analysis of $60 \mathrm{G}$ protein-coupled receptors in Caenorhabditis elegans by gene knockout with RNAi. Curr. Biol. 13, 1715-1720. Abstract Article

Khan, S.M., Sleno, R., Gora, S., Zylbergold, P., Laverdure, J.P., Labbé, J.C., Miller, G.J., and Hébert, T.E. (2013). The expanding roles of $\mathrm{G} \beta \gamma$ subunits in $\mathrm{G}$ protein-coupled receptor signaling and drug action. Pharmacol. Rev. 65, 545-577. Abstract Article

Kida, S., Josselyn, S.A., Peña de Ortiz, S., Kogan, J.H., Chevere, I., Masushige, S., and Silva, A.J. (2002). CREB required for the stability of new and reactivated fear memories. Nat. Neurosci. 5, 348-355. Abstract Article

Kimura, K.D., Fujita, K., and Katsura, I. (2010). Enhancement of odor avoidance regulated by dopamine signaling in Caenorhabditis elegans. J. Neurosci. 30, 16365-16375. Abstract Article

Kindt, K.S., Quast, K.B., Giles, A.C., De, S., Hendrey, D., Nicastro, I., Rankin, C.H., and Schafer, W.R. (2007). Dopamine mediates context-dependent modulation of sensory plasticity in C. elegans. Neuron 55, 662-676. Abstract Article

Kobilka. B. (2013). The Structural Basis of G-Protein-Coupled Receptor Signaling (Nobel Lecture). Angew. Chem. Int. Ed. Engl. 52, 6380-6288. Abstract Article

Koelle, M.R., and Horvitz, H.R. (1996). EGL-10 regulates G protein signaling in the C. elegans nervous system and shares a conserved domain with many mammalian proteins. Cell 84, 115-125. Abstract Article

Kohout, T.A., and Lefkowitz, R.J. (2003). Regulation of G protein-coupled receptor kinases and arrestins during receptor desensitization. Mol. Pharmacol. 63, 9-18. Abstract Article

Komuniecki, R.W., Hobson, R.J., Rex, E.B., Hapiak, V.M., and Komuniecki, P.R. (2004). Biogenic amine receptors in parasitic nematodes: what can be learned from Caenorhabditis elegans? Mol. Biochem. Parasitol. 137, 1-11. Abstract Article 
Korswagen, H.C., Park, J.H., Ohshima, Y., and Plasterk, R.H. (1997). An activating mutation in a Caenorhabditis elegans $\mathrm{G}_{\mathrm{s}}$ protein induces neural degeneration. Genes Dev. 11, 1493-1503. Abstract Article

Krebs, E.G. (1992). Protein Phosphorylation and Cellular Regulation, I. In Nobel Lectures, Physiology or Medicine 1991-1995. N. Ringertz, ed. (Singapore: World Scientific Publishing Co.), pp. 72-89. Abstract Article

Kruse, A.C., Kobilka, B.K., Gautam, D., Sexton, P.M., Christopoulos, A., and Wess. J. (2014). Muscarinic acetylcholine receptors: novel opportunities for drug development. Nat. Rev. Drug Discov. 13, 549-560. Abstract Article

Kubiak, T.M., Larsen, M.J., Nulf, S.C., Zantello, M.R., Burton, K.J., Bowman, J.W., Modric, T., and Lowery, D.E. (2003). Differential activation of "social" and "solitary" variants of the Caenorhabditis elegans G protein-coupled receptor NPR-1 by its cognate ligand AF9. J. Biol. Chem. 278, 33724-33729. Abstract Article

Kullyev, A., Dempsey, C.M, Miller, S., Kuan, C.J., Hapiak, V.M., Komuniecki, R.W., Griffin,, C.T., and Sze, J.Y. (2010). A genetic survey of fluoxetine action on synaptic transmission in Caenorhabditis elegans. Genetics 186, 929-941. Abstract Article

Kuromi, H., and Kidokoro, Y. (2000). Tetanic stimulation recruits vesicles from reserve pool via a cAMP-mediated process in Drosophila synapses. Neuron 27, 133-143. Abstract Article

Lackner, M.R., Nurrish, S.J., and Kaplan, J.M. (1999). Facilitation of synaptic transmission by EGL-30 $\mathrm{G}_{q} \alpha$ and EGL-8 PLC $\beta$ : DAG binding to UNC-13 is required to stimulate acetylcholine release. Neuron 24, 335-346. Abstract Article

Lambright, D.G., Noel, J.P., Hamm, H.E., and Sigler, P.B. (1994). Structural determinants for activation of the $\alpha$-subunit of a heterotrimeric G protein. Nature 369, 621-628. Abstract Article

Lee, Y.S., Park, Y.S., Nam, S., Suh, S.J., Lee, J., Kaang, B.K., and Cho, N.J. (2000). Characterization of GAR-2, a novel G protein-linked acetylcholine receptor from Caenorhabditis elegans. J. Neurochem. 75, 1800-1809. Abstract Article

Lefkowitz, R.J. (2013). A Brief History of G-Protein Coupled Receptors (Nobel Lecture). Angew. Chem. Int. Ed. Engl. 52, 6366-6378. Abstract Article

Leiser, S.F., Miller, H., Rossner, R., Fletcher, M., Leonard, A., Primitivo, M., Rintala, N., Ramos, F.J., Miller, D.L., and Kaeberlein, M. (2015). Cell nonautonomous activation of flavin-containing monooxygenase promotes longevity and health span. Science 350, 1375-1378. Abstract Article

Lemoine, D., Jiang, R., Taly, A., Chataigneau, T., Specht, A., and Grutter, T. (2012). Ligand-gated ion channels: new insights into neurological disorders and ligand recognition. Chem. Rev. 112, 6285-6318. Abstract Article

Li, C. and Kim, K. Neuropeptides (April 27, 2008) WormBook, ed. The C. elegans Research Community, WormBook, doi/10.1895/wormbook.1.142.1, http://www.wormbook.org. Abstract Article

Li, C., and Kim, K. (2010). Neuropeptide gene families in Caenorhabditis elegans. Adv. Exp. Med. Biol. 692, 98-137. Abstract Article

Li, G., and Zhang, X.C. (2004). GTP hydrolysis mechanism of Ras-like GTPases. J. Mol. Biol. 340, 921-932. Abstract Article

Li, Y., Zhao, Y., Huang, X., Lin, X., Guo, Y., Wang, D., Li, C., and Wang, D. (2013). Serotonin control of thermotaxis memory behavior in nematode Caenorhabditis elegans. PLoS One 8, e77779. Abstract Article

Liu, Y., LeBoeuf, B., and Garcia, L.R. (2007). G $\alpha_{q}$-coupled muscarinic acetylcholine receptors enhance nicotinic acetylcholine receptor signaling in Caenorhabditis elegans mating behavior. J. Neurosci. 27, 1411-1421. Abstract Article

Love, T.M. (2014). Oxytocin, motivation and the role of dopamine. Pharmacol. Biochem. Behav. 119, 49-60. Abstract Article 
Lutz, S., Shankaranarayanan, A., Coco, C., Ridilla, M., Nance, M.R., Vettel, C., Baltus, D., Evelyn, C.R., Neubig, R.R., Wieland, T., and Tesmer, J.J. (2007). Structure of $\mathrm{G} \alpha_{\mathrm{q}}$-p63RhoGEF-RhoA complex reveals a pathway for the activation of RhoA by GPCRs. Science 318, 1923-1927. Abstract Article

Marder, E. (2012). Neuromodulation of neuronal circuits: back to the future. Neuron 76, 1-11. Abstract Article

Matsuki, M., Kunitomo, H., and Iino, Y. (2006). Go $\alpha$ regulates olfactory adaptation by antagonizing Gq $\alpha$-DAG signaling in Caenorhabditis elegans. Proc. Natl. Acad. Sci. U. S. A. 103, 1112-1117. Abstract Article

McDonald, P.W., Hardie, S.L., Jessen, T.N., Carvelli, L., Matthies, D.S., and Blakely, R.D. (2007). Vigorous motor activity in Caenorhabditis elegans requires efficient clearance of dopamine mediated by synaptic localization of the dopamine transporter DAT-1. J. Neurosci. 27, 14216-14227. Abstract Article

McMullan, R., Hiley, E., Morrison, P., Nurrish, S.J. (2006). Rho is a presynaptic activator of neurotransmitter release at pre-existing synapses in C. elegans. Genes Dev. 20, 65-76. Abstract Article

Mendel, J.E., Korswagen, H.C., Liu, K.S., Hajdu-Cronin, Y.M., Simon, M.I., Plasterk, R.H., and Sternberg, P.W. (1995). Participation of the protein Go in multiple aspects of behavior in C. elegans. Science 267, 1652-1655. Abstract Article

Merighi, A., Salio, C., Ferrini, F., and Lossi, L. (2011). Neuromodulatory function of neuropeptides in the normal CNS. J. Chem. Neuroanat. 42, 276-287. Abstract Article

Mersha, M., Formisano, R., McDonald, R., Pandey, P., Tavernarakis, N., and Harbinder, S. (2013). GPA-14, a Go $\alpha_{i}$ subunit mediates dopaminergic behavioral plasticity in C. elegans. Behav. Brain Funct. 9, 16. Abstract Article

Mertens, I., Vandingenen, A., Meeusen, T., De Loof, A., and Schoofs, L. (2004). Postgenomic characterization of G-protein-coupled receptors. Pharmacogenomics 5, 657-672. Abstract Article

Miller, K.G., and Rand, J.B. (2000). A role for RIC-8 (Synembryn) and GOA-1 (Go $\alpha$ ) in regulating a subset of centrosome movements during early embryogenesis in Caenorhabditis elegans. Genetics 156, 1649-1660. Abstract Article

Miller, K.G., Alfonso, A., Nguyen, M., Crowell, J.A., Johnson, C.D., and Rand, J.B. (1996). A genetic selection for Caenorhabditis elegans synaptic transmission mutants. Proc. Natl. Acad. Sci. U. S. A. 93, 12593-12598. Abstract Article

Miller, K.G., Emerson, M.D., and Rand, J.B. (1999). Go $\alpha$ and diacylglycerol kinase negatively regulate the $\mathrm{G}_{q} \alpha$ pathway in C. elegans. Neuron. 24, 323-233. Abstract Article

Miller, K.G, Emerson, M.D., McManus, J.R., and Rand, J.B. (2000). RIC-8 (Synembryn): a novel conserved protein that is required for $\mathrm{G}_{q} \alpha$ signaling in the C. elegans nervous system. Neuron 27, 289-299. Abstract Article

Mills, H., Wragg, R., Hapiak, V., Castelletto, M., Zahratka, J., Harris, G., Summers, P., Korchnak, A., Law, W., Bamber, B., and Komuniecki, R. (2012). Monoamines and neuropeptides interact to inhibit aversive behaviour in Caenorhabditis elegans. EMBO J. 31, 667-678. Abstract Article

Min, D.S., Cho, N.J., Yoon, S.H., Lee, Y.H., Hahn, S.J., Lee, K.H., Kim, M.S., and Jo, Y.H. (2000). Phospholipase $\mathrm{C}$, protein kinase $\mathrm{C}, \mathrm{Ca}^{2+}$ /calmodulin-dependent protein kinase II, and tyrosine phosphorylation are involved in carbachol-induced phospholipase D activation in Chinese hamster ovary cells expressing muscarinic acetylcholine receptor of Caenorhabditis elegans. J. Neurochem. 75, 274-281. Abstract Article

Moorman, C., and Plasterk, R.H. (2002). Functional characterization of the adenylyl cyclase gene $s g s-1$ by analysis of a mutational spectrum in Caenorhabditis elegans. Genetics. 161, 133-142. Abstract Article

Moreira, I.S. (2014). Structural features of the G-protein/GPCR interactions. Biochim. Biophys. Acta 1840, 16-33. Abstract Article

Murakami, H., and Murakami S. (2007). Serotonin receptors antagonistically modulate Caenorhabditis elegans longevity. Aging Cell 6, 483-438. Abstract Article 
Näsman, J., Kukkonen, J.P., Holmqvist, T., and Akerman, K.E. (2002). Different roles for $\mathrm{G}_{\mathrm{i}}$ and Go proteins in modulation of adenylyl cyclase type-2 activity. J. Neurochem. 83, 1252-1261. Abstract Article

Nelson, J.C., and Colón-Ramos, D.A. (2012). Serotonergic neurosecretory synapse targeting is controlled by netrin-releasing guidepost neurons in Caenorhabditis elegans. J. Neurosci. 33, 1366-1376. Abstract Article

Noel, J.P., Hamm, H.E., and Sigler, P.B. (1993). The $2.2 \AA$ crystal structure of transducin- $\alpha$ complexed with GTP $\gamma$ S. Nature 366, 654-663. Abstract Article

Nurrish, S., Ségalat, L., and Kaplan, J.M. (1999). Serotonin inhibition of synaptic transmission: Goo decreases the abundance of UNC-13 at release sites. Neuron 24, 231-242. Abstract Article

Okada, T., Kajimoto, T., Jahangeer, S., and Nakamura, S. (2009). Sphingosine kinase/sphingosine 1-phosphate signalling in central nervous system. Cell Signal. 21, 7-13. Abstract Article

Olde, B., and McCombie W.R. (1997). Molecular cloning and functional expression of a serotonin receptor from Caenorhabditis elegans. J. Mol. Neurosci. 8, 53-62. Abstract Article

Omura, D.T., Clark, D.A., Samuel, A.D., and Horvitz, H.R. (2012). Dopamine signaling is essential for precise rates of locomotion by C. elegans. PLoS One 7, e38649. Abstract Article

Palmitessa, A., Hess, H.A., Bany, I.A., Kim, Y.M., Koelle, M.R., and Benovic, J.L. (2005). Caenorhabditus elegans arrestin regulates neural $\mathrm{G}$ protein signaling and olfactory adaptation and recovery. J. Biol. Chem. 280, 24649-24662. Abstract Article

Pandey, P., and Harbinder, S. (2012). The Caenorhabditis elegans D2-like dopamine receptor DOP-2 physically interacts with GPA-14, a G $\alpha_{i}$ subunit. J. Mol. Signal. 7, 3. Abstract Article

Park, D., O’Doherty, I., Somvanshi, R.K., Bethke, A., Schroeder, F.C., Kumar, U., and Riddle, D.L. (2012). Interaction of structure-specific and promiscuous G-protein-coupled receptors mediates small-molecule signaling in Caenorhabditis elegans. Proc. Natl. Acad. Sci. U. S. A. 109, 9917-9922. Abstract Article

Park, J.H., Ohshima, S., Tani, T., Ohshima, Y. (1997). Structure and expression of the gsa-1 gene encoding a G protein $\alpha_{s}$ subunit in C. elegans. Gene 194, 183-190. Abstract Article

Park, Y.S., Cho, T.J., and Cho, N.J. (2006). Stimulation of cyclic AMP production by the Caenorhabditis elegans muscarinic acetylcholine receptor GAR-3 in Chinese hamster ovary cells. Arch. Biochem. Biophys. 450, 203-207. Abstract Article

Park, Y.S., Kim, S., Shin, Y., Choi, B., and Cho, N.J. (2003). Alternative splicing of the muscarinic acetylcholine receptor GAR-3 in Caenorhabditis elegans. Biochem. Biophys. Res. Commun. 308, 961-965. Abstract Article

Park, Y.S., Lee, Y.S., Cho, N.J., and Kaang, B.K. (2000). Alternative splicing of gar-1, a Caenorhabditis elegans G-protein-linked acetylcholine receptor gene. Biochem. Biophys. Res. Commun. 268, 354-358. Abstract Article

Patikoglou, G.A., and Koelle, M.R. (2002). An N-terminal region of Caenorhabditis elegans RGS proteins EGL-10 and EAT-16 directs inhibition of $\mathrm{G} \alpha_{\mathrm{o}}$ versus $\mathrm{G} \alpha_{\mathrm{q}}$ signaling. J. Biol. Chem. 277, 47004-47013. Abstract Article

Perazzona, B., Isabel, G., Preat, T., and Davis, R.L. (2004). The role of cAMP response element-binding protein in Drosophila long-term memory. J. Neurosci. 24, 8823-8828. Abstract Article

Pereira, L., Kratsios, P., Serrano-Saiz, E., Sheftel, H., Mayo, A.E., Hall, D.H., White, J.G., LeBoeuf. B., Garcia, L.R., Alon, U., and Hobert, O. (2015). A cellular and regulatory map of the cholinergic nervous system of $C$. elegans. eLife 4, pii: e12432. Abstract Article

Pereira, S., and van der Kooy, D. (2012). Two forms of learning following training to a single odorant in Caenorhabditis elegans AWC neurons. J. Neurosci. 32, 9035-9044. Abstract Article 
Perez-Mansilla, B, and Nurrish, S. (2009). A network of G-protein signaling pathways control neuronal activity. Adv. Genet. 65, 145-192. Abstract Article

Peterson, Y.K., Bernard, M.L., Ma, H., Hazard, S. III, Graber, S.G., and Lanier, S.M. (2000). Stabilization of the GDP-bound conformation of Gi $\alpha$ by a peptide derived from the G-protein regulatory motif of AGS3. J. Biol. Chem. 275, 33193-33196. Abstract Article

Petrascheck, M., Ye, X., and Buck, L.B. (2007). An antidepressant that extends lifespan in adult Caenorhabditis elegans. Nature 450, 553-556. Abstract Article

Peymen, K., Watteyne, J., Frooninckx, L., Schoofs, L., and Beets, I. (2014). The FMRFamide-like peptide family in nematodes. Front. Endocrinol. 5, 90. Abstract Article

Pirri, J.K., McPherson, A.D., Donnelly, J.L., Francis, M.M., and Alkema, M.J. (2009). A tyramine-gated chloride channel coordinates distinct motor programs of a Caenorhabditis elegans escape response. 62, 526-538. Abstract Article

Pocock, R., and Hobert, O. (2010). Hypoxia activates a latent circuit for processing gustatory information in $C$. elegans. Nat. Neurosci. 13, 610-614. Abstract Article

Poole, R.J., Bashllari, E., Cochella, L., Flowers, E.B., and Hobert, O. (2011). A genome-wide RNAi screen for factors involved in neuronal specification in Caenorhabditis elegans. PLoS Genet. 7, e1002109. Abstract Article

Porter, M.Y., and Koelle, M.R. (2009). Insights into RGS protein function from studies in Caenorhabditis elegans. Prog. Mol. Biol. Transl. Sci. 86, 15-47. Abstract Article

Pytliak, M., Vargová, V., Mechírová, V., and Felšöci, M. (2011). Serotonin receptors-from molecular biology to clinical applications. Physiol. Res. 60, 15-25. Abstract Article

Rand, J.B. Acetylcholine (January 30, 2007), WormBook, ed. The C. elegans Research Community, WormBook, doi/10.1895/wormbook.1.131.1, http://www.wormbook.org. Abstract Article

Rasmussen, S.G., DeVree, B.T., Zou, Y., Kruse, A.C., Chung, K.Y., Kobilka, T.S., Thian, F.S., Chae, P.S., Pardon, E., Calinski, D., et al. (2011). Crystal structure of the $\beta_{2}$ adrenergic receptor-Gs protein complex. Nature 477, 549-555. Abstract Article

Reuveny, E., Slesinger, P.A., Inglese, J., Morales, J.M., Iñiguez-Lluhi, J.A., Lefkowitz, R.J., Bourne, H.R., Jan, Y.N., and Jan, L.Y. (1994). Activation of the cloned muscarinic potassium channel by G protein $\beta \gamma$ subunits. Nature 370, 143-146. Abstract Article

Rex, E., and Komuniecki, R.W. (2002). Characterization of a tyramine receptor from Caenorhabditis elegans. J. Neurochem. 82, 1352-1359. Abstract Article

Rex, E., Hapiak, V., Hobson, R., Smith, K., Xiao, H., and Komuniecki, R. (2005). TYRA-2 (F01E11.5): a Caenorhabditis elegans tyramine receptor expressed in the MC and NSM pharyngeal neurons. J. Neurochem. 94, 181-189 Abstract Article

Rex, E., Molitor, S.C., Hapiak, V., Xiao, H., Henderson, M., and Komuniecki, R. (2004). Tyramine receptor (SER-2) isoforms are involved in the regulation of pharyngeal pumping and foraging behavior in Caenorhabditis elegans. J. Neurochem. 91, 1104-1115. Abstract Article

Reynolds, N.K., Schade, M.A., and Miller, K.G. (2005). Convergent, RIC-8-dependent G $\alpha$ signaling pathways in the Caenorhabditis elegans synaptic signaling network. Genetics 169, 651-670. Abstract Article

Rhee, J.S., Betz, A., Pyott, S., Reim, K., Varoqueaux, F., Augustin, I., Hesse, D., Robatzek, M., Niacaris, T., Steger, K., Avery, L., and Thomas, J.H. (2001). $\beta$ phorbol ester- and diacylglycerol-induced augmentation of transmitter release is mediated by Munc13s and not by PKCs. Cell 108, 121-133. Abstract Article

Ringstad, N., and Horvitz, H.R. (2008). FMRFamide neuropeptides and acetylcholine synergistically inhibit egg-laying by C. elegans. Nat. Neurosci. 11, 1168-1176. Abstract Article 
Robatzek, M., Niacaris, T., Steger, K., Avery, L., and Thomas, J.H. (2001). eat-11 encodes GPB-2, a Gß5 ortholog that interacts with $\mathrm{G}_{0} \alpha$ and $\mathrm{G}_{\mathrm{q}} \alpha$ to regulate C. elegans behavior. Curr. Biol. 11, 288-293. Abstract Article

Rodbell, M. (1994). Signal Transduction: Evolution of an Idea. In Nobel Lectures - Physiology or Medicine 1991-1995. N. Ringertz, ed. (Singapore: World Scientific Publishing Co.), pp. 220-237. Abstract Article

Rogers, C., Reale, V., Kim, K., Chatwin, H., Li, C., Evans, P., and de Bono, M. (2003). Inhibition of Caenorhabditis elegans social feeding by FMRFamide-related peptide activation of NPR-1. Nat. Neurosci. 6, 1178-1185. Abstract Article

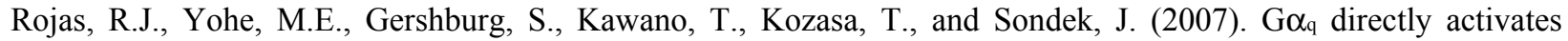
p63RhoGEF and Trio via a conserved extension of the Dbl homology-associated pleckstrin homology domain. J. Biol. Chem. 282, 29201-29210. Abstract Article

Rose, L. and Gönczy, P. Polarity establishment, asymmetric division and segregation of fate determinants in early $C$. elegans embryos (December 30, 2014) WormBook, ed. The C. elegans Research Community, WormBook, doi/10.1895/wormbook.1.30.2, http://www.wormbook.org. Abstract Article

Ross, E.M. (2014). G protein-coupled receptors: Multi-turnover GDP/GTP exchange catalysis on heterotrimeric G proteins. Cell. Logist. 4, e29391. Abstract Article

Sabatini, B.L., and Regehr, W.G. (1996). Timing of neurotransmission at fast synapses in the mammalian brain. Nature 384, 170-172. Abstract Article

Sánchez-Fernández, G., Cabezudo, S., García-Hoz, C., Benincá, C., Aragay, A.M., Mayor, F. Jr., and Ribas, C. (2014). G $\alpha_{q}$ signalling: the new and the old. Cell Signal. 26, 833-848. Abstract Article

Sanyal, S., Wintle, R.F., Kindt, K.S., Nuttley, W.M., Arvan, R., Fitzmaurice, P., Bigras, E., Merz, D.C., Hébert, T.E., van der Kooy, D., et al. (2004). Dopamine modulates the plasticity of mechanosensory responses in Caenorhabditis elegans. EMBO J. 23, 473-482. Abstract Article

Sawin, E.R., Ranganathan, R., and Horvitz, H.R. (2000). C. elegans locomotory rate is modulated by the environment through a dopaminergic pathway and by experience through a serotonergic pathway. Neuron 26, 619-631. Abstract Article

Schade, M.A., Reynolds, N.K., Dollins, C.M., and Miller, K.G. (2005). Mutations that rescue the paralysis of Caenorhabditis elegans ric-8 (synembryn) mutants activate the $\mathrm{G} \alpha_{\text {s }}$ pathway and define a third major branch of the synaptic signaling network. Genetics 169, 631-649. Abstract Article

Schafer, W.F. (2006). Genetics of egg-laying in worms. Annu. Rev. Genet. 40, 487-509. Abstract Article

Schultheis, C., Brauner, M., Liewald, J.F., and Gottschalk, A. (2011). Optogenetic analysis of GABAв receptor signaling in Caenorhabditis elegans motor neurons. J. Neurophysiol. 106, 817-827. Abstract Article

Ségalat, L., Elkes, D.A., and Kaplan, J.M. (1995). Modulation of serotonin-controlled behaviors by Go in Caenorhabditis elegans. Science 267, 1648-1651. Abstract Article

Sellings, L., Pereira, S., Qian, C., Dixon-McDougall, T., Nowak, C., Zhao, B., Tyndale, R.F., and van der Kooy. D. (2013). Nicotine-motivated behavior in Caenorhabditis elegans requires the nicotinic acetylcholine receptor subunits acr-5 and acr-15. Eur. J. Neurosci. 37, 743-756. Abstract Article

Serrano-Saiz, E., Poole, R.J., Felton, T., Zhang, F., De La Cruz, E.D., and Hobert, O. (2013). Modular control of glutamatergic neuronal identity in C. elegans by distinct homeodomain proteins. Cell 155, 659-673. Abstract Article

Siderovski, D.P., Diversé-Pierluissi, M.A., and De Vries, L. (1999). The GoLoco motif: a Go $\alpha_{\text {i/o }}$ binding motif and potential guanine-nucleotide exchange factor. Trends Biochem. Sci. 24, 340-341. Abstract Article

Sieburth, D., Ch'ng, Q., Dybbs, M., Tavazoie, M., Kennedy, S., Wang, D., Dupuy, D., Rual, J.F., Hill, D.E., Vidal, M., Ruvkun, G., and Kaplan, J.M. (2005) Systematic analysis of genes required for synapse structure and function. Nature 436, 510-517. Abstract Article 
Sieburth, D., Madison, J.M., and Kaplan, J.M. (2007). PKC-1 regulates secretion of neuropeptides. Nat. Neurosci. 10, 49-57. Abstract Article

Siehler, S. (2009). Regulation of RhoGEF proteins by G12/13-coupled receptors. Br. J. Pharmacol. 158, 41-49. Abstract Article

Singh, V., and Aballay, A. (2012). Endoplasmic reticulum stress pathway required for immune homeostasis is neurally controlled by arrestin-1. J. Biol. Chem. 287, 33191-33197. Abstract Article

Song, B.M., and Avery, L. (2012). Serotonin activates overall feeding by activating two separate neural pathways in Caenorhabditis elegans. J. Neurosci. 32, 1920-1931. Abstract Article

Song, B.M., Faumont, S., Lockery, S., and Avery, L. (2013). Recognition of familiar food activates feeding via an endocrine serotonin signal in Caenorhabditis elegans. eLife 2, e00329. Abstract Article

Speese, S., Petrie, M., Schuske, K., Ailion, M., Ann, K., Iwasaki, K., Jorgensen, E.M., and Martin, T.F. (2007). UNC-31 (CAPS) is required for dense-core vesicle but not synaptic vesicle exocytosis in Caenorhabditis elegans. J. Neurosci. 27, 6150-6162. Abstract Article

Spencer, W.C., McWhirter, R., Miller, T., Strasbourger, P., Thompson, O., Hillier, L.W., Waterston, R.H., and Miller, D.M. III. (2014). Isolation of specific neurons from C. elegans larvae for gene expression profiling. PLoS One. 9, e112102. Abstract Article

Srinivasan, D.G., Fisk, R.M., Xu, H., and van den Heuvel, S. (2003). A complex of LIN-5 and GPR proteins regulates $\mathrm{G}$ protein signaling and spindle function in C. elegans. Genes Dev. 17, 1225-3129. Abstract Article

Srinivasan, S., Sadegh, L., Elle, I.C., Christensen, A.G., Faergeman, N.J., and Ashrafi, K. (2008). Serotonin regulates C. elegans fat and feeding through independent molecular mechanisms. Cell Metab. 7, 533-544. Abstract Article

Stawicki, T.M., Takayanagi-Kiya, S., Zhou, K., and Jin, Y. (2013). Neuropeptides function in a homeostatic manner to modulate excitation-inhibition imbalance in C. elegans. PLoS Genet. 9, e1003472. Abstract Article

Steger, K.A., and Avery, L. (2004). The GAR-3 muscarinic receptor cooperates with calcium signals to regulate muscle contraction in the Caenorhabditis elegans pharynx. Genetics 167, 633-463. Abstract Article

Sternweis, P.C., and Robishaw, J.D. (1984). Isolation of two proteins with high affinity for guanine nucleotides from membranes of bovine brain. J. Biol. Chem. 259, 13806-13813. Abstract Article

Sugiura, M., Fuke, S., Suo, S., Sasagawa, N., Van Tol, H.H., and Ishiura. S. (2005). Characterization of a novel D2-like dopamine receptor with a truncated splice variant and a D1-like dopamine receptor unique to invertebrates from Caenorhabditis elegans. J. Neurochem. 94, 1146-1157. Abstract Article

Suh, S.J., Park, Y.S., Lee, Y.S., Cho, T.J., Kaang, B.K., and Cho, N.J. (2001). Three functional isoforms of GAR-2, a Caenorhabditis elegans G-protein-linked acetylcholine receptor, are produced by alternative splicing. Biochem. Biophys. Res. Commun. 288, 1238-1243. Abstract Article

Sun, J., Liu, Y., and Aballay, A. (2012). Organismal regulation of XBP-1-mediated unfolded protein response during development and immune activation. EMBO Rep. 13, 855-860. Abstract Article

Sun, J., Singh, V., Kajino-Sakamoto, R., Aballay, A. (2011). Neuronal GPCR controls innate immunity by regulating noncanonical unfolded protein response genes. Science 332, 729-732. Abstract Article

Sunahara, R.K., Dessauer, C.W., and Gilman, A.G. (1996). Complexity and diversity of mammalian adenylyl cyclases. Annu. Rev. Pharmacol. Toxicol. 36, 461-480. Abstract Article

Suo, S., Culotti, J.G., and Van Tol, H.H. (2009). Dopamine counteracts octopamine signalling in a neural circuit mediating food response in C. elegans. EMBO J. 28, 2437-2448. Abstract Article 
Suo, S., Kimura, Y., and Van Tol, H.H. (2006). Starvation induces cAMP response element-binding protein-dependent gene expression through octopamine- $\mathrm{G}_{q}$ signaling in Caenorhabditis elegans. J. Neurosci. 26, 10082-10090. Abstract Article

Suo, S., Sasagawa, N., and Ishiura, S. (2002). Identification of a dopamine receptor from Caenorhabditis elegans. Neurosci. Lett. 319, 13-16. Abstract Article

Suo, S., Sasagawa, N., and Ishiura, S. (2003). Cloning and characterization of a Caenorhabditis elegans D2-like dopamine receptor. J. Neurochem. 86, 869-878. Abstract Article

Sutherland, E.W. (1971). Studies on the Mechanism of Hormone Action. In Nobel Lectures, Physiology or Medicine 1971-1980, J. Lindsten, ed. (Signapore: World Scientific Publishing Co.), pp. 5-22. Abstract Article

Takesono, A., Cismowski, M.J., Ribas, C., Bernard, M., Chung, P., Hazard, S. III, Duzic, E., and Lanier, S.M. (1999) Receptor-independent activators of heterotrimeric G-protein signaling pathways. J. Biol. Chem. 274, 33202-33205. Abstract Article

Tall, G.G., Krumins, A.M., and Gilman, A.G. (2003). Mammalian Ric-8A (synembryn) is a heterotrimeric G $\alpha$ protein guanine nucleotide exchange factor. J. Biol. Chem. 278, 8356-8362 Abstract Article

Tanis, J.E., Moresco, J.J., Lindquist, R.A., and Koelle, M.R. (2008). Regulation of serotonin biosynthesis by the G proteins $\mathrm{G} \alpha_{o}$ and $\mathrm{G} \alpha_{q}$ controls serotonin signaling in Caenorhabditis elegans. Genetics 178, 157-169. Abstract Article

Taussig, R., Tang, W.J., Hepler, J.R., and Gilman, A.G. (1994). Distinct patterns of bidirectional regulation of mammalian adenylyl cyclases. J. Biol. Chem. 269, 6093-6100. Abstract Article

Tesmer, J.J., Berman, D.M., Gilman, A.G., and Sprang, S.R. (1997). Structure of RGS4 bound to AlF 4 - activated Gial: stabilization of the transition state for GTP hydrolysis. Cell 89, 251-261. Abstract Article

Tharmalingam, S., Burns, A.R., Roy, P.J., and Hampson, D.R. Orthosteric and allosteric drug binding sites in the Caenorhabditis elegans mgl-2 metabotropic glutamate receptor. Neuropharmacology 63, 667-674. Abstract Article

Thomas, C.J., Tall, G.G., Adhikari, A., and Sprang, S.R. (2008). Ric-8A catalyzes guanine nucleotide exchange on $\mathrm{G}_{\mathrm{il}}$ bound to the GPR/GoLoco exchange inhibitor AGS3. J. Biol. Chem. 283, 23150-23160. Abstract Article

Topper, S.M., Aguilar, S.C., Topper, V.Y., Elbel, E., and Pierce-Shimomura, J.T. (2014). Alcohol disinhibition of behaviors in C. elegans. PLoS One 9, e92965. Abstract Article

Trent, C., Tsung, N., and Horvitz, H.R. (1983). Egg-laying defective mutants of the nematode Caenorhabditis elegans. Genetics 104, 619-647. Abstract Article

Trudeau, L.E., Emery, D.G., and Haydon, P.G. (1996). Direct modulation of the secretory machinery underlies PKA-dependent synaptic facilitation in hippocampal neurons. Neuron 17, 789-797. Abstract Article

Tsalik, E.L., Niacaris, T., Wenick, A.S., Pau, K., Avery, L., and Hobert, O. (2003). LIM homeobox gene-dependent expression of biogenic amine receptors in restricted regions of the C. elegans nervous system. Dev. Biol. 263, 81-102. Abstract Article

Vaidya, A., Jain, S., Jain, A.K., Agrawal, A., Kashaw, S.K., Jain, S.K., and Agrawal R.K. (2013). Metabotropic glutamate receptors: a review on prospectives and therapeutic aspects. Mini Rev. Med. Chem. 13, 1967-1981. Abstract Article

Vashlishan, A.B., Madison, J.M., Dybbs, M., Bai, J., Sieburth, D., Ch'ng, Q., Tavazoie, M., and Kaplan, J.M. (2008). An RNAi screen identifies genes that regulate GABA synapses. Neuron 58, 346-361. Abstract Article

van der Linden, A.M., Moorman, C., Cuppen, E., Korswagen, H.C., and Plasterk, R.H. (2003). Hyperactivation of the G12-mediated signaling pathway in Caenorhabditis elegans induces a developmental growth arrest via protein kinase C. Curr Biol. 13, 516- 521. Abstract Article 
van der Linden, A.M., Simmer, F., Cuppen, E., Plasterk, R.H. (2001). The G-protein $\beta$-subunit GPB-2 in Caenorhabditis elegans regulates the $\mathrm{G}_{0} \alpha-\mathrm{G}_{\mathrm{q}} \alpha$ signaling network through interactions with the regulator of G-protein signaling proteins EGL-10 and EAT-16. Genetics 158, 221-235. Abstract Article

Vidal-Gadea, A., Topper, S., Young, L., Crisp, A., Kressin, L., Elbel, E., Maples, T., Brauner, M., Erbguth, K., Axelrod, A., et al. (2011). Caenorhabditis elegans selects distinct crawling and swimming gaits via dopamine and serotonin. Proc. Natl. Acad. Sci. U. S. A. 108, 17504-17509. Abstract Article

Wall, M.A., Coleman, D.E., Lee, E., Iñiguez-Lluhi, J.A., Posner, B.A., Gilman, A.G., and Sprang. S.R. (1995). The structure of the G protein heterotrimer Gi $\alpha_{1} \beta_{1} \gamma_{2}$. Cell 83, 1047-1058. Abstract Article

Wang, D., Yu, Y., Li, Y., Wang, Y., and Wang, D. (2014). Dopamine receptors antagonistically regulate behavioral choice between conflicting alternatives in C. elegans. PLoS One 9, e115985. Abstract Article

Wang, H., Girskis, K., Janssen, T., Chan, J.P., Dasgupta, K., Knowles, J.A., Schoofs, L., and Sieburth, D. (2013). Neuropeptide secreted from a pacemaker activates neurons to control a rhythmic behavior. Curr. Biol. 23, 746-754. Abstract Article

Wang, Y., Tang, L., Feng, X., Du, W., and Liu, B.F. (2011). Ethanol interferes with gustatory plasticity in Caenorhabditis elegans. Neurosci. Res. 71, 341-347. Abstract Article

Wedegaertner, P.B., Wilson, P.T., and Bourne, H.R. (1995). Lipid modifications of trimeric G proteins. J. Biol. Chem. 270, 503-506. Abstract Article

White, J.G., Southgate, E., Thomson, J.N., and Brenner, S. (1986). The structure of the nervous system of the nematode Caenorhabditis elegans. Philos. Trans. R. Soc. Lond. B Biol. Sci. 314, 1-340. Abstract Article

Whiteway, M., Hougan, L., Dignard, D., Thomas, D.Y., Bell, L., Saari, G.C., Grant, F.J., O'Hara, P., and MacKay, V.L. (1989). The STE4 and STE18 genes of yeast encode potential $\beta$ and $\gamma$ subunits of the mating factor receptor-coupled G protein. Cell 56, 467-477. Abstract Article

Wierda, K.D., Toonen, R.F., de Wit, H., Brussaard, A.B., and Verhage, M. (2007). Interdependence of PKC-dependent and PKC-independent pathways for presynaptic plasticity. Neuron 54, 275-290. Abstract Article

Williams, S.L., Lutz, S., Charlie, N.K., Vettel, C., Ailion, M., Coco, C., Tesmer, J.J., Jorgensen, E.M., Wieland, T., and Miller, K.G. (2007). Trio's Rho-specific GEF domain is the missing $G \alpha_{q}$ effector in C. elegans. Genes Dev. 21, 2731-2746. Abstract Article

Wragg, R.T., Hapiak, V., Miller, S.B., Harris, G.P., Gray, J., Komuniecki, P.R., and Komuniecki, R.W. (2007). Tyramine and octopamine independently inhibit serotonin-stimulated aversive behaviors in Caenorhabditis elegans through two novel amine receptors. J. Neurosci. 27, 13402-13412. Abstract Article

Xiao, H., Hapiak, V.M., Smith, K.A., Lin, L., Hobson, R.J., Plenefisch, J., and Komuniecki, R. (2006). SER-1, a Caenorhabditis elegans 5-HT2-like receptor, and a multi-PDZ domain containing protein (MPZ-1) interact in vulval muscle to facilitateserotonin-stimulated egg-laying. Dev. Biol. 298, 379-391. Abstract Article

Yau, D.M., Yokoyama, N., Goshima, Y., Siddiqui, Z.K., Siddiqui, S.S., and Kozasa, T. (2003). Identification and molecular characterization of the $\mathrm{G \alpha}_{12}$-Rho guanine nucleotide exchange factor pathway in Caenorhabditis elegans. Proc. Natl. Acad. Sci. U. S. A. 100, 14748-1453. Abstract Article

Yoshida, M., Oami, E., Wang, M., Ishiura, S., and Suo, S. (2014). Nonredundant function of two highly homologous octopamine receptors in food-deprivation-mediated signaling in Caenorhabditis elegans. J. Neurosci. Res. 92, 671-678. Abstract Article

Zhou, K.M., Dong, Y.M., Ge, Q., Zhu, D., Zhou, W., Lin, X.G,, Liang, T., Wu, Z.X., and Xu, T. (2007). PKA activation bypasses the requirement for UNC-31 in the docking of dense core vesicles from C. elegans neurons. Neuron 56, 657-669. Abstract Article

Zimmerman, G., and Soreq, H. (2006). Termination and beyond: acetylcholinesterase as a modulator of synaptic transmission. Cell Tissue Res. 326, 655-669. Abstract Article 
Zimmerman, J.E., Naidoo, N., Raizen, D.M., and Pack, A.I. (2008). Conservation of sleep: insights from non-mammalian model systems. Trends Neurosci. 31, 371-376. Abstract Article

Zwaal, R.R, Ahringer, J., van Luenen, H.G., Rushforth, A., Anderson, P., and Plasterk, R.H. (1996). G proteins are required for spatial orientation of early cell cleavages in C. elegans embryos. Cell 86, 619-629. Abstract Article

All WormBook content, except where otherwise noted, is licensed under a Creative SOMIERIGHISRESERVED Commons Attribution License. 